University of Florida Levin College of Law

UF Law Scholarship Repository

UF Law Faculty Publications

Faculty Scholarship

2009

Limiting Anticompetitive Government Interventions that Benefit Special Interests

D. Daniel Sokol

University of Florida Levin College of Law, sokold@law.ufl.edu

Follow this and additional works at: https://scholarship.law.ufl.edu/facultypub

Part of the Antitrust and Trade Regulation Commons, Comparative and Foreign Law Commons, and the International Trade Law Commons

Recommended Citation

D. Daniel Sokol, Limiting Anticompetitive Government Interventions that Benefit Special Interests, 17 Geo. Mason L. Rev. 119 (2009), available at http://scholarship.law.ufl.edu/facultypub/149

This Article is brought to you for free and open access by the Faculty Scholarship at UF Law Scholarship Repository. It has been accepted for inclusion in UF Law Faculty Publications by an authorized administrator of UF Law Scholarship Repository. For more information, please contact kaleita@law.ufl.edu. 


\title{
LIMITING ANTICOMPETITIVE GOVERNMENT INTERVENTIONS THAT BENEFIT SPECIAL INTERESTS
}

\author{
D. Daniel Sokol
}

\section{INTRODUCTION}

In his bestseller, The Andromeda Strain, Michael Crichton tells the story of a virus that the government tries to use as an ultimate weapon. The virus gets out of control and needs to be restrained. In antitrust, there is a similar government-created problem - that of antitrust immunities - where government immunizes a monopolist from antitrust regulation. The action that government immunizes spreads its bad effects both domestically and globally. Paradoxically, the cure (antitrust) is not allowed to treat the virus (monopoly power), because the government has already rendered the virus immune from this sort of treatment.

When government regulates, it may either intentionally or unintentionally generate restraints that reduce competition ("public restraints"). Public restraints allow a business to cloak its action in government authority and to immunize it from antitrust regulation. ${ }^{1}$ Private businesses may misuse the government's grant of antitrust immunity to facilitate behavior that benefits businesses at consumers' expense. One way is by obtaining government grants of immunity from antitrust scrutiny. A recent series of Supreme Court decisions has made this situation worse by limiting the reach of antitrust law in favor of sector regulation. ${ }^{2}$ This is true even though the Su-

* Assistant Professor, University of Florida Levin College of Law. I wish to thank Peter Carstensen, Dan Crane, Mark Fenster, Susan Franck, David Gerber, Tom Ginsburg, Jeff Harrison, Christine Klein, Phil Marsden, Bill Page, Juan Perea, Barak Richman, Ilya Somin, Maurice Stucke, Ed Swaine, Phil Weiser, and Todd Zywicki for their comments. 1 also would like to thank the staff and editors of the George Mason Law Review for their excellent work. All errors remain mine.

1 Timothy J. Muris, Principles for a Successful Competition Agency, 72 U. CHI. L. REV. 165, 170 (2005) ("Protecting competition by focusing solely on private restraints is like trying to stop the water flow at a fork in a stream by blocking only one channel. A system that sends private price fixers to jail, but makes government regulation to fix prices legal, has not completely addressed the competitive problem. It has simply dictated the form that the problem will take.").

2 Credit Suisse Sec. (USA) LLC v. Billing, 551 U.S. 264, 279-84 (2007) (noting antitrust must defer to a sector regulator enforcing a broad regulatory scheme in the SEC context); Verizon Commc'ns Inc. v. Law Offices of Curtis V. Trinko, LLP, 540 U.S. 398, 412 (2004) ("One factor of particular importance is the existence of a regulatory structure designed to deter and remedy anticompetitive harm. Where such a structure exists, the additional benefit to competition provided by antitrust enforcement will tend to be small ...."); U.S. Postal Serv. v. Flamingo Indus., 540 U.S. 736, 748 (2004) (holding antitrust liability does not apply to the U.S. Postal Service); Pac. Bell Tel. Co. v. LinkLine Commc'ns, 
preme Court refers to antitrust law as the "Magna Carta of free enterprise." Yet the choice of sector regulation over antitrust regulation may have deleterious effects on consumers. For example, a country's banking or telecommunications incumbent may be able to influence the legislature to create a statutory monopoly. This government-created monopoly immunizes the company from antitrust law even though it can abuse its monopoly position in the market to hurt consumers. This behavior, in turn, produces significant negative externalities that may worsen the very problems that antitrust law, now forced to take a backseat to other government regulatory schemes, was intended to address. Worse, because the relationship between anticompetitive regulation and antitrust law pervades the regulatory schemes of numerous countries, the international externalities generated by public restraints and barriers to entry for foreign firms that such restraints create make this a problem with global implications. ${ }^{4}$

This Article offers a new contribution to the extensive literature on the globalization of antitrust law. The present Article focuses both on the processes of creating public restraints, as well as upon the negative impacts of these restraints. Government can exempt a company from antitrust regulation, which allows the firm unbridled discretion to monopolize and harm consumers. Much of the literature focuses on the globalization of private anticompetitive conduct by businesses across jurisdictions. ${ }^{5}$ The focus of this Article, the issue of government intervention in the economy and its competitive impacts, has taken on renewed importance as the global financial crisis has led countries to provide various benefits to favored companies, which may distort competition. Distorting competition may keep the world in recession longer, as countries may retaliate with new distortions of their own, creating a downward spiral for the global economy. Thus, local "solutions" may cause international problems, and require international resolutions.

This Article does not suggest that all public restraints are inherently bad. There are some cases in which public restraints' positive effects may outweigh their costs. Some limited immunities help markets to function or have a social purpose that has a minimal effect on competition. Where the societal benefit of reduced information costs may not be reached without government intervention, restraints that create incentives for private in-

Inc., 129 S. Ct. 1109,1123 (2009) (affirming lack of duty to deal when there is a regulatory scheme in place).

3 United States v. Topco Assocs., 405 U.S. 596, 610 (1972).

4 Matthias Busse \& Jose Luis Groizard, Foreign Direct Investment, Regulations, and Growth 21 (World Bank Policy Research, Working Paper No. 3882, 2006), available at http://papers.ssm.com/ sol3/papers.cfm?abstract id $=923229$ (concluding that excessive government regulation may restrict foreign direct investment).

5 D. Daniel Sokol, Monopolists Without Borders: The Institutional Challenge of International Antitrust in a Global Gilded Age, 4 BERKELEY BUS. L.J. 37, 41 n.1 (2007) (offering a general literature review on international antitrust). 
vestment to reduce information costs may be necessary. Public restraints may allow for these businesses to be compensated at a level at which the private return matches the societal return. For example, public restraints may create mechanisms for the exchange of information such as standard setting. ${ }^{6}$

On the other hand, current public restraints which are overly broad and force economies to become less competitive hurt consumers. Therefore, this Article addresses only those public restraints that are anticompetitive. Some public restraints appeal to a distributive agenda to reduce the societal strains that increased efficiency and globalization may cause. While globalization and increased trade are globally welfare-enhancing, ${ }^{7}$ there are winners and losers in globalization. ${ }^{8}$ Public restraints that respond to globalization, but that protect only special interests at the expense of society, are targets of the current Article.

This Article also includes a novel analysis of immunities to antitrust law as a critical subset of anticompetitive public restraints. It addresses the important domestic and international institutional dynamics of how to reduce such anticompetitive immunities. It then provides a theoretical framework to identify potential domestic and international institutional responses to public restraints and the costs and benefits of these responses. The institutional framework developed in this Article proposes both substantive policies and institutional structures that can undertake these policies. The framework builds on both new institutional economics and international organization literatures, while recognizing the difficult limitations in design and capacity that existing institutions face. No existing institution effectively addresses public restraints. Therefore, the Article concludes with recommended modifications to the World Trade Organization ("WTO")specifically, the creation of a specialized antitrust panel that would bring

6 Mark A. Lemley, Intellectual Property Rights and Standard-Setting Organizations, 90 CAL. L. REV. 1889, 1937 (2002) (stating that standard-setting may promote interoperability across products and platforms of different firms). However, firms can abuse the standard-setting process when they exclude competitors or block innovations of rivals. HERBERT HOVENKAMP, MARK D. JANIS \& MARK A.

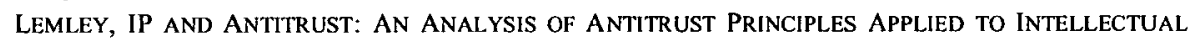
PROPERTY LAW $\S \S 35.4-35.8$ (2003). It may be that some public restraints are neutral when it comes to competitive effects. This Article addresses only those restraints that have anticompetitive effects.

7 Sebastian Edwards, Openness, Productivity and Growth: What Do We Really Know?, 108 ECON. J. 383, 396 (1998); Jeffrey A. Frankel \& David Romer, Does Trade Cause Growth?, 89 AM. ECON. REV. 379, 380-81 (1999); Jeffrey D. Sachs \& Andrew Warner, Economic Reform and the Process of Global Integration (Brookings Papers on Econ. Activity 1, 2-3, 1995) available at http://www.brookings.edu/press/Journals/1995/bpeamacro951.aspx; Romain Wacziarg \& Karen Hom Welch, Trade Liberalization and Growth: New Evidence, 22 WORLD BANK ECON. REV. 187, 187-90 (2008).

8 See, e.g., Francisco Rodriguez \& Dani Rodrik, Trade Policy and Economic Growth: A Skeptic's Guide to the Cross-National Evidence, 15 MACROECONOMICS ANN. 261, 317-18 (2000). 
together antitrust and trade analyses - as the best solution in an imperfect world to address anticompetitive public restraints.

Part I of this Article explores the causes and effects of public restraints. Part II analyzes the potential institutional choices to address public restraints. In Part III, this Article undertakes a case study of the current inadequacies of existing institutional solutions to the problem of government restraints. Part III then suggests a set of reforms to correct for the existing institutional shortcomings. The Conclusion suggests that a modified WTO is the least bad alternative to address international antitrust public restraints.

\section{THE PROBLEM OF PUbliC RESTRAINTS}

\section{A. Types of Public Restraints}

Public restraints can be distinguished from situations in which a business may have achieved a monopoly position through, as the Supreme Court states, " growth or development as a consequence of a superior product, business acumen, or historic accident." What distinguishes a monopoly position via anticompetitive public restraints from one that emerges from "business acumen" is the use of government power to monopolize through the creation of barriers to reduce competition. Public restraints may have important ramifications on economic growth and development by raising the cost of capital and placing barriers to business entry and exit. ${ }^{10}$ Such anticompetitive public restraints may impact international entry into a domestic market." Public restraints harm consumers because they ultimately pay for the cost of protection through higher taxes and/or prices to subsidize the public restraints.

Public restraints may have a more significant impact in situations in which the business aided by such restraints has substantial market power independent of the restraint. ${ }^{12}$ Market power in conjunction with public restraints allows for far-reaching negative effects on consumers in two ways. First, an industry immunized from antitrust law coverage may act anticompetitively in its own sector, where it can restrict output, refuse to

9 Verizon Commc'ns Inc. v. Law Offices of Curtis V. Trinko, LLP, 540 U.S. 398, 407 (2004) (quoting United States v. Grinnell Corp., 384 U.S. 563, 570-71 (1966)).

10 The more severe the public restraint, the greater the potential benefit of a particular interest group to use govemment to create such a restraint. Gordon Tullock, The Welfare Costs of Tariffs, Monopolies, and Thefi, 5 W. ECON. J. 224 (1967).

11 Raghuram G. Rajan \& Luigi Zingales, The Great Reversals: The Politics of Financial Development in the 20th Century, 69 J. FIN. ECON. 5, 20 (2003); Simeon Djankov et al., The Regulation of Entry, 117 Q.J. ECON. 1, 35 (2002).

12 Pietro Crocioni, Can State Aid Policy Become more Economic Friendly?, 29 WORLD COMPETITION 89, 92 (2006). 
deal with competitors, and raise prices without any concern for antitrust law ramifications. Such support allows businesses with a monopoly to exercise their monopoly power to pursue aggressive predation strategies. ${ }^{13}$ Second, a public restraint that allows for a sector to be immunized from antitrust scrutiny can create distortions in other sectors of the economy. ${ }^{14}$ An immunity creates the possibility of cross-subsidization from the immunized product or service to one in which there is competition. For example, if a postal service provider has a monopoly because of legislation (such as the U.S. Postal Service), there is the potential for the provider to anticompetitively crosssubsidize into next day delivery services, where there is competition from other firms. ${ }^{15}$

Government distorts the competitive process through public restraints, which create de facto subsidies to firms. Subsidies reduce budgetary constraints on firms. And this reduces the incentive for firms to maximize their efficiency, since government serves to protect them from competition. ${ }^{16}$ Antitrust enforcers or private litigants may have difficulty in imputing these subsidies into cost tests that would determine the true cost associated with exclusionary conduct such as predation. ${ }^{17}$

Immunities from antitrust law privilege other forms of regulation over antitrust regulation and cause competitive distortions, which may have international effects. Anticompetitive public restraints can have international effects in one of two ways. First, anticompetitive practices may be exported to other countries through spillover effects from inadequate domestic remedies. ${ }^{18}$ In these situations, the full cost of anticompetitive behavior by com-

$13 \mathrm{Id}$

14 R. Shyam Khemani, U.N. Conf. on Trade \& Dev. ("UNCTAD"), Application of Competition Law: Exemption and Exclusions 5, U.N. Doc. UNCTAD/DITC/CLP/Misc.25 (2002), available at http://www.unctad.org/EN/docs/ditcclpmisc25_en.pdf.

15 R. Richard Geddes, Pricing by State-Owned Enterprises: The Case of Postal Services, 29 MANAGERIAL \& DECISION ECON. 575, 579-86 (2008) (providing empirical evidence of anticompetitive cross-subsidization by the U.S. Postal Service); D. Daniel Sokol, Express Delivery and the Postal Sector in the Context of Public Sector Anti-Competitive Practices, 23 Nw. J. INT'L L. \& BuS. 353, 356-66 (2003) (offering cross country case studies of potential anticompetitive cross-subsidization).

16 Explicit aid may include direct financial injections through loans or subsidies to firms. Indirect support may include preferential tax treatment or other forms of compensation. Marc Hansen, Anne van Ysendyck \& Susanne Zuhlke, The Coming of Age of EC State Aid Law: A Review of the Principal Developments in 2002 and 2003, 4 EUR. COMPETITION L. REV. 202, 202 (2004).

17 D. Daniel Sokol, Comparative Corporate Governance and Competition Policy, 2009 BYU L. REV. (forthcoming 2009) [hereinafter Sokol, Comparative Corporate Governance].

18 The international market access dynamic is similar to the basic problem of federalism and restraints of trade across states. RICHARD A. POSNER, ANTITRUST LAW 281 (2d ed. 2001) ("A situation in which the benefits of govemment action are concentrated in one state and the costs in other states is a recipe for irresponsible state action. This is a genuine downside of federalism. The federal government ... is . . . less subject to take-over by a faction."); Maxwell L. Stearns, A Beautiful Mind: A Game Theoretical Analysis of the Dormant Commerce Clause Doctrine, 45 WM. \& MARY L. REV. 1, $8-9$ (2003) 
panies is not felt in their home jurisdictions. For example, a government may immunize an export cartel that fixes prices abroad, but not at home, from antitrust scrutiny. ${ }^{19}$ Such practices only negatively affect non-domestic consumers. The lack of sufficient international coordination on public restraints that create spillover effects in other jurisdictions limits what any one country can do to counteract such effects. Indeed, this is analogous to the creation of a national antitrust law under the Sherman Act because of the inability of state antitrust statutes to reach anticompetitive conduct that spilled over across states.

Second, public restraints limit opportunities for foreign businesses to compete because public restraints create barriers to entry. These government-created entry barriers limit the market's effectiveness in reducing inefficient businesses' market power. Competition stimulates increased efficiency and productivity. ${ }^{20}$ By limiting the threat of entry, public restraints reduce market dynamism. ${ }^{21}$ As most markets around the world are highly concentrated, foreign entry is often the primary source of potential competition..$^{22}$ As a result of such entry barriers, incumbent firms have fewer incentives to undertake risks that may produce innovation and economic growth.

One example of the importance of lower entry barriers can be found in the U.S. Department of Justice's ("DOJ") analysis on the competitive effects of the Whirlpool/Maytag merger. I do not address the merits of the DOJ approach, which has come under criticism. ${ }^{23}$ Rather, I use this merger to illustrate that the DOJ premised its 2006 unconditional approval of the Whirlpool acquisition of Maytag in part on the ability of foreign brands to

(arguing that the role of the dormant Commerce Clause within U.S. jurisprudence has been to limit the power of individual states in the absence of direct federal legislation).

19 D. Daniel Sokol, What Do We Really Know About Export Cartels and What is the Appropriate Solution?, 4 J. COMPETITION L. \& ECON. 967, 967-68, 974 (2008) (providing a review of the empirical literature on export cartels).

20 Jonathan B. Baker, Beyond Schumpeter vs. Arrow: How Antitrust Fosters Innovation, 74 ANTITRUST L.J. 575, 577, 587 (2007); P.J.G. Van Cayseele, Market Structure and Innovation: A Survey of the Last Twenty Years, 146 DE ECONOMIST 391, 393 (1998); Stephen J. Nickell, Competition and Corporate Performance, 104 J. POL. ECON. 724, 741 (1996); John Vickers, Concepts of Competition, 47 OXFORD ECON. PAPERS 1, $1-4$ (1995).

21 This situation may impact both static and dynamic efficiencies. Org. for Econ. Cooperation \& Dev. [OECD], Regulating Market Activities in Public Sector, 7 OECD J. COMPETTTION L. \& POL'Y 21, 33 (2005).

22 Michal S. GAL, COMPETITION POLICY FOR SMALl MARKeT ECONOMIES 8-9 (2003) (analyzing the unique problems of highly concentrated markets in small economies); Todd Mitton, Institutions and Concentration, 86 J. DEV. ECON. 367, 368 (2008) (finding higher firm level concentration in countries with higher entry costs for new entrants and in countries with weaker antitrust policy).

23 Jonathan B. Baker \& Carl Shapiro, Detecting and Reversing the Decline in Horizontal Merger Enforcement, 22 ANTITRUST 29, 30 (2008). 
enter the U.S. market should the merged entity attempt to raise prices. ${ }^{24}$ DOJ's belief was that foreign competition could discipline any price increases even though the combined company would control two-thirds of all washers and dryers produced for sale in the United States. ${ }^{25} \mathrm{Had}$ there been high barriers to foreign entry, international competition would not have been a factor in the market, and the proposed merger may have reduced competition.

Because of the cost of information, different jurisdictions may not be aware of the global nature of an anticompetitive harm caused by public restraints. Each jurisdiction will not feel the entire effect of the world-wide harm, only the harm that occurs in its own country. There may not be enough of a basis to bring a successful antitrust claim based on anticompetitive conduct because, in a limited sense, domestic antitrust law (as opposed to a broader competition policy) lacks the appropriate tools. An antitrust agency's enforcement authority stops at its nation's border, but the problems are transnational. The lack of effective domestic antitrust tools to remedy such conduct may lead to a gap in enforcement. When spillover effects or entry barriers affect international antitrust law, it may be difficult for domestic institutions to provide an adequate remedy. Moreover, it is not just an information problem that leads to under-enforcement. The jurisdiction does not capture the full benefits of enforcement - this is why there is an externality in the first place. Countries may have no incentive, either because of political capture by local monopolists or because of a country's industrial policy.

\section{B. The Difficulty of Quantifying the Impact of Public Restraints}

Most of international trade liberalization involves dismantling international public restraints. Much of this total trade gain, which is specific to the reduction of antitrust-related public restraints, is not easily quantified. Generally, regulatory barriers are more costly than tariff and other "at-theborder" barriers. ${ }^{26}$ Unlike tariffs, "behind-the-border" regulatory barriers raise the cost to foreign suppliers through expenditures that cannot be transferred to another party. Moreover, as noted above, the costs of regulatory barriers are difficult to quantify. ${ }^{27}$ However, empirical work positively as-

24 Press Release, U.S. Dep't of Justice, Antitrust Div., Statement on the Closing of Its Investigation of Whirlpool's Acquisition of Maytag (Mar. 29, 2006), available at http:/www.usdoj.gov/atr/ public/press_releases/2006/215326.htm.

25 Elizabeth Armington, Eric Emch \& Ken Heyer, The Year in Review: Economics at the Antitrust Division, 2005-2006, 29 REV. INDUST. ORG. 305, 312 (2006).

26 Alan O. Sykes, Regulatory Protectionism and the Law of International Trade, 66 U. CHI. L. REV. 1, 7-11 (1999).

27 A country can use a tariff to raise the entry cost for foreign goods. The information needed to measure the effect of this tariff for a given country is relatively easy to obtain. To do so, one collects 
sociates robust competition at the country level with growth. Antitrust regulation seems to have a statistically significant relationship to such growth. ${ }^{28}$ Given that the removal of government restraints generally has improved aggregate global welfare, it stands to reason that the removal of antitrustrelated restraints may yield significant economic benefits to consumers around the world.

Some empirical studies provide a glimpse of the extent of the antitrustrelated public restraints problem through specific sector studies. ${ }^{29}$ In one such study, the Organisation for Economic Co-operation and Development ("OECD") measured the prevalence of its member countries' public restraints. These restraints included: state control (scope of public enterprise sector, size of public enterprise sector, direct control over business enterprise, use of command and control regulation, price controls); barriers to competition (legal barriers, antitrust exemptions); and barriers to trade and investment (ownership barriers, discriminatory procedures, regulatory barriers, tariffs). ${ }^{30}$ Overall, the study found that there is less of an impact of such public restraints in OECD countries currently than in previous years. However, significant regulations that restrict competition remain in effect in nearly all OECD countries. ${ }^{31}$ Another study found that discriminatory government treatment reduced growth rates by as much as 10 percent over a three-year period. ${ }^{32}$ And a study by Simeon Djankov et al. found that government barriers make entry more difficult. ${ }^{33}$ Building upon this work, Raymond Fisman and Virginia Sarria-Allende found that countries that

information on the amount of a product that enters the market and the tariff rate placed on such products. Regulatory barriers work differently. The difficulty in estimating the cost of antitrust public restraints makes it more difficult for consumers and politicians to grasp the costs of government-created economic distortions.

28 Mark A. Dutz \& Aydin Hayri, Does More Intense Competition Lead to Higher Growth? 1 (World Bank Policy Research, Working Paper No. 2320, 1999), available at http://papers.ssm.com/sol3/ papers.cfm?abstract_id $=630693$.

29 See, e.g., DAVID M. Newbery, Privatization, Restructuring, and Regulation of NETWORK UTILITIES (1999); RoBERT BALDWIN \& MARTIN CAVE, UNDERSTANDING REGULATION: Theory, Strategy, and Practice (1999); Arturo Galindo \& Alejandro Micco, Do State Owned Banks Promote Growth? Cross-Country Evidence for Manufacturing Industries, 84 ECON. LETTERS 371 (2004); Paola Sapienza, The Effects of Government Ownership on Bank Lending, 72 J. FIN. ECON. 357 (2004).

30 Paul Conway, Veronique Janod \& Guiseppe Nicoletti, Product Market Regulation in OECD Countries: 1998 to 20038 (OECD, Working Paper No. 419, 2005), available at http://ideas.repec.org/p/ oec/ecoaaa/419-en.html.

31 Id. at 32 . There is a lack of similar empirical measures on public restraints in a developingworld context.

32 Joel S. Hellman, Geraint Jones \& Daniel Kaufmann, Far From Home: Do Foreign Investors Import Higher Standards of Governance in Transition Economies? 14 (World Bank Institute Policy Research, Working Paper No. 2444, 2000) available at http://papers.ssm.com/sol3/papers.cfm?abstract id $=386900$.

33 Djankov et al., supra note 11 , at 3-4. 
heavily regulate entry through public restraints in sectors with low natural barriers to entry experience a high concentration of large firms. ${ }^{34}$ Higher concentration increases the possibility of monopolization.

\section{Causes of Public Restraints}

Regulations themselves cause public restraints by allowing, or even requiring, anticompetitive behavior. As other forms of regulation may preempt antitrust law implicitly or explicitly, this anticompetitive behavior is immune from prosecution under antitrust laws. Moreover, overly broad (or just badly decided) judicial decisions may increase the scope of public restraints. Thus, the sector regulator, the legislature, and the judiciary can each cause and perpetuate public restraints. ${ }^{35}$

Public choice theory, and its application of economic rational choice theory to politics, clarifies how anticompetitive public restraints come into being. ${ }^{36}$ Public choice explains that regulation is often a product of rentseeking (manipulating the regulatory environment for personal gain) by interest groups. ${ }^{37}$ Consequently, laws and regulations will tend to benefit small, well-organized interest groups rather than society overall. Interest groups (mis)use government to create immunities from antitrust law. This rent-seeking behavior by interest groups redistributes resources away from their efficient use to use by other actors. ${ }^{38}$ Rent-seeking thus limits the opportunities for growth by a country. ${ }^{39}$

34 Raymond Fisman \& Virginia Sarria-Allende, Regulation of Entry and the Distortion of Industrial Organization 4 (Nat'l Bureau of Econ. Research, Working Paper No. 10929, 2004), available at http://www.nber.org/papers/w10929.

35 Deborah Platt Majoras, State Intervention: A State of Displaced Competition, 13 GEO. MASON L. REV. 1175, 1179-82 (2007) (providing examples of such restraints).

36 William N. Eskridge, Jr. \& Philip P. Frickey, Legislation Scholarship and Pedagogy in the Post-Legal Process Era, 48 U. PITT. L. REV. 691, 703 (1987) ("The legislature is a political battlefield; most of its activity is no more purposive than the expedient accommodation of special interest pressures."). See also Daniel A. Farber \& Philip P. Frickey, The Jurisprudence of Public Choice, 65 TEX. L. REV. 873, 874-75 (1987); DENNIS C. MUELlER, PUBLIC CholCE III (3d ed. 2003) (reviewing recent literature in public choice theory). Public restraints are not caused merely by public choice problems. There are also situations where a majority of the electorate may choose bad economic policies, such as with price controls. However, as an empirically untested observation, it seems that public choice explanations account for more of antitrust public restraints, especially regarding immunities, and so this Article focuses on political malfunctions due to public choice concerns in antitrust law and policy.

37 See, e.g., James M. BUCHANAN \& Gordon TUllock, THE Calculus of CONSENT: Logical Foundations of CONSTITUTIONAL DEMOCRACY 9 (1962); George J. Stigler, The Theory of Economic Regulation, 2 BELL J. ECON. \& MGMT. SCI. 3, 3 (1971).

38 Mancur olson, The logic of Collective action: Public goods and the Theory of GROUPS $141-48$ (1965).

39 Kevin M. Murphy, Andrei Shleifer \& Robert W. Vishny, Why is Rent-Seeking so Costly to Growth?, 83 AM. ECON. REV. 409, 409 (1993). 


\section{Legislative Immunities}

The legislative failure that strengthens the position of interest groups over that of the general population explains why many antitrust immunities come into being. ${ }^{40}$ In a world of interest groups, antitrust agencies may be less politically powerful than other interest groups that shape regulation. Antitrust law does not have a well organized and powerful constituency with which to push for procompetitive change. ${ }^{41}$ Unlike specific policies that benefit a particular industry or other interests (e.g., labor), the benefits of antitrust law are diffuse. Increased welfare affects each consumer, whether a business or individual, only marginally, though the aggregate societal consequences may be significant.

There are many examples of how the public choice dynamic works in legislation that negatively impacts or limits antitrust regulation. The passage of the Robinson-Patman Act, ${ }^{42}$ for example, can be explained in large part as a public choice story. ${ }^{43}$ The Act's purpose was to protect competitors. $^{44}$ The Act had its origins in the work of the United States Wholesale Grocers Association, which proposed the precursor to the Act at its 1935 annual meeting. ${ }^{45}$ The initial title of the Act reflected the particular interest group that sought protection-"Wholesale Grocer's Protection Act."46 In particular, the Act was an attempt by politically well-organized smaller retailers to reduce the ability of the A\&P grocery chain to use its scale ad-

40 Sam Peltzman, Toward a More General Theory of Regulation, 19 J.L. \& ECON. 211,212 (1976) ("A common, though not universal, conclusion has become that, as between the two main contending interests in regulatory processes, the producer interest tends to prevail over the consumer interest." (footnote omitted)).

41 This of course assumes that antitrust's purpose is procompetitive in nature and that competition means efficiency enhancing. The current state of antitrust law in the U.S., for example, is based on a Chicago School approach. William H. Page, The Chicago School and the Evolution of Antitrust: Characterization, Antitrust Injury, and Evidentiary Sufficiency, 75 VA. L. REV. 1221, 1228-43 (1989) (explaining the emergence of the Chicago School). However, U.S. antitrust law went through periods of populist driven enforcement. See RICHARD HOFSTADTER, What Happened to the Antitrust Movement?, in THe PARANOId STYle in AMERICAN POLITICS, AND OTHER ESSAYS 188, 195-96 (1967).

4215 U.S.C. $\$ 13$ (1936) (limiting price discrimination).

43 But see Jerrold G. Van Cise, Religion and Antitrust, 23 ANTITRUST BULL. 455, 480-81 (1978) (arguing that Robinson-Patman reduced arbitrariness in prices by forcing producers and distributors to rationalize their pricing policies).

44 F.M. SCHERER \& DAVID ROSS, INDUSTRIAL MARKET STRUCTURE AND ECONOMIC PERFORMANCE 515-16 (3d ed. 1990).

45 Earl W. Kintner, a Robinson-Patman Primer: a guide to the Law against Price DISCRIMINATION 10 (2d ed. 1979).

46 Margaret M. Zwisler, Volvo Trucks v. Reeder-Simco: Judicial Activism at the Supreme Court?, 20 ANTITRUST 40, 41 (2006). 
vantage to extract better terms from suppliers than its smaller competitors through price discrimination or buyer power. ${ }^{47}$

Explicit and implicit immunities to antitrust regulation may be included in the initial antitrust law and regulations of a country's antitrust system for public choice reasons. Restrictions on the ability of an antitrust agency to act because of immunities in the antitrust law, or other laws that provide sole jurisdiction to sector regulators, set up the parameters for antitrust regulation in a given market. This limits the ability of antitrust agencies to police against market-distorting behavior that the government creates or facilitates. One such case of a direct exemption is Singapore's Competition Act of 2004. The Act's prohibitions against anticompetitive conduct do not apply to the government, any statutory body, or person acting on behalf of the government. ${ }^{48}$ Moreover, the Act creates a number of sector exclusions, such as for postal, rail, and cargo services. ${ }^{49}$ In other areas, competition oversight of sector-specific businesses has been exempted (e.g., telecoms, media, and energy). Given the political power of some of the state-owned enterprises in Singapore (via the government holding company Temasek Holding Pte., which, as a sovereign wealth fund, also bought a stake in Merrill Lynch in late 2008) and the problems of public choice in regulation, such exemptions have the potential for significant anticompetitive effect. ${ }^{50}$ In countries that are far less open to competition, such as China, a similar pattern is emerging. Article 7 of the new Chinese AntiMonopoly $\mathrm{Law}^{51}$ creates immunities from antitrust regulation for state owned enterprises in "strategic" sectors, which include such economic drivers as aviation, banking, electricity, oil, railroads, and telecommunications. 52

The political process may, after adopting an antitrust law, add various immunities from antitrust coverage for favored industries and sectors, for reasons of public choice. The U.S. experience, in which immunities have had significant staying power, exemplifies how difficult it is to get a do-

47 Joel B. Dirlam \& Alfred E. Kahn, Antitrust Law and the Big Buyer: Another Look at the A\&P Case, 60 J. POL. ECON. 118, 118-19 (1952) (analyzing the buyer power of A\&P). The effect of Robinson-Patman in its early years (1936-1959) also primarily impacted the food sector, with 87 percent of Federal Trade Commission ("FTC") orders regarding unlawful brokerage dealing with food products. CORWIN D. EDWARDS, THE PRICE DISCRIMINATION LAW: A REVIEW OF EXPERIENCE 74 (1959).

48 Competition Act 2004, Bill No. 22/2004, at § 33(4) (Sing.).

49 Id. ๆๆ 5-7, Third Schedule.

50 Among Temasek's holdings are critical players in the Singaporean economy such as Singapore Airlines, Singapore Telecommunications, DBS Bank, and hotelier Raffles Holdings.

51 Anti-Monopoly Law of the People's Republic of China (promulgated by the Standing Comm. Nat'l People's Cong., Aug. 30, 2007, effective Aug. 1, 2008), available at http://china.org.cn/ government/laws/2009-02/10/content_17254169.htm.

52 Eleanor M. Fox, An Anti-Monopoly Law for China-Scaling the Walls of Government Restraints, 75 ANTITRUST L.J. 173 (2008) (providing an analysis of antitrust public restraints in China). 
mestic legislature to rein in these exemptions. ${ }^{53}$ A statutorily embedded system of immunities makes remedying such conduct difficult because favored interest groups will lobby hard to keep those immunities. ${ }^{54}$ Indeed, such preferences strengthen existing interest groups, and can even create additional interest groups, with a vested interest in the continued regulatory creep of such immunity. ${ }^{55}$

The history of the Soft Drink Interbrand Competition Act of 1980 provides an example of a rent-seeking immunity enacted after passage of an antitrust law. The Act authorized the elimination of intrabrand competition of soft drinks within a bottler's territory. ${ }^{56}$ The Act was a legislative response to FTC litigation against soft drink bottlers in which the use of exclusive territories by bottlers was found to be anticompetitive. In the FTC case, bottlers limited intrabrand competition in service territories. ${ }^{57}$ As a response to the FTC decision, which declared the bottlers' exclusive franchise arrangements illegal, special interests worked to pass national legislation to use government to shield this conduct through the Act. ${ }^{58}$

The legislature is not the only institution that suffers from public choice concerns. It is endemic to all institutions. ${ }^{59}$ However, unlike other institutions, like the judiciary, the legislature has the ability to significantly reduce its public choice problems through the creation of sunset provisions that would cause immunities from antitrust regulation to expire at a certain

53 A number of the U.S. exemptions trace back to the 1930 s and some even earlier, such as the Anti-Hog-Cholera Serum and Hog-Cholera Virus Act. See, e.g., 7 U.S.C. $\$ 852$ (1935).

54 MUELLER, supra note 36, at 353.

55 David Currie \& John Cubbin, Regulatory Creep and Regulatory Withdrawal: Why Regulatory Withdrawal is Feasible and Necessary 2 (City Univ. Working Paper, 2002), available at http://www.staff.city.ac.uk/ sm340/Consulting\&Policy/Regulatory\%20Withdrawal\%20Report\%20020317.pdf ("More generally, there is a prevalent view that regulatory creep is inevitable; that regulators will be unwilling to let go and indeed will be inclined to increase over time the range and scope of what they control.").

56 For a detailed description of the politics involved in the enactment of this legislation, see Am. Antitrust Inst., Comments of the American Antitrust Institute Working Group on Immunities and Exemptions 3 (2005), available at http:/govinfo.library.unt.edu/amc/public_studies_fr28902/immunities exemptions_pdf/050715_AAI.pdf. See also ABA, FEDERAL STATUTORY EXEMPTIONS From ANTITRUST LAW 49-50 (2007).

57 In re Coca Cola Co., 91 F.T.C. 517 (1978).

58 The period after the passage of the Act witnessed a flurry of Department of Justice investigations and convictions of price fixing by bottlers. Not surprisingly, the Act facilitated this collusion. harold Saltzman, Roy levy \& John C. Hilke, Fed. Trade Comm'n, Transformation and CONTINUITY: THE U.S. CARBONATED SOFT DRINK BOTTLING INDUSTRY AND ANTITRUST POLICY SINCE 1980139 (1999), available at http://www.ftc.gov/reports/softdrink/softdrink.pdf.

59 This includes antitrust agencies. David J. Gerber, Transatlantic Economic Governance: The Domains and Dimensions of Competition Law, in THE FUTURE OF TRANSATLANTIC ECONOMIC Relations: ContinUiTy Amid DisCORD, 81, 93 (Mark Pollack \& Greg Shaffer eds., 2005); Donald I. Baker, Antitrust and Politics at the Justice Department, 9 J.L. \& POL. 291, 291 (1993) ("Antitnust and politics are inevitably intertwined, not only in the United States but in any country having an effective antitrust program."). However, as noted later in this Article, antitnst agencies are less prone to public choice concerns than sector regulators or the legislature. 
set date. ${ }^{60}$ With sunset provisions, political factions would need to revisit the political debate to justify the continuation of immunities via the legislative process. This would increase accountability and most probably reduce the number of immunities because the true costs of such legislation would be exposed. ${ }^{61}$

\section{Judicial Immunities}

The judiciary may create public restraints and immunize anticompetitive behavior through case law. ${ }^{62} \mathrm{~A}$ brief review of the U.S. experience illustrates how judicially-created immunities can be created and expanded in scope over time. ${ }^{63}$ For example, the state action exemption is a judiciallycreated exemption to antitrust scrutiny, arising from the 1943 case of Parker v. Brown. ${ }^{64}$ In Parker, a raisin producer attempted to enjoin enforcement of a mandatory California program that controlled the marketing and sale of agricultural products. ${ }^{65}$ The effect of Parker was to shield anticompetitive state laws and their private party beneficiaries that fall within the state action exemption. In California Retail Liquor Dealers Ass'n $v$. Midcal Aluminum, Inc. ${ }^{66}$ the Supreme Court created a two-pronged test for a private party to determine what accounts for permissible state supervision and exemption from antitrust scrutiny ${ }^{67}$ Under this two-pronged test, a party must show that its conduct in question is: (1) "clearly articulated and affirmatively expressed as state policy;" and (2) "actively supervised by the

60 Such a proposal has support across the scholarly political divide. For a leftist critique of antitrust immunities, see DARREN BUSH, GREGORY K. LEONARD \& STEPHEN F. ROSS, A FRAMEWORK FOR POLICYMAKERS to ANALYZE PROPOSED AND EXISTING ANTITRUST IMMUNITIES AND EXEMPTIONS (2005), available at $\mathrm{http}: / /$ papers.ssm.com/sol3/papers.cfm? abstract_id $=956597$.

61 George K. Yin, Temporary-Effect Legislation, Political Accountability, and Fiscal Restraint, 84 N.Y.U. L. REV. 174, 192-94 (2009).

62 The complexity of the economics of antitrust may overwhelm the judiciary. See, e.g., Michael R. Baye \& Joshua D. Wright, Is Antitrust Too Complicated for Generalist Judges? The Impact of Economic Complexity \& Judicial Training on Appeals 6 (Geo. Mason L. \& Econ. Research Paper Series, Research Paper No. 09-07, 2009), available at http://ssm.com/abstract_id=13119888.

63 These issues are, of course, tied into federalism. State action concems are not unique to the United States. EU case law shows deference to Member States and their decision-making. See Richard Wainwright \& André Bouquet, State Intervention and Action in EC Competition Law, in ANNUAL PROCEEDINGS OF THE FORDHAM CORPORATE LAW INSTITUTE: INTERNATIONAL ANTITRUST LAW \& POLICY 2003551 (Barry Hawk ed., 2004); Case C-198/01, Consorzio Industrie Fiammiferi (CIF) v. Autorità Garante della Concorrenza e del Mercato, 2003 E.C.R. 1-8055; Fernando Castillo de la Torre, State Action Defence in EC Competition Law, 28 WORLD COMPETITION 407, 430 (2005).

64317 U.S. 341, 350-51 (1943) (involving discrimination within a federal system where 90 percent of raisins were shipped out of state). In this case, local politics favored anticompetitive conduct that imposed costs on non-voting out-of-staters. Id.

65 Id.

66445 U.S. 97 (1980).

67 Id. at 105-06. 
[s]tate itself." ${ }^{68}$ In the twenty-five years since Midcal, the scope of the state action exemption has grown.

As part of a more general push to combat public restraints, the FTC recently undertook a comprehensive study of the state action exemption through a State Action Task Force. ${ }^{69}$ The State Action Task Force Report concluded that over time courts have weakened limitations on the doctrine. Both the "clear articulation" and "active supervision" requirements have been the subject of varied and controversial interpretation, sometimes resulting in unwarranted expansions of the exemption. ${ }^{70}$ The criteria for "active supervision" remain unclear. Because of its opaqueness, the active supervision requirement has not adequately limited exemptions under the state action doctrine. ${ }^{11}$ There is also some lack of clarity as to the "clear articulation" prong. One set of cases, particularly those that have reached the Supreme Court, has interpreted the "clear articulation" prong to allow states broadly to displace competition as a result of a legislative grant of general corporate powers. ${ }^{72}$ The Supreme Court expanded what constitutes clear articulation. In Town of Hallie v. City of Eau Claire, ${ }^{73}$ the Supreme Court held that the "clear articulation" test was satisfied when the anticom-

$68 I d$. at 105 (internal quotation marks purposely omitted).

69 TODD J. ZYWICKI, FED. TRADE COMM'N, REPORT OF THE STATE ACTION TASK FORCE (2003), available at http://www.ftc.gov/os/2003/09/stateactionreport.pdf. The Task Force never questioned whether there should be any state action exemption, merely how to better limit the exemption. Id. at 3 . The State Action Task Force recommendations suggest a concern that public restraints on trade can serve anticompetitive ends and need to be circumscribed. Because the state action doctrine rests upon federalism, actions of the state and its actors are shielded. There is no reason why state action needs to rest on federalism grounds. The federal government could choose to directly regulate these issues and take away discretion from the states. The recommendations of the State Action Task Force beg a larger question. Instead of examining the limitations of an exemption that has anticompetitive results, why not abolish the exemption? The answer would suggest that public choice concerns limit the FTC's ability to eliminate this or other exemptions. Public choice significantly circumscribes the ability of an established competition system, such as that of the United States, from acting against immunities. One can understand why in countries with a more recent transition to liberalization and new antitrust agencies the possibility of overcoming immunities is much greater.

70 See John T. Delacourt \& Todd J. Zywicki, The FTC and State Action: Evolving Views on the Proper Role of Government, 72 ANTITRUST L.J. 1075, 1087 (2005) (arguing that public choice thinking has not created a more systematic framework to address state action cases).

71 The State Action Task Force recommends that active supervision be narrowly defined. Active supervision would entail three requirements: (1) the development of an adequate factual record, including notice and an opportunity for critics of the policy to be heard; (2) a written decision on the merits; and (3) a specific assessment-both qualitative and quantitative - of how the private action comports with the substantive standards established by the state. ZYWICKI, supra note 69, at 37

72 Id. at 26-34. Clear articulation rests on whether "the State as sovereign clearly intends to displace competition in a particular field with a regulatory structure." S. Motor Carriers Rate Conference, Inc. v. United States, 471 U.S. 48, 64 (1985); Darren Bush, Mission Creep: Antitrust Exemptions and Immunities as Applied to Deregulated Industries, 2006 UTAH L. REV. 761, 767 (noting that some recent cases at the district court level apply a less broad foreseeability standard).

73471 U.S. 34 (1985). 
petitive conduct was the "foreseeable result" of a state statute. This foreseeable result standard has led courts to allow significant anticompetitive behavior to be shielded through "clear articulation" by either a general state authority or through a broad regulatory regime. ${ }^{74}$

\section{Indirect Immunities-Regulatory Creep of Sector Regulators}

Sector regulation may create an explicit ${ }^{75}$ or implicit ${ }^{76}$ immunity from antitrust regulation. This mechanism of public restraints is different from legislative public restraints because in sector regulation, regulators create restraints through administrative law. The extent of sector regulation and the decision-making of sector regulators define the parameters for business regulation. Thus, a sector regulator that sets high barriers to entry affects the competitiveness of a market and the ability of antitrust regulation to function as a policy tool to correct market failures. ${ }^{77}$

Countries may choose sector regulator oversight over antitrust law for reasons of public choice. Sector regulation may be more open to manipulation and capture by interest groups, resulting in the creation of more public restraints. Because in some cases sector regulators may have preceded antitrust agencies, there may be a sense among some sector regulators of a turf war over control of regulation in that sector. Sector regulators may see an antitrust agency as a potential threat for funding and prestige. This threat of competing regulators may cause a sector administrator to seek greater control (and more power and funding) over its regulated industry. ${ }^{78}$ Such sector regulators might take steps to limit the role that an antitrust agency might take in that particular sector.

Some sector regulation historically has served a market replacement rather than market facilitation function. ${ }^{79}$ Sector regulators therefore still

74 Some district court level cases take an alternative view on foreseeability. See, e.g., Capital City Cab Serv., Inc. v. Susquehanna Area Reg'l Airport Auth., 470 F. Supp. 2d 462, 468 (M.D. Pa. 2006).

75 See the appendices in INTERNATIONAL COMPETITION NETWORK [ICN], INTERRELATIONS BETWEEN ANTITRUST AND REgUlatory AUTHORITIES: REPORT TO THE THIRD ICN ANNUAL CONFERENCE (2004) [hereinafter ICN, INTERRELATIONS BETWEEN ANTITRUST AND REGULATORY AUTHORITIES], available at http:/www.internationalcompetitionnetwork.org/media/library/conference _3rd_seoul_2004/aers_sg3_seoul.pdf.

$\overline{76}$ See, e.g., Keogh v. Chicago \& Nw. Ry., 260 U.S. 156, 165 (1922); Gordon v. N.Y. Stock Exch., 422 U.S. 659, 691 (1975).

77 ICN, INTERRELATIONS BETWEEN ANTITRUST AND REGULATORY AUTHORITIES, supra note 75, at 5 .

78 William A. Niskanen, JR., Bureaucracy and Representative Government 195-223 (1971); Jonathan Bendor, Serge Taylor \& Roland van Gaalen, Bureaucratic Expertise versus Legislative Authority: A Model of Deception and Monitoring in Budgeting, 79 AM. POL. SCI. REV. 1041, 1042 (1985).

79 See, e.g., Ekaterina Markova, Liberalization and REgulation of the TELECOMMUNICATIONS SECTOR IN TRANSITION COUNTRIES: THE CASE OF RUSSIA 81-82 (2009). 
may focus on industry concerns, rather than on the competitive process, as a means of improving societal welfare. Additionally, because sector regulators focus on a specific industry, as repeat players they are more prone than antitrust agencies to capture by those in a particular industry with a vested interest in sector outcomes. This repeat play of actors within a narrow band of interests may make sector regulators easier to capture than antitrust enforcers, since the latter's oversight exposes them to many industries and interest groups, while the former must deal with the focused attentions of the same interest groups over and over. Particularly in the developing world, the low pay of sector regulators increases the likelihood of capture. ${ }^{80}$ In addition to direct pressure from industry groups, sector regulators may be prone to specific pressure from legislators interested in that sector, further exacerbating the problem of capture. ${ }^{81}$

Sector regulation also may be prone to manipulation by companies that attempt to game the regulatory system. Such gaming may occur when, because of concurrent sector and antitrust regulation, anticompetitive behavior results from regulatory schemes that allow for subsidies from a regulated market (sector regulator) to an unregulated market (antitrust). Anticompetitive cross-subsidization allows monopoly firms in the regulated sector to raise the cost of rivals from the unregulated sector or to price below marginal cost for a sustained period to drive out competitors. ${ }^{82}$ In this regard, regulated firms may benefit from cross subsidies because inputs of the regulated network may be used to compete in the unregulated sector, whereas the cost is allocated to the regulated sector.

The example of telecommunications services in Taiwan suggests how a regulated firm can game the regulatory system for anticompetitive ends through public restraints. In 1999, the Taiwanese state-owned telecommunication incumbent, Chunghwa Telecom, introduced a service that allowed users to have call answer, call transfer, voicemail, collect call capacity, and information management. ${ }^{83}$ It branded this service "099 service." At the time, Chunghwa held a government-designated monopoly (i.e., an antitrust immunity) in fixed telephony, but competed against five companies in mobile telephony. Pricing of 099 was almost half the cost of competitor serv-

80 James R. BARth, Gerard CAPrio, JR. \& Ross LeVINe, Rethinking Bank Regulation: TILL ANGELS GOVERN 34 (2006).

81 See Todd J. Zywicki, Dir., Office of Policy Planning, Fed. Trade Comm'n, Competition Policy and Regulatory Reform: Means and Ends, Address at the Competition Policy Research Center, Fair Trade Commission of Japan Inaugural Symposium 4 (Nov. 20, 2003), available at http://www.ftc.gov/speeches/other/031120zywickijapanspeech.pdf; Mariana Mota Prado, The Challenges and Risks of Creating Independent Regulatory Agencies: A Cautionary Tale from Brazil, 41 VAND. J. TRANSNAT'L L. 435 passim (2008).

82 See, e.g., World Bank, Telecommunications Regulation Handbook, Module 5, 17-23 (2000), available at http://www.infodev.org/en/Publication.22.html.

83 OECD, ABUSE OF DOMINANCE IN REGULATED SECTORS 2 (2005), available at http://www.oecd.org/dataoecd/1 1/23/34339796.pdf. 
ices. ${ }^{84}$ This was not a function of superior technology or business acumen. Rather, it was a function of Chunghwa's ability to cross subsidize from its fixed telephone monopoly (where it could charge a premium) to the mobile sector where it competed with other firms. This policy caused Chunghwa to increase fixed line local rates for local 099 calls by 900 percent, while it decreased local to mobile rates for 099 calls by 40 percent. $^{85}$

\section{InStitutional ChOICES TO ADDRESS PUBLIC RESTRAinTS}

\section{A. Institutional Choice}

This Article undertakes a comparative institutional analysis of the costs and benefits of various institutional alternatives to combat public restraints. ${ }^{86}$ To determine which institution is the best suited vis-à-vis other institutions to solve a problem, such as public restraints, one must compare institutional choices. ${ }^{87}$ Public restraints affect numerous participants across

84 Id.

$85 I d$. Both telecom and antitrust agencies ultimately played a role to remedy the anticompetitive behavior. Id. at 4-5.

86 Scholars ascribe different meanings to the terms "institution" and "comparative institutional analysis." See, e.g., OLIVER E. Williamson, THE ECONOMIC INSTITUTIONS OF CAPITALISM: FIRMS, MARKETS, RELATIONAL CONTRACTING (1985); DOUGLASS C. NORTH, INSTITUTIONS, INSTITUTIONAL Change and ECONOMic Performance (1990); Masahiko AOKI, Toward a Comparative INSTITUTIONAL ANALYSIS (2001); THRÁINN EGgERTSSON, IMPERFECT INSTITUTIONS: POSSIBILITIES AND LIMITS OF REFORM (2005); THE NEW INSTITUTIONALISM IN ORGANIZATIONAL ANALYSIS (Walter W. Powell \& Paul J. DiMaggio eds., 1991); THE RISE of NEOliberalism and InStituTIONAL ANALYSIS (John L. Campbell \& Ove K. Pederson eds., 2001); EIRIK G. FURUBOTN \& RUDOLF RICHTER, INSTITUTIONS AND ECONOMIC THEORY: THE CONTRIBUTION OF THE NEW INSTITUTIONAL ECONOMICS (1997); NEIL K. KOMESAR, IMPERFECT ALTERNATIVES: CHOOSING INSTITUTIONS IN LAW, ECONomics, ANd Public POLICY (1994); NeW Institutional ECONOMICS: A Guidebook (Éric Brousseau \& Jean-Michel Glachant eds., 2008). The present Article defines institutions according to North, as the governance structures of formal rules, informal norms, their organizational structure, and the ways in which these structures enforce governance. Douglass C. North, Economic Performance Through Time, 84 AM. ECON. REV. 359, 360 (1994). By comparative institutional analysis, this Article uses Williamson's conceptualization. WILLIAMSON, supra, at 2 (offering "an examination of the comparative costs of planning, adapting, and monitoring task completion under alternative governance structures").

87 In a previous article, I developed a theoretical framework of comparative institutional analysis of antitrust and applied it to the issues of antitrust that had the most direct day-to-day impact in international antitnust-mergers, cartels, and market access. I concluded that the strength of soft law organizations, and in particular the International Competition Network ("ICN"), was the best institutional choice to push for increased effectiveness to address international antitrust issues. Sokol, supra note 5, at 118 . A comparative institutional analysis of antirust public restraints creates a particular problem with the previous comparative analysis. Because the current Article addresses a specific subset of issues within international antitrust, public restraints, there is the possibility that a comparative institutional analysis that focuses merely on this subset of issues may yield a different set of institutional alternatives than a 
many jurisdictions because of their global impact. This dynamic renders any one institutional solution imperfect. Instead, any potential institutional choice is a choice among the least bad alternatives. The global problem of public restraints requires a comparative institutional analysis at both horizontal levels (interplay between domestic institutions and interplay between international institutions) and vertical levels (interplay between domestic and international institutions). This Section explains the dynamics and interactions of these institutional choices.

Domestic level institutional choice allows for more localized approaches that adjust to the contours of regulatory and socio-economic situations at the country level. ${ }^{88}$ "This may reduce information asymmetries between the regulator" and firms that exist with international institutional choices. ${ }^{89}$ On the one hand, it may be easier to overcome transaction costs at the international level than at the domestic level for global problems. ${ }^{90}$ International institutions may allow for coordination to overcome international antitrust public restraints. On the other hand, international institutions may create a global set of standards that may cause more harm than good, if standards are set too low or if capture occurs globally. Among international institutions, both hard law and soft law international institutional alternatives require domestic compliance. But, as discussed below, compliance functions in different ways for hard and soft law.

comparative institutional analysis of international antitrust issues generally. Yet, the significant impact of public restraints and the current regulatory gap to address its effects justifies a comparative institutional analysis even at this more limited level for public restraints.

88 Comparative institutional analysis at the domestic level, when done across countries in the aggregate, makes some generalizations about the strengths and weaknesses of courts, agencies and the legislative process. These generalizations lead to some country-level imprecision. However, to address a global issue such as public restraints, there is a need to make more general descriptive and/or explanatory inferences based on empirical information about institutions around the world. For designing such a social inquiry, see GaRY KING, ROBERT O. KEOHANE \& SIDNEY VERBa, DESIGNING SOCIAL INQUIRY: SCIENTIFIC INFERENCE IN QUALITATIVE RESEARCH 3-32 (1994).

89 Warrick Smith, Regulating Utilities: Thinking About Location Questions 4 (World Bank Summer Workshop on Mkt. Inst., 2000), available at http://ru.worldbank.org/Documents/PapersLinks/ regulating_utilities_thinking_about_location_questions.doc.

90 Andrew Moravesik, A New Statecraft? Supranational Entrepreneurs and International Cooperation, 53 INT'L ORG. 267, 301 (1999). 


\section{Diagram A. INSTITUTIONAL ALTERNATIVES FOR ANTITRUST GOVERNANCE OF PUBLIC RESTRAINTS}

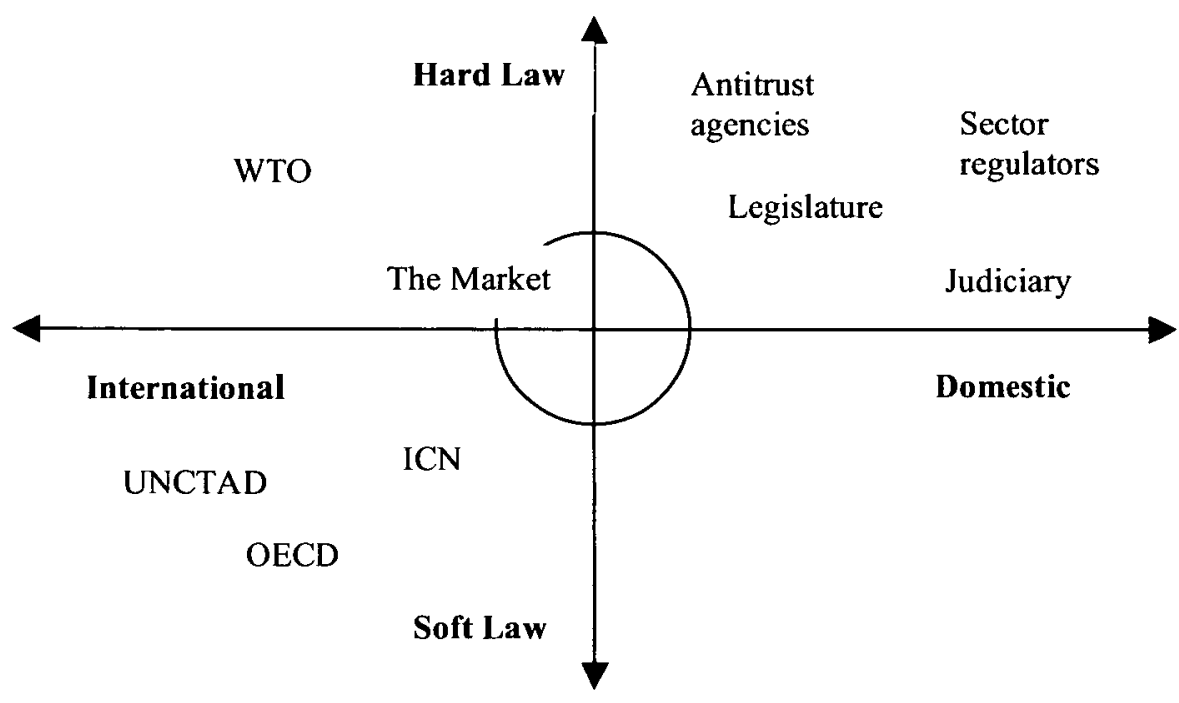

Diagram A provides a graphical overview of the various institutional choices for overcoming the negative effects of public restraint antitrust immunities. Choosing any of these institutions requires an analysis based on the costs and benefits of these institutions relative to each other. On the $x$ axis is a choice between domestic and international institutions. Domestic level institutional choice, regardless of the institution, is a decentralized approach to resolving the international effects of public restraints. International institutional alternatives must be considered to solve public restraints because public restraints have an international dimension. Moreover, the interaction between domestic and international institutions is part of a twolevel game. ${ }^{91}$ As countries make the choice for an international solution, this may lead to increased international rule-making and coordination. However, such activity requires acceptance and implementation at the domestic level. Thus, there is an institutional question of how to coordinate across domestic and international institutional choices.

On the $y$-axis is the choice between hard and soft law. ${ }^{92}$ Hard law relies upon enforceable rules administered by formal adjudication. In contrast, soft law requires standards that are not directly enforceable, except by the informal responses (the sticks of shame sanctions and the carrots of

91 Robert D. Putnam, Diplomacy and Domestic Politics: The Logic of Two-Level Games, 42 INT'L ORG. 427, 434 (1988).

92 The choices that international organizations make also involve imperfect institutional alternatives. See Michael N. Bamett \& Martha Finnemore, The Politics, Power, and Pathologies of International Organizations, 53 INT'L ORG. 699, 716-17 (1999). 
praise and commendation) of those countries and agencies that subscribe to these international norms. Soft law norms are based on lower levels of commitment, obligation, and/or precision than those found in hard law. ${ }^{93}$ Proponents of soft law focus on how it develops accepted informal norms of behavior, which may have more long-lasting effects than more strict norms of behavior imposed through formal regulation.

There are four domestic hard law institutional choices for addressing competition issues: courts, antitrust agencies, legislatures, and sector regulators. In the area of international antitrust law, the global hard law institution is the WTO. Soft law international antitrust organizations include the OECD, United Nations Conference on Trade and Development ("UNCTAD"), and the International Competition Network ("ICN"). Soft law in an antitrust context is an institutional choice of international agencyto-agency cooperation among domestic antitrust agencies. There are no significant domestic soft law antitrust institutions that shape behavior. Another institution does not fit into the two-by-two chart-the market. In lieu of regulation, it is always possible to rely upon the market either internationally or domestically. The question of how much to let the market shape the organization of society is at the core of regulatory decision-making.

\section{B. Domestic Institutional Choices}

The complex interaction among domestic institutions creates and constrains public restraints in antitrust law. Antitrust law may prove ineffective to deal with those areas in which the legislature, judiciary, or sector regulators have immunized antitrust-related conduct. Antitrust law also suffers from internal institutional constraints, in which antitrust agencies may choose inaction at times because of political backlash that a public restraints enforcement agenda may create.

\section{Legislature}

Even though the legislature is the primary creator of public restraints, it also plays the primary role in liberalizing an economy through regulatory reform and the elimination of anticompetitive regulations. ${ }^{94}$ The legislature

93 Dinah Shelton, Introduction to COMMITMENT AND COMPLIANCE: THE ROLE OF NON-BINDING NORMS IN THE INTERNATIONAL LEGAL SYSTEM 2-4, 10-13 (Dinah Shelton ed., 2000); Kenneth W. Abbott \& Duncan Snidal, Hard and Soft Law in International Governance, 54 INT'L ORG. 421, 434 (2000).

94 The legislative process is one in which legislators work to pursue legislation that they and/or their constituents desire. The motivation may be ideological and/or may be a function of a legislator's attempt to win reelection. There is a large existing literature on the motivation and the structure of the legislative process. See, e.g., Mueller, supra note 36, at 386-405; POSITIVE TheORIES OF 
thus may be an engine of liberalization. In liberalization, a country reduces its government-imposed barriers to competition. For example, beginning in the 1970 s, the U.S. Congress liberalized a number of sectors, such as energy, transportation, and financial services. ${ }^{95}$ On a global level, the period of the 1980s and 1990s witnessed unrivaled cross-country regulatory liberalization. Countries increasingly abandoned (in part or in whole) centralized planning and government ownership of companies for private ownership and market-based economies. ${ }^{96}$

A market-based economy requires setting up an appropriate regulatory framework and mechanisms, providing remedies for anticompetitive conduct, and eliminating market failures. To facilitate liberalization and to constrain retrenchment of previous policies, legislators increasingly have looked to sector-based regulatory systems and to antitrust law. ${ }^{97}$ The emerging empirical record on liberalization suggests that overall this process has led to increased efficiency. ${ }^{98}$ Moreover, increased liberalization has led to increased long-term investment. ${ }^{99}$

An additional legislative response for reducing public restraints is trade liberalization. ${ }^{100}$ Increased trade openness may reduce rent-seeking public restraints because openness creates new constituencies for economic liberalization. ${ }^{101}$ Increased foreign competition leads to increased institutional quality because firms in a competitive environment become demandeurs for improved institutional quality. ${ }^{102}$

CONGREssional Institutions (Kenneth A. Shepsle \& Barry R. Weingast eds., 1995); THE OXFORD

HANDBOOK OF POlitiCAL ECONOMY (Barty R. Weingast \& Donald A. Wittman eds., 2006).

95 STEPHEN BREYER, REGULATION AND ITS REFORM 194 (1982).

96 D. Daniel Sokol, Order Without (Enforceable) Law: Why Countries Enter into NonEnforceable Competition Policy Chapters in Free Trade Agreements, 83 CHI.-KENT L. REV. 231, 23639 (2008).

97 How exactly efforts at reform overcame public choice problems remains under-explored. See $i d$. at 243 (arguing that international lending institutions and trade agreements contributed to this change); Todd J. Zywicki, Environmental Externalities and Political Externalities: The Political Economy of Environmental Regulation and Reform, 73 TUL. L. REV. 845, 915 (1999) ("Deregulation, therefore, may come about only if the distributive consequences to entrenched interest groups and politicians is large enough to offset the rents they are sacrificing.").

98 William L. Megginson \& Jeffry M. Netter, From State to Market: A Survey of Empirical Studies on Privatization, 39 J. ECON. LIT. 321, 332-37 (2001).

99 Alberto Alesina et al., Regulation and Investment, 3 J. EUR. ECON. ASS'N 791, 792 (2005).

100 Some countries may be too small to have an antitrust authority. Stefan Voigt, The Economic Effects of Competition Policy: Cross-Country Evidence Using Four New Indicators 20 (Int'1 Centre for Econ. Res., Working Paper No. 20, 2006), available at http://www.isnie.org/ISNIE06/Papers06/ 09.3/voigt.pdf.

101 Simon Johnson, Jonathan D. Ostry \& Arvind Subramanian, The Prospects for Sustained Growth in Africa: Benchmarking the Constraints 21 (Int'l Monetary Fund, Working Paper No. 07/52, 2007), available at http://www.imf.org/external/pubs/ft/wp/2007/wp0752.pdf.

102 Quy Toan Do \& Andrei A. Levchenko, Trade, Inequality, and the Political Economy of Institutions, 144 J. ECON. THEORY 1489, 1491 (2008); Andrei A. Levchenko, Institutional Quality and International Trade, 74 REV. ECON. STUD. 791, 792 (2007). 
Trade openness can help to address issues of market concentration in a country (at least in the tradable sector). Market concentration in itself does not equal market power. ${ }^{103}$ However, more highly concentrated markets may allow firms with a dominant position to have the means by which to monopolize. ${ }^{104}$ When markets are highly concentrated, firms may use their market power to create high entry barriers, such as trade barriers. In turn, such barriers may limit the ability of foreign entry (actual or potential) to reduce monopolistic practices. ${ }^{105}$ Individual firms may create anticompetitive vertical restraints to exclude foreign entrants. ${ }^{106}$ In contrast, increased trade openness may increase competition and reduce market concentration in the tradable sector. ${ }^{107}$

There are limits to using a trade liberalization/market access approach in lieu of antitrust regulation. The non-tradable sector of an economy may remain uncompetitive. Moreover, increased trade does not stop the possibility that firms may collude with each other to fix price, output, or service territories. ${ }^{108}$ There is an increasing recognition that trade openness and liberalization alone cannot remedy the potential for anticompetitive conduct. For instance, the two most liberalized and trade-open jurisdictions in the world, Hong Kong and Singapore, who for so long felt that the market alone could remedy any possible anticompetitive practices, have begun to introduce antitrust laws. ${ }^{109}$ To ensure the contestability of even the most liberalized national markets to trade, antitrust regulation serves a compli-

103 Simeon Djankov \& Bernard Hoekman, Conditions of Competition and Multilateral Surveillance, 21 WORLD ECON. 1109, 1116 (1998).

104 Wendy Carlin, Mark Schaffer \& Paul Seabright, A Minimum of Rivalry: Evidence from Transition Economies on the Importance of Competition for Innovation and Growth, 3 CONTRIBUTIONS ECON. ANALYSIS \& POL'Y 1, 17 (2004) available at http://www.bepress.com/cgi/viewcontent.cgi?article=1284 \&context=bejeap (subscription required) (finding that where firms are more likely to be monopolies, they are less likely to innovate and more likely to have weaker growth than firms that face business rivalry).

105 See Oliver Budzinski, Toward an International Governance of Transborder Mergers? Competition Networks and Institutions between Centralism and Decentralism, 36 N.Y.U. J. INT'L L. \& POL. 1, 4 (2003).

106 Stephen F. Hamilton \& Kyle Stiegert, Vertical Coordination, Antitrust Law, and International Trade, 43 J.L. \& ECON. 143, 150-51 (2000).

107 Todd Mitton, Institutions and Concentration, 86 J. DEV. ECON. 367, 368 (2008) (noting that this is particularly an issue in smaller economies that by definition have more highly concentrated markets).

108 Julian L. Clarke \& Simon J. Evenett, The Deterrent Effects of National Anticartel Laws: Evidence from the International Vitamins Cartel, 48 ANTITRUST BULL. 689, 697 (2003); Margaret Levenstein \& Valerie Y. Suslow, Contemporary International Cartels and Developing Countries: Economic Effects and Implications for Competition Policy, 71 ANTITRUST L.J. 801, 819 (2004).

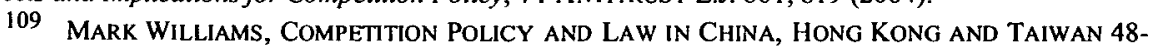
49, 71, 264 (2005); Burton Ong, The Origins, Objectives and Structure of Competition Law in Singapore, 29 WORLD COMPETITION 269, 270 (2006). 
mentary role to trade liberalization in ensuring that private restraints do not replace public restraints. ${ }^{110}$

As the prime mover of economic liberalization, the legislature faces structural impediments more severe than other institutions. The problem of time inconsistency, in which the make-up of legislators change, may lead to policies that deviate from those of the initial enacting coalition, and makes the legislature less effective than other alternatives in preserving the gains of liberalization. ${ }^{111}$ Checks and balances are fewer in a legislature than for independent actors, such as administrative agencies or the judiciary. ${ }^{112}$ This makes legislatures relatively more prone to capture. Moreover, legislation is often written in broad, imprecise terms. The vagueness of legislation leaves it to agencies and courts to decide the scope of legislation. ${ }^{113}$

\section{Sector Regulators}

Sector regulation is a potential domestic agency-level response to public restraints. Sector regulation generally involves ex ante enforcement. ${ }^{114}$ In some cases, the goal of sector regulation is to address market failure

110 Bernard Hoekman \& Hiau Looi Kee, Competition Law as Market Discipline, (2002), available at http://papers.ssrn.com/sol3/papers.cfm?abstract_id=320282; Leon Brittan, Address at the World Competition Forum in Davos, Switzerland: A Framework for International Competition (Feb. 3, 1992).

111 David Epstein \& Sharyn O'Halloran, Divided Government and the Design of Administrative Procedures: A Formal Model and Empirical Test, 58 J. POL. 373, 379-81 (1996). To be sure, the nature of legislative relations also depends on the system of govemment. The particular dynamics may look different in presidential versus parliamentary systems.

112 Markus M.L. Crepaz, Global, Constitutional, and Partisan Determinants of Redistribution in Fifteen OECD Countries, 34 COMP. POL. 169, 174 (2002).

113 A principal-agent problem may develop in legislation in which the agent (courts or agencies) may pursue goals different from that of the principal. KENNETH A. SHEPSLE \& MARK S. BONCHEK, ANALYZING POLITICS: RATIONALITY, BEHAVIOR, AND INSTITUTIONS 358-68 (1997).

114 Damien Geradin \& Michel Kerf, CONTROlling Market Power IN TELECOMMUNICATIONS 17 (2003). The rationale for utilizing sector regulation over antitrust regulation is that sector regulation has greater expertise than antitrust to address sector-specific competition issues. OECD, The Relationship Between Competition Authorities and Sectoral Regulators 4, OECD Doc. OECD DAF/COMP/GF(2005)2 (Feb. 2, 2005), available at http://www.ictregulationtoolkit.org/ en/Publication. 1626.html. For example, in the case of telecommunications, a telecom regulatory regime is more effective than is an antitrust-based regime in technical areas such as number portability or in setting effective interconnection rates. Likewise, antitrust seems less well suited than telecom regulators to pursue structural remedies such as vertical separation, universal service obligations, or merger review where no competition previously existed. Michel Kerf, Isabel Neto \& Damien Géradin, Controlling Market Power: Balancing Antitrust and Sector Regulation in Telecoms, WORLD BANK PUB. POL'Y J., June 2005, at 3-4, available at http://rru.worldbank.org/publicpolicyjournal.com (providing case studies of the United States, Australia, New Zealand, Chile, and the United Kingdom). In contrast, antitrust law may be applied more consistently across a number of different areas of the economy. This consistency may provide for better business decision-making in terms of business planning, as opposed to having different standards for competition depending on the particular sector of the economy. 
through market-facilitating measures. ${ }^{115}$ However, in many countries sector regulators have their origin in a market replacement function rather than in a market facilitation function. These sector regulators may have difficulty in making a transition to a market facilitation function because of their history, past interactions with the legislature, and interactions with those companies that they regulate.

Sector regulators are more likely to have multiple missions than antitrust agencies. Whereas efficiency may, in practice, be the sole mission of antitrust regulation, sector agencies may need to balance efficiency concerns with the preservation of competitors who provide diversity of number of firms or, in some instances, preserve a diversity of viewpoints. ${ }^{116}$ Sector regulation may also include requirements for the supply and/or quality of service, depending on the sector. Strategic factors may play a role in how sector regulators choose to regulate, given overall political economy concerns. Local firms in network industries may be a large portion of a local stock exchange. Regulation that encourages competition may negatively affect a local stock market. In countries in which pension plans have a large local stock market component, the potential economic consequence of greater efficiency that reduces the stock market value of a monopolist may be significant. ${ }^{117}$

Sector regulators may be less inclined to take on risk. ${ }^{118}$ Risk averse behavior is more predictable than behavior that requires risk taking by managers or regulators. It allows sector regulators to maintain their political capital. ${ }^{19}$ This is a public choice problem because innovation by agencies can lead to political backlash. Funding may be cut as retribution for policies that create costs to entrenched interest groups, even when such policies are consumer welfare enhancing. A second element to risk aversion by regulators is that regulators may not want to promote structural reforms that would expand competition in the sector and have the market serve as the default institution. By increasing competition, the size, role, and responsi-

115 Jean-Jacques Laffont, Competition, Information, and Development 6 (Annual World Bank Conference on Dev. Econ., 1998), available at http://siteresources.worldbank.org/ INTABCDEWASH INGTON1998/Resources/laffont.pdf.

116 Howard A. Shelanski, Antitrust Law as Mass Media Regulation: Can Merger Standards Protect the Public Interest?, 94 CAL. L. REv. 371, 394 (2006). What antitrust means by claims of efficiency is still open to debate. See, e.g., Karl Aiginger, et al., Do American and European Industrial Organization Economists Differ?, 19 REV. INDUS. ORG. 383, 384 (2001); Eleanor M. Fox, What Is Harm to Competition? Exclusionary Practices and Anticompetitive Effect, 70 ANTITRUST L.J. 371, 372 (2002).

117 Manabu Asai \& Tsunemasa Shiba, The Japanese Stock Market and the Macroeconomy: An Empirical Investigation, 2 FIN. ENGINEERING \& JAPAN. MKTS. 259, 259 (1995); Gene Park, The Political-Economic Dimension of Pensions: The Case of Japan, 17 GOVERNANCE 549, 561 (2004).

118 Sam Peltzman, An Evaluation of Consumer Protection Legislation: The 1962 Drug Amendments, 81 J. POL. ECON. 1049, 1086 (1973).

119 Zywicki, supra note 81 , at 9. 
bility of the regulator could be diminished as the market (and antitrust as a check on market malfunctions) takes over more oversight functions. ${ }^{120}$

\section{Antitrust Agencies}

A focus on using antitrust agencies to combat public restraints is an institutional choice for a market-based approach, with antitrust regulation as the backstop to police against market failure. ${ }^{121}$ The central questions that antitrust law addresses are whether and when to intervene and when to leave economic regulation to the market. Antitrust law may intervene ex ante in merger review to block potentially anticompetitive mergers. ${ }^{122}$ Antitrust law also may intervene ex post when a firm exercises monopoly power or when firms collude to raise prices.

For antitrust law to be effective, the state must create mechanisms to constrain itself from manipulating the system to its own advantage and that of interest groups. ${ }^{123}$ Yet, as the discussion about other domestic institutions illustrates, the state has a number of weaknesses in reducing public restraints. Antitrust agencies have limited capacity to affect change, even with increased help from soft law organizations. ${ }^{124}$ This institutional limitation reduces antitrust agencies' effectiveness in addressing public restraints and even affects outcomes where antitrust law acts against private firm anticompetitive conduct.

120 Darryl Biggar \& Alberto Heimler, An Increasing Role for Competition in the Regulation of Banks 20 (ICN Antitrust in Regulated Sectors Subgroup 1, 2005), available at http://www.internationalcompetitionnetwork.org/media/library/conference_4th_bonn_2005/BankingAnIncreasingRoleForCompetition.pdf.

121 Cécile Aubert \& Jean-Jacques Laffont, Multiregulation in Developing Countries 44 (Background Paper for the World Dev. Report, 2002); Dennis W. Carlton \& Randal C. Picker, Antitrust and Regulation 16 (John M. Olin L. \& Econ. Working Paper No. 312 (2d series), 2006), available at http://papers.ssrn.com/sol3/papers.cfm?abstract_id=937020.

122 Some mergers do get challenged ex post but the vast majority of merger inquiry occurs before the merger has been consummated. See U.S. DEP'T OF JUSTICE, ANTITRUST DIV., ANTITRUST DIVISION POLICY GUIDE TO MERGER REMEDIES (Oct. 2004), available at http:/www.usdoj.gov/atr/public/ guidelines/205108.htm (outlining the "guiding principles" that lead the Division to challenge mergers in advance of their consummation).

123 Douglass C. North \& Barry R. Weingast, Constitutions and Commitment: The Evolution of Institutional Governing Public Choice in Seventeenth-Century England, 49 J. ECON. HIST. 803, 808 (1989) (discussing the role of the state and economic activity).

124 Michael Nicholson, D. Daniel Sokol \& Kyle W. Stiegert, Technical Assistance for Law and Economics: An Empirical Analysis in Antitrust/Competition Policy 1 (Food Sys. Research Group, Univ. of Wis.-Madison, Working Paper Series FSWP2006-07, 2006), available at http://www.aae.wisc.edu/ fsrg/publications/WP2006-07.pdf. 
To combat public restraints, effective antitrust regulation requires coordination among different parts of government. ${ }^{125}$ Consequently, the coordination and political costs for agencies that combat public restraints are high. The pragmatic approach taken by many young antitrust agencies is to focus on the "low hanging fruit" of antitrust regulation where effective results are easier to achieve. This entails an initial focus on cartel enforcement and basic competition advocacy. Once an agency gains sufficient expertise and experience in this area, it can add merger review and vertical restraints to its enforcement agenda. Only after an agency masters these areas will it engage in competition advocacy in the area of regulation. ${ }^{126}$ For many agencies, it may be many years before they reach the final stage of advocacy of the elimination of regulatory barriers that include immunities. These priorities appear to be the dominant views held by the antitrust establishment. ${ }^{127}$ Given an increasing international focus on hard-core cartel enforcement by domestic agencies, the resources given to combating public sector restraints may be rather limited in young antitrust agencies.

Such an environment presents a limited ability for antitrust agencies to combat public restraints through domestic antitrust institutions. Thus, even though public restraints may be important, within the traditional path of antitrust agency development, they are not a priority. ${ }^{128}$ By the time domestic agencies develop the ability to attack public restraints, including immunities, these restraints may take on a life of their own, with strong interest groups attached to their preservation and expansion. This suggests that the lag time for a purely domestic enforcement of public restraints creates significant harm both domestically and abroad, as the restraints may grow over time.

125 Michal S. Gal, The Ecology of Antitrust Preconditions for Competition Law Enforcement in Developing Countries (N.Y.U. Law \& Econ. Research Paper Series, Working Paper No. 02-03, 2004), available at $\mathrm{http}: / / \mathrm{ssm} . \mathrm{com} / \mathrm{abstract}=665181$. This is not to suggest that antitrust systems are close to the appropriate level of cooperation and coordination. For example, the U.S. system is comprised of fiftyone state attorneys general, two federal antitrust agencies, private litigants, sector regulators, a nonantitrust specialized judiciary, and legislators.

126 Robert Anderson \& Frédéric Jenny, Competition Policy, Economic Development and the Possible Role of a Multilateral Framework on Competition Policy: Insights from the WTO Working Group on Trade and Competition Policy, in COMPETITION POLICY IN EAST ASIA 61, 66 (Erlinda M. Medalla ed., 2005); Report (1998) of the Working Group on the Interaction between Trade and Competition Policy to the General Council 151 , No. WT/WGTCP/2 (Dec. 8, 1998), available at http://docsonline.wto.org/ DDFDocuments/t/WT/WGTCP/2.doc.

127 Gerald F. Masoudi, Deputy Assistant Att'y Gen., U.S. Dep't of Justice, Antitrust Div., Intellectual Property and Competition: Four Principles for Encouraging Innovation, Address Before the Digital Americas 2006 Meeting (Apr. 11, 2006), available at http://www.usdoj.gov/atr/public/speeches/ 215645.pdf.

128 See, e.g., William J. Kolasky, Deputy Assistant Att'y Gen., U.S. Dep't of Justice, Antitrust Div., North Atlantic Competition Policy: Converging Toward What?, Address at the BIICL Second Annual International and Comparative Law Conference (May 17, 2002), available at http://www.usdoj.gov/atr/public/speeches/ 224128.htm. 
Antitrust agencies can reduce public restraints through competition advocacy. ${ }^{129}$ Through competition advocacy, antitrust agencies may intervene outside of cases either ex ante or ex post to shape regulation, promote the organization of a market-oriented economic system, and reduce public restraints. Domestic competition advocacy by antitrust agencies creates a counterweight to domestic interest groups. "Antitrust is not a cure for rentseeking, but it can make important contributions to addressing the problem." "130 Competition advocacy can be focused directly towards government restraints when an antitrust agency makes submissions in administrative rulemakings or the legislative process to safeguard competitive process. Competition advocacy takes a number of forms, including direct advocacy, constituency development, research, and studies. ${ }^{131}$ These policies enable antitrust agencies to advocate against anticompetitive laws and regulations by unmasking their societal costs. ${ }^{132}$ In one recent example, the FTC authored a report on the U.S. Postal Service that demonstrated that both federal and state laws apply more favorably to the Postal Service than to its private competitors. The FTC advocated eliminating the disparate treatment. ${ }^{133}$

While government agencies, private companies, and industries have the resources to spend on lobbying, consumers lack the resources to undertake such advocacy on their own. Where these interest groups create anticompetitive regulation through immunities, anticompetitive legislation and regulation are placed beyond the reach of traditional antitrust enforcement. Competition advocacy creates a role for antitrust agencies in the influence of other government agencies. Because antitrust agencies have no direct authority, they are more likely to be able to avoid capture. Antitrust regulation addresses economy-wide issues, making capture of an antitrust agency by a particular industry less likely than in the case of sector regulators. $^{134}$

\footnotetext{
129 Maurice E. Stucke, Better Competition Advocacy, 82 ST. JOHN'S L. REV. 951,953 (2008).

130 Timothy J. Muris, Looking Forward: The Federal Trade Commission and the Future Development of U.S. Competition Policy, 2003 COLUM. BUS. L. REv. 359, 368.
}

131 William E. Kovacic, Institutional Foundations for Economic Legal Reform in Transition Economies: The Case of Competition Policy and Antitrust Enforcement, 77 CHI.-KENT L. REV. 265, 282-84 (2001); Timothy J. Muris, Chairman, Fed. Trade Comm'n, Creating a Culture of Competition: The Essential Role of Competition Advocacy, Address Before the International Competition Network Panel on Competition Advocacy and Antitrust Authorities (Sept. 28, 2002), available at http://www.ftc.gov/ speeches/muris/020928naples.shtm.

132 But see Simon J. Evenett, Competition Advocacy: Time for a Rethink, 26 Nw. J. INT'L L. \& Bus. 495, 500-07 (2006) (examining and critiquing the rationales behind competition advocacy).

133 FED. TRADE COMM'N, ACCOUNTING FOR LAWS THAT APPLy DIFFERENTLY TO THE UNITED States Postal Service and its Private Competitors: A Report By the Federal Trade COMMISSION 10-11 (Dec. 2007), available at http://www.ftc.gov/os/2008/01/080116postal.pdf.

134 Biggar \& Heimler, supra note 120, at 19-20. 
Nevertheless, antitrust agency advocacy has somewhat limited value. Limited agency resources constrain advocacy efforts. Antitrust agencies allocate limited funding for advocacy in part because advocacy work is not enforcement and politicians that control agency purse strings do not attach as much value to fighting against anticompetitive harm that was never undertaken than to efforts to end ex post anticompetitive abuses. Moreover, advocacy work on public restraints may affect antitrust agency funding because of the potential political backlash, despite the legitimate questions about government-sponsored programs that benefit special interests at the expense of consumers.

\section{Judiciary}

The judiciary plays a critical role in the implementation of competition through judicial review of antitrust agency determinations. ${ }^{135}$ Through judicial review of agency actions, the judiciary has powers to ensure that agency actions are upheld and enforced through the collection of penalties. ${ }^{136}$ The judiciary's ability to impose effective antitrust remedies goes to the heart of the judiciary's relative competency to address public restraints. This task is to undertake analyses and craft remedies that limit public restraints and restore competition.

There are limits to the use of the judiciary for antitrust in general and for public restraints in particular. Considerations of the substantive ability of adjudicative decision-makers, the dynamics of litigation, and the physical capacity of adjudication determine the strength or weakness of the adju-

135 William E. Kovacic, Getting Started: Creating New Competition Policy Institutions in Transition Economies, 23 BROOK. J. INT'L L. 403, 407 (1997). Another issue of an institutional choice of the judiciary focuses on who can participate in the judicial process and bring claims. In some countries, private litigants can bring claims while in most antitrust systems, only government enforcers can bring antitrust cases before the courts. Ilya R. Segal \& Michael D. Whinston, Public vs. Private Enforcement of Antitrust Law: A Survey 1 (John M. Olin Program in Law \& Econ., Stanford Law School, Working Paper No. 335, 2006), available at http://ssm.com/abstract $=952067$ (providing a literature review on private rights). Private rights of action may work to overcome regulatory capture by taking away discretion from an agency that might choose not to take on politically difficult cases. This may also limit agency interventions because there is the possibility for private actors to bring novel claims for anticompetitive conduct. However, private rights may lead to too many frivolous and/or strategic lawsuits. R. Preston McAfee \& Nicholas V. Vakkur, The Strategic Abuse of the Antitrust Laws, 1 J. STRATEGIC MGMT. EDUC. 1, 3 (2004); William J. Baumol \& Janusz A. Ordover, Use of Antitrust to Subvert Competition, 28 J.L. \& ECON. 247, 247-48 (1985); William Breit \& Kenneth G. Elzinga, Private Antitrust Enforcement: The New Learning, 28 J.L. \& ECON. 405, 412-13 (1985). In countries that address only private restraints of trade through their antitrust laws, such as the United States, private rights cannot attack public restraints.

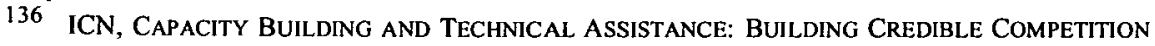
AUTHORITIES IN DEVELOPING AND TRANSITION ECONOMIES 36 (2003). 
dicative process. ${ }^{137}$ The judiciary of a country may not be well-versed in the core concepts of antitrust and economic law. ${ }^{138}$ Cross-country experience suggests that courts have limits in their ability to adjudicate highly technical regulatory issues. ${ }^{139}$ A system in which the judiciary acts as a bottleneck to enforcement creates a situation which effectively condones anticompetitive conduct. Developing judicial expertise in economic law in general, and antitrust law specifically, is important to ensure appropriate enforcement of the development of a functioning, market-based legal infrastructure.

Antitrust litigation produces regulatory uncertainty because different courts may rule inconsistently with the same set of facts. Anecdotal evidence indicates that when courts do not understand complex antitrust issues, they rule based on a highly procedural formalism. ${ }^{140}$ These problems of procedural formalism in antitrust decisions create particular concerns in conduct cases or with regard to penalties for conduct, regardless of the origin of the legal system. ${ }^{141}$ For example, in New Zealand, telecommunications regulation focused on a general antitrust solution in conjunction with courts rather than with sector regulation. ${ }^{142}$ In a case involving interconnection rates within telecommunications between the incumbent provider and a new entrant for access to the local loop, the case took five years to decide, with significant procedural delay. ${ }^{143}$ The lack of the New Zealand judicial system's understanding of the complex pricing issues and methodologies for interconnection underlying the case meant that the conflicting court decisions left little certainty-none of the courts came up with a specific interconnection price. This enabled the incumbent Telecom Corporation to maintain its monopoly position, and it left the victims of its anticompetitive behavior without any effective means of redress. ${ }^{144} \mathrm{~A}$ similar problem occurred in Chile, where the Chilean Supreme Court recently overruled the Chilean Competition Tribunal in cases regarding tacit collusion based on procedural rather than substantive grounds, and where it seemed apparent that the Supreme Court did not understand the antitrust issues. ${ }^{145}$

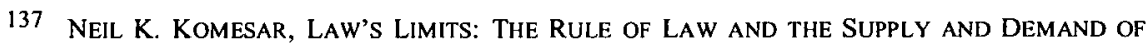
RIGHTS 35 (2001).

138 ICN, Competition and the Judiciary 19 (ICN Competition Policy Implementation Working Group, 2007), available at http://www.internationalcompetitionnetwork.org/media/library/conference 6th_moscow_2007/12ReportontheCompetitoinandtheJudiciary.pdf [hereinafter ICN, Competition and the Judiciary]; Baye \& Wright, supra note 62, at 6.

139 Aubert \& Laffont, supra note 121, at 44.

140 ICN, Competition and the Judiciary, supra note 138, at 17

141 Id. at 4.

142 GERADIN \& KERF, supra note 114, at 119-62.

143 Id.

144 Carl Blanchard, Telecommunications Regulation in New Zealand: Light-handed Regulation and the Privy Council's Judgment, 19 TELECOMM. POL'Y 465, $472-73$ (1995).

145 Elina Cruz \& Sebastian Zarate, Building Trust in Antitrust: The Chilean Case, in COMPETITION LAW AND POLICY IN LATIN AMERICA 157, 168, 178 (Eleanor M. Fox \& D. Daniel Sokol eds., 2009). 
As part of competition advocacy, antitrust agencies try to limit judicial overreach by training the judiciary and by producing briefs in litigation that stress the importance of a limited judicial reach of decisions. Construing legislation should be approached as a public choice problem. According to Judge Frank Easterbrook, legislation reflects a particular bargain and not more. ${ }^{146}$ A narrow construction of an exemption takes into consideration the public choice view that interest groups can contort the legislative process to extract rents from legislation. If courts around the world followed the advice of Easterbrook, there would be fewer judicially-created public restraints. ${ }^{147}$ However, the history of public restraints suggests that many courts take an approach opposite to that advocated by Easterbrook.

\section{International Institutional Choices}

The limited ability of domestic institutions to effectively address public restraints suggests the potential importance of international institutional alternatives. To address problems that affect multiple jurisdictions, countries should create international cooperative solutions. ${ }^{148}$ International institutions may also be better suited to create domestic compliance through norm creation and to overcome domestic political economy concerns that allow for the creation and preservation of antitrust immunities. Moreover, because of the amount of time it takes young agencies to become effective at competition advocacy, the scope of the harm of public restraint immunities may justify greater internationalization of solutions.

\section{Soft Law}

Antitrust soft law focuses on greater harmonization of national laws through international institutions using norm creation. ${ }^{149}$ Because of their non-binding nature, soft law institutions may allow for greater flexibility

146 Frank H. Easterbrook, Foreword: The Court and the Economic System, 98 HARV. L. REV. 4, 46 (1984) ("When a court observes that Congress propelled Group $X$ part way to its desired end, it cannot assist Group $X$ farther along the joumey without undoing the structure of the deal.").

147 J. MARK Ramseyer \& ERIC B. Rasmusen, MEASURING JUdicial INDEPENDENCE: THE POLITICAL ECONOMY OF JUDGING IN JAPAN $3-4$ (2003) (suggesting that judges may not be insulated politically in their decision-making, making them subject them to capture).

148 R.H. Coase, The Problem of Social Cost, 3 J.L. \& ECON. 1, 17-18 (1960). For Coasian formalizations of federalism to overcome state problems in bargaining, see Steven G. Calabresi, " $A$ Government of Limited and Enumerated Powers": In Defense of United States v. Lopez, 94 MICH. L. REV. 752 , 784-85 (1995); Thomas W. Merrill, Golden Rules for Transboundary Pollution, 46 DUKE L.J. 931, 935 (1997).

149 Although antitrust norms are not entirely dependent on intemational institutions, without such soft law institutions these antitrust norms would not have spread nearly as fast. 
than international hard law. ${ }^{150}$ To a larger extent than hard law, soft law relies on domestic institutions for compliance. ${ }^{151}$ Without effective domestic enforcement, soft law is not effective in creating commitments that countries will undertake and enforce. Soft law, therefore, must respond to the limitations of the domestic environments in which it operates, the better to set an agenda and achieve results. In the antitrust setting specific to public restraints, soft law helps improve the capacity of antitrust agencies to identify anticompetitive behavior, to successfully bring cases, and to undertake competition advocacy.

Two forms of soft law institutions impact antitrust regulation: transgovernmental and transnational institutions. Transgovernmentalism allows for international interaction at the sub-state level between administrative agencies across jurisdictions. ${ }^{152}$ In transgovernmentalism, regulatory agencies establish common practices and norms, which they then diffuse domestically. There are two global transgovernmental organizations in international antitrust law, the OECD and UNCTAD, discussed infra. The transnational structure includes agency level decision-makers along with nongovernmental stakeholders. ${ }^{153}$ These stakeholders include academics, members of the business community, and civil society groups. Among antitrust institutions, the ICN (as detailed in the next section) uses a transnational organizational structure. Transnational participation by non-governmental stakeholders may reduce the cost of information more than transgovernmental structures because the broad group of stakeholders can provide input and guidance to addressing the problems of public restraints. In these circumstances, users of antitrust law can help to shape the regulation and enforcement of anticompetitive conduct including public restraints. ${ }^{154}$

Soft law institutions create compliance through the benchmarking of norms. In benchmarking, members of an organization will compare their respective regulatory systems and determine those elements in which there is consensus as to effective approaches within the accepted "benchmarked" norms. Put differently, this process of benchmarking allows for the creation of "better" practices and implementation by antitrust agencies. ${ }^{155}$ Bench-

\footnotetext{
150 Kenneth W. Abbott \& Duncan Snidal, Hard and Soft Law in International Governance, 54 INT'L ORG. 421,434 (2000).

151 Eleanor M. Fox, Global Problems in a World of National Law, 34 NEw ENG. L. REV. 11, 13 (1999).

152 Anne-Marie Slaughter, The Real New World Order, 76 FOREIGN AFF. 183, 184-86 (1997).

153 Thomas Risse-Kappen, Introduction to BRINGING TRANSNATIONAL RELATIONS BACK IN: NONSTATE ACTORS, DOMESTIC STRUCTURES AND INTERNATIONAL INSTITUTIONS 3 (Thomas Risse-Kappen ed., 1995).

154 Sokol, supra note 5, at 107.

155 Better practices may be a preferable term as practices evolve over time. With advances in thinking and a number of iterations of better approaches, new approaches may emerge that may be more effective. See generally William E. Kovacic, Achieving Better Practices in the Design of Competition
} 
marking sets the standard for acceptable behavior and approaches for antitrust agencies. It also provides flexibility for particular agencies to fit within a larger norm while preserving their ability to act given their own unique legal and institutional settings.

Because soft law can be more ambiguous than hard law, it is easier to reach acceptance based on general principals. This same ambiguity may allow for greater compromise among actors and encourage more cooperation among agencies. For example, in antitrust regulation, benchmarking on public restraints might focus on issues such as ensuring transparency of regulations, applying sound economic analysis in enforcement decisions, and ensuring that the antitrust law allows for effective remedies for anticompetitive behavior against public restraints.

Compliance with soft law norms and benchmarking sometimes requires the domestic legislature to play a role to change laws to conform to international norms. The international mandate for change based on internationally established better practices may help to enact such reforms domestically. Soft law effectiveness may also have an effect on hard law. If soft law creates increased domestic compliance, this enables better implementation of hard law, or creates higher standards for hard law based on the emerging norms. ${ }^{156}$ As economic learning in antitrust develops, soft law allows for integration of this learning by member agencies and non-agency actors in domestic antitrust systems. ${ }^{157}$ Through this process, shared norms may be redefined through additional iterations of discussions on implementation with new approaches. ${ }^{158}$

In developing accepted informal norms of behavior, soft law has had long-lasting effects in antitrust regulation. Antitrust norm creation primarily has focused on cartels and mergers, where the primary problem is one of coordination across antitrust authorities. ${ }^{159}$ The norms created focus on es-

Policy Institutions, in ON THE MERITS: CURRENT ISSUES IN COMPETITION LAW AND POLICY 195 (Paul Lugard \& Leigh Hancher eds., 2005).

156 Jon Birger Skjærseth, Olav Schram Stokke \& Jørgen Wettestad, Soft Law, Hard Law, and Effective Implementation of International Environmental Norms, GLOBAL ENVTL. POL., Aug. 2006, at 104,105 (2006).

157 William E. Kovacic \& Carl Shapiro, Antitrust Policy: A Century of Economic and Legal Thinking, $14 \mathrm{~J}$. ECON. PERSP. 43, 58 (2000) (arguing that antitrust is evolutionary).

158 Charles F. Sabel \& Jonathan Zeitlin, Active Welfare, Experimental Governance, Pragmatic Constitutionalism: The New Transformation of Europe 2 (Draft Prepared for the Int'l Conference of the Hellenic Presidency of the EU, 2003), available at http://www.eucenter.wisc.edu/OMC/Papers/EUC/ zeitlinSabel3.pdf.

159 OECD, Recommendation of the Council Concerning Effective Action Against Hard Core Cartels 2, OECD Doc. C(98)35/FINAL (1998), available at http://www.oecd.org/dataoecd/39/4/2350130. pdf; OECD, Recommendation of the Council on Merger Review, OECD Doc. C(2005)34 (2005), available at http://www.oecd.org/dataoecd/3/41/40537528.pdf; OECD, Best Practices for the Formal Exchange of Information Between Competition Authorities in Hard Core Cartel Investigations 2 (Oct. 2005), available at http://www.oecd.org/dataoecd/1/33/35590548.pdf; ICN, Recommended Practices for Merger Notification Procedures 29 (ICN Conference, Sept. 2002), available at 
tablishing benchmarks for practices on the process of merger control, including issues of timing and transparency. In cartels, norms include identifying cartel behavior and setting up coordination mechanisms across countries. In both mergers and cartels, both developed- and developing-world antitrust agencies have implemented these benchmarked norms into their own laws and practices. ${ }^{160}$

Generally, there is no similar international consensus on the solution to the specific problem of public restraints. Moreover, existing substantive standards for addressing public restraints vary from country to country. Because of the variance in domestic substantive standards, which often leave a significant regulatory gap in the remedy of anticompetitive public restraints, the initial structure of any international response and its potential substantive standard is critical. This also increases the difficulty of determining an appropriate substantive standard, given the disagreement about what the most effective way to address antitrust public restraints is.

\section{a. Organization for Economic Co-operation and Development}

Over the years, the OECD has spent considerable resources studying antitrust public restraints. At OECD Competition Law and Policy Committee meetings, agencies discuss the reports that OECD staff write for a given issue and case studies that agencies submit on a topic. This sort of repeated interaction among agencies is meant to identify commonalities in approaches and make personal and agency-level connections between regulators across jurisdictions. Over time, OECD work products and meetings create antitrust enforcement and conceptual norms that can be diffused at the domestic level to fight public restraints. The OECD's strength is in its ability to take stock of existing laws and regulations of countries and to provide a synthesis of its findings for OECD members. This stocktaking has had an impact on other organizations. For example, the ICN has relied on OECD reports and other work product in a number of its documents. ${ }^{161}$

The OECD has, in recent years, examined antitrust immunities and public restraints. For example, at the 2006 Global Forum on Competition, agencies discussed a report on concessions (in which public restraints often

http://www.internationalcompetitionnetwork.org/media/library/conference_lst_naples_2002/speech gdz.pdf.

160 Mariana Bode \& Oliver Budzinski, Competing Ways Towards International Antitrust: The WTO Versus the ICN 3 (Marburg Papers on Econ., Working Paper No. 03-2005, 2005).

161 See, e.g., ICN, REPORT OF THE ICN WORKING GROUP ON TELECOMMUNICATIONS SERVICES (May 3, 2006), available at http://www.internationalcompetitionnetwork.org/media/library/conference 5th_capetown_2006/Reportofthe_Telecoms_WorkingGroup.pdf; ICN, Co-operation Between Competition Agencies in Cartel Investigations (Int'l Competition Network Cartels Working Group, May 2006), available at http://www.internationalcompetitionnetwork.org/media/library/conference_5th_capetown 2006/CompetitionAgenciesInCartelInvestigations.pdf; Biggar \& Heimler, supra note 120. 
play a role). The report focuses on how antitrust regulation should address competition issues in this area. The report includes both a report by the OECD Secretariat and comments by eleven agencies. ${ }^{162}$ Similarly, a 2009 report entitled "Competition Policy, Industrial Policy and National Champions" surveyed how countries address government preferences for national champions that may affect competition. ${ }^{163}$ Moreover, the work of a nowdisbanded OECD Joint Group on Trade and Competition focused on the trade-related public restraints interface. ${ }^{164}$

Specific to addressing public restraints, the weakness of the OECD is twofold. First, the OECD has not created any recommended practices specific to public restraints. Rather, the OECD has focused its non-binding resolutions on addressing enforcement issues that are based more on improving coordination across agencies and those that focus on substantive issues-hard-core cartels and merger control. ${ }^{165}$ In neither of these international antitrust areas is the restraint at question generally a public restraint; rather, both focus on restraints created by private parties. In merger control, the primary conduct is the potential merger or acquisition of two private parties. Likewise, in hard-core cartels the issue is a conspiracy to fix prices by (mostly) private competitors across jurisdictions.

The second, and more serious problem, is that the OECD lacks an effective compliance mechanism to produce enforcement by its members. ${ }^{166}$ The OECD Competition Law and Policy Committee requires sign-off by OECD member governments on proposed best practices. Nevertheless, many of these same governments are the very ones that have created immunities within their antitrust laws. Moreover, norm creation on the part of the OECD seems to be lethargic. It took nearly forty years-from the OECD Competition Law and Policy Committee's inception in 1961 to 1998before agreement could be reached on a recommendation of best practices

162 OECD, Global Forum on Competition: Roundtable on Concessions, OECD Doc. DAF/COMP/GF(2006)2 (Jan. 2006), available at http://www.oecd.org/dataoecd/6/48/42170273.pdf.

163 OECD, Industrial Policy, Competition Policy, and National Champions, OECD Doc. DAF/COMP/GF(2009)1/REV1 (Feb. 2009), available at http:/www.olis.oecd.org/olis/2009doc.nsf/ ENGDATCORPLOOK/NT00000A8A/\$FILE/JT03258931.PDF.

164 See, e.g., OECD, Consistencies and Inconsistencies Between Trade and Competition Policies, OECD Doc. COM/TD/DAFFE/ CLP(98)25/FINAL (Feb. 25, 1999); OECD, Competition and Trade Effects of Vertical Restraints, OECD Doc. COM/DAFFE/CLP/TD(99)54 (1999); OECD, Competition and Trade Effects of Abuse of Dominance, OECD Doc. COM/DAFFE/CLP/TD(2000)21/FINAL (Aug. 4, 2000).

165 OECD, Recommendation of the Council Concerning Effective Action Against Hard Core Cartels, OECD Doc. (98)35/FINAL (1998), available at http://www.oecd.org/dataoecd/39/4/2350130.pdf; OECD, Recommendation of the Council on Merger Review, OECD Doc. C(2005)34 (2005), available at http://webdominol.oecd.org/horizontal/oecdacts.nsf/linkto/c\%282005\%2934.

166 The OECD measures compliance via reports based on Council recommendations only, not of various discussion papers. See, e.g., OECD, HARD CORE CARTELS: THIRD REPORT ON THE IMPLEMENTATION OF THE 1998 RECOMMENDATION 7-8 (2005), available at http://www.oecd.org/ dataoecd/58/1/35863307.pdf. 
on hard-core cartels, even though international hard-core cartels had been an enforcement priority, at least for the United States, since the pre-World War II period. ${ }^{167}$ This suggests that the OECD may be of limited effectiveness in addressing the elimination of public restraints. Another problem may be substantive. Disagreement remains as to how much public restraints are a problem and on the different substantive approaches to combat them.

International power dynamics also affect the OECD's ability to combat public restraints. OECD membership shapes OECD dynamics and effectiveness. OECD members are developed-world antitrust agencies. In some cases, a number of developing-world agencies participate in OECD meetings and work products. However, it is the developed world, and in particular the United States and EU member states, that shape the agenda of the OECD. These enforcers shape the agenda of the OECD without significant non-governmental stakeholder participation. That is, non-government users of antitrust regulation do not have meaningful participation in the OECD, its work products, or its norm diffusion. This lack of participation makes norm diffusion more difficult at the domestic level. ${ }^{168}$

\section{b. United Nations Conference on Trade and Development}

UNCTAD is similar in structure and outputs to the OECD, but generally is less effective. UNCTAD's founding worldview helped to shape its tone in how the organization viewed competition policy. During its early period, UNCTAD championed a set of development policies known as the New International Economic Order ("NIEO"). ${ }^{169}$ The NIEO's purpose was to redress the international economic system in order to redistribute power and wealth from the developed world to the developing world. UNCTAD's overall agenda replicates itself somewhat in the antitrust arena, where UNCTAD serves as a voice for developing-world antitrust agencies, offering a more sympathetic voice to approaches not based on the dominant Chicago/Harvard antitrust model. ${ }^{170}$

167 Wyatt WElls, ANTITRUST AND THE FORMATION OF THE POSTWAR WORLD 27 (2002). However, the OECD does follow up on its recommendations by tracking the implementation across countries of recommended practices.

168 Sokol, supra note 5, at 100-01. However, OECD recommendations, because they are based on agreed norms, do create legitimacy and have an effect for changing domestic legislation.

169 Jagdish N. Bhagwati, THE NEW InTERnational ECONOMiC ORDER: THE NORTH-SOUTH DEBATE 3-4 (1977).

170 William H. Page, Areeda, Chicago, and Antitrust Injury: Economic Efficiency and Legal Process, 41 ANTITRUST BULL. 909, 910 (1996) (arguing that Chicago School thought is the baseline for antitrust in the United States); HERBERT HOVENKAMP, THE ANTITRUST ENTERPRISE: PRINCIPLE AND EXECUTION 37-38 (2005) (calling the fusion of Chicago analytical approach with Harvard antitrust concerns the "new Harvard" approach). 
Like the OECD, UNCTAD has addressed public restraints in a number of its documents and conferences. For example, one of its current projects is to better understand the relationship between antitrust agencies and sector regulators. It has developed a paper on best practices that identifies how to create increased cooperation between sector regulators and antitrust authorities to better limit public and mixed restraints. ${ }^{171}$ In another work product, UNCTAD analyzed antitrust immunities. ${ }^{172}$

UNCTAD's effectiveness in combating public restraints seems limited. First, UNCTAD work products seem not to have significant policy impact outside of the UNCTAD community. ${ }^{173}$ A second limitation on UNCTAD's effectiveness, like that of the OECD, involves issues of implementation and enforcement, rather than policy design and prescriptions. UNCTAD does little to follow up on its reports and peer reviews to measure and facilitate compliance with its recommendations.

The power asymmetries play out even more dramatically in the UNCTAD context than they do in the OECD context. Because UNCTAD is a developing-world-focused agency, the norms that it seeks to create on antitrust issues are limited by the countervailing power that developedworld countries use to push norms, technical assistance, and conferences. To the extent that UNCTAD norms are somehow different from developedworld norms (those of the European Commission and its member states, and the United States in particular), the lack of meaningful participation from the EU and United States in UNCTAD reduces the likelihood of adoption of UNCTAD norms by many UNCTAD members. ${ }^{174}$ Additionally, public restraints generally (though not necessarily specific to immunities) are more likely to be found in developing-world countries, as these countries have liberalized their economies less than developed-world countries.

171 UNCTAD Trade and Development Board, Best Practices for Defining Respective Competencies and Settling of Cases, Which Involve Joint Action by Competition Authorities and Regulatory Bodies 9, TD/RBP/CONF.6/13/Rev.1 (2006), available at http://www.unctad.ch/en/docs/tdrbpconf6d13rev1 en.pdf.

172 Khemani, supra note 14 , at 11-13.

173 It might not be surprising that UNCTAD documents do not get referenced in OECD documents. After all, there may be some institutional turf battles. The OECD may believe that since the most important antitrust agencies are active OECD members, UNCTAD has little to teach OECD. More telling is that not a single UNCTAD publication has been cited in ICN documents. Since the first step of the ICN is to take stock of the existing literature in antitrust to better determine where consensus may be reached, the omission of UNCTAD documents shows that UNCTAD has limited impact even in a forum that represents both developing- and developed-world interests (and in which UNCTAD participates).

174 The United States voted against U.N. General Assembly 59/221 in 2005 which linked antitrust to trade and development in which countries could set up antitrust systems "best suited to their development needs." G. A. Res. 59/221 ๆ 30, 59th Sess., U.N. Doc. A/Res/59/221 (Feb. 11, 2005), available at http:/daccessdds.un.org/doc/UNDOC/GEN/N04/489/52/PDF/N0448952.pdf?OpenElement. UNCTAD does not have high level international participation from the United States and EU in contrast to OECD and ICN meetings. 


\section{c. International Competition Network}

The ICN is a third international organization devoted to antitrust law. However, in its form and function, the ICN is distinct from both the OECD and UNCTAD. In at least two important ways, the ICN is stronger. First, the ICN encourages non-governmental stakeholder participation. Empirical work suggests that input in design by stakeholders leads to better performance outputs. ${ }^{175}$ In the antitrust context, users of antitrust systems help to shape the output of the ICN. These non-governmental stakeholders include academics, the business sector (companies, their outside lawyers and economists), and non-governmental organizations. Moreover, nongovernmental stakeholder participation includes both developed- and developing-world participants.

The use of non-state actors is a critical component to the ICN. This use is part of a broader increase in the role and impact of non-state actors generally across different areas of law. ${ }^{176}$ The participation of non-government stakeholders removes the insulation that antitrust agencies would have if they met only amongst themselves. The participation and interaction of different stakeholders shields against insulation by agencies that might ignore important information critical to achieving more effective results. ${ }^{177}$ Through their participation, private actors shape the nature and structure of their institutional environment. ${ }^{178}$ Such participation provides for important direct feedback loops to make corrections to policies. ${ }^{179}$

The second distinguishing feature of the ICN, relative to other international antitrust institutions, is that it is a virtual organization. This means that the ICN lacks a permanent bureaucracy. The lack of bureaucracy increases participation by agencies and non-government stakeholders since it reduces opportunities for free-riding off of the work of others. Without the support of all of these stakeholders, the ICN would cease to function. The lack of a permanent bureaucracy limits the potential for a bureaucratic dysfunction based on insulation or universalism. A large bureaucracy can lead

175 R. Edward Freeman, Strategic Management: A STakeholder ApproaCh (1984); Giles Slinger, Spanning the Gap-The Theoretical Principles That Connect Stakeholder Policies to Business Performance, 7 CORP. GOVERN. INT'L REV. 136, 138-39 (1999); Tom R. Tyler, Kenneth A. Rasinski \& Nancy Spodick, Influence of Voice on Satisfaction with Leaders: Exploring the Meaning of Process Control, 48 J. PERSONAlity \& SOC. Psychol. 72, 79 (1985); Nancy A. Welsh, Making Deals in CourtConnected Mediation: What's Justice Got To Do With It?, 79 WASH. U. L.Q. 787, 817-26 (2001).

176 Thomas Risse, Transnational Actors and World Politics, in HANDBOOK OF INTERNATIONAL RELATIONS 261, 262 (Walter Carlsnaes, Thomas Risse \& Beth A. Simmons eds., 2002).

177 Michael N. Barnett \& Martha Finnemore, The Politics, Power and Pathologies of International Organizations, 53 INT'L ORG. 699, 722 (1999); JAMES G. MARCH \& JOHAN P. OLSEN, REDISCOVERING InStITUTIONS: THE ORganizational Basis of Politics 3-4 (1989).

178 Christine Oliver, Strategic Responses to Institutional Processes, 16 ACAD. MGMT. REV. 145, 153 (1991); BEN ROSAMOND, THEORIES OF EUROPEAN INTEGRATION 114 (2000).

179 Barnett \& Finnemore, supra note 177 , at 723. 
to insulation in decision-making from alternative approaches. ${ }^{180}$ Bureaucrats may apply generalized knowledge inflexibly, even when particular circumstances may require a more contextual approach. ${ }^{181}$ The advantage of the virtual design of the ICN is that agencies can more easily take ownership of the various work products and outputs. This ownership makes it more likely that the ICN will be able to diffuse its norms to antitrust agencies and to other users of antitrust law. The increased number of participants in the ICN creates additional nodes for knowledge of the work products. This, in turn, creates institutional memory and more contact points for norm diffusion.

The ICN creates regulatory change through its various working groups. The purpose of each working group is four-fold: identify a problem for study; study the problem; present findings; and begin the process of harmonization. ${ }^{182}$ Through this process, as working groups build consensus on issues, momentum builds for increased harmonization on antitrust law and policy. ${ }^{183}$ This is not to suggest that there is convergence on a single standard. Rather, the approach identified for consensus positions allows for leeway based on the specific country situation of each agency.

In a number of working groups, the ICN has moved from analysis and norm creation to implementation. The steering group has pushed for early success of issues that it can solve. These issues are ones where some consensus can be established. ${ }^{184}$ This is a results-oriented agenda. The strength of the ICN has been in fostering procedural and coordination convergence, such as in mergers and cartels. ${ }^{185}$ The ICN has achieved some substantive results in those areas in which there is substantive agreement, such as cartels. In areas where there may be substantive disagreement, ICN findings for best practices have not been tested and the descriptive language of best practices is broad.

The working group most directly linked to the issue of public restraints is the Competition Policy Implementation ("CPI") Working Group. The CPI focuses its efforts on building institutional capacity among young antitrust agencies. ${ }^{186}$ The ICN has centralized many of its learning tools online

\footnotetext{
180 MARY DOUGLAS, HOW INSTITUTIONS THINK 24-25 (1986).

181 Barnett \& Finnemore, supra note 177, at 721

182 Sokol, supra note 5, at 109.

183 Merit E. Janow, Observations on Two Multilateral Venues: The International Competition Network (ICN) and the WTO, in INTERNATIONAL ANTITRUST LAW \& POLICY 2003, supra note 63, at 47

184 Consensus requires unanimity of ICN members. Any ICN member can block a recommended practice. Denmark held up one of the recommended merger practices based on concerns over the specific language, even in the face of EU and U.S. pressure to the contrary.

185 Oliver Budzinski, The International Competition Network: Prospects and Limits on the Road Towards Competition Governance, 8 COMPETITION \& CHANGE 223, 231 (2004); Sokol, supra note 5, at 106.

186 ICN, Competition Policy Implementation Working Group: Work Plan 2008-2009 (2008), available at http://www.internationalcompetitionnetwork.org/media/library/CPI/CPI_WG_2.pdf.
} 
to provide agencies easy reference to its materials for new antitrust agencies. Although within the CPI there has been no discussion of direct immunities as public restraints, public restraints discussion has arisen concerning indirect immunities in a number of different documents relating to implementation and competition advocacy. The capacity-building area has critical importance to public restraints. As agencies build up their capacity in enforcement and advocacy, they are better able to fight anticompetitive public restraints.

Previous work by the ICN focused on competition advocacy. A competition advocacy working group identified those elements of competition advocacy that have been effective and created more robust competition advocacy. Work focused in four areas: (1) Advocacy Information Center; (2) Model Advocacy Provisions; (3) Sector Studies; and (4) Practical Techniques. ${ }^{187}$ Each of these subgroups provided input as to experiences from successful competition advocacy. However, there are limitations to the impact of this work. Recently, the ICN resurrected this working group. In doing so it recognized the importance of competition advocacy to confront public restraints.

In contrast to the merger and cartel working groups, the CPI group has not yet created training sessions to increase domestic capacity for addressing public restraints. The ICN has yet to create a database of existing competition policy submissions, which could serve as templates that younger agencies may use to create their own policy. Such a database would reduce the time and information costs of drafting such advocacy papers. Public restraints-related work also lacks any follow-up from the ICN or private parties to determine how effective the ICN work has been to date in improving the capacity of agencies to fight public restraints. Private parties have funded studies in merger best practices implementation, but such parties have not responded with the same effort to address implementation of recommended practices on public restraints. ${ }^{188}$

Another previous working group, Antitrust Enforcement in Regulated Sectors, provided a general overview of how competition agencies work with sector agencies in the Interrelations between the Antitrust and Regulatory Authorities subgroup. ${ }^{189}$ Addressing how competition policy relates to

187 ICN, Future Plans of the Advocacy Working Group (Advocacy Working Group, 2002), available at http://www.internationalcompetitionnetwork.org/media/library/conference_1st_naples_2002/ future_plans.pdf.

188 J. William Rowley \& A. Neil Campbell, Implementation of the ICN's Recommended Merger Practices: A Work-in-(Early)-Progress, ANTITRUST SOURCE, July 2005, available at http://www.abanet. org/antitrust/at-source/05/07/Jul05-Rowley7=28f.pdf.

189 ICN, Competition Advocacy in Regulated Sectors: Examples of Success (Capacity Building \& Competition Policy Working Group, Apr. 2004), available at http://www.internationalcompetition network.org/media/library/conference 3rd seoul 2004/capacitybuild_sg4_seoul.pdf.; ICN, Competition Advocacy Review-Case Studies on Regulated Sectors (Competition Policy Implementation Working 
sector regulators has helped to lay out various effective ways for agencies to address overlapping concerns for the creation of a more efficient and competitive market. For example, case studies of the telecommunications and banking industries laid out specific recommended practices for agencies to adopt to limit anticompetitive restraints, including public restraints. ${ }^{190}$ Both reports provide a background of issues, a summary of current legal and economic approaches, and a proposed set of methods to improve the role and effectiveness of antitrust agencies in addressing issues of indirect immunities through sector regulation. Because these best practices are recent, what remains unknown is whether agencies actually follow ICN best practices in regulated industries. No follow-up work has been done to measure compliance and implementation of the recommended practices.

The weakness of the ICN specific to addressing antitrust public restraints is that it may not have United States and EU support. There has been no discussion at the ICN of immunities (such as export cartels), international trade/market access issues, or antidumping. No ICN work discusses how to overcome immunities directly. Moreover, most public restraints come about as a result of legislative failure. Agencies may not be so effective as to be able to police against existing public restraints, though they may be able to better affect the imposition of new public restraints. Thus, recommended practices can only go so far when it is not a market malfunction or a problem of coordination that causes the problem of public restraints. Rather, it seems to be the ability of governments to limit legislation that is both existing and proposed. Agencies can make progress in this area. However, this progress may be slow.

\section{Hard Law-The World Trade Organization}

The WTO is the major international organization that reduces government-created trade barriers among countries. Yet, there is a general reluctance on the part of many academics and policy makers to create binding international trade disciplines for antitrust law. ${ }^{191}$ The reluctance stems from issues that this Article addresses, such as a concern over a watered-down common standard, a trade analysis that is dissimilar to that of antitrust, and a belief that soft law solutions might be more effective than hard law solu-

Group, 2005), available at http:/www.internationalcompetitionnetwork.org/media/library/conference_ 4th_bonn_2005/Competition_Advocacy_Review.pdf.

190 See, e.g., ICN, REPORT OF THE ICN WORKING GROUP ON TELECOMMUNICATIONS SERVICES (May 3, 2006), available at http://www.internationalcompetitionnetwork.org/media/library/conference 5th_capetown_2006/Reportofthe_Telecoms_WorkingGroup.pdf; Biggar \& Heimler, supra note 120.

191 See, e.g., Paul B. Stephan, Global Governance, Antitrust, and the Limits of International Cooperation, 38 CORNELl INT'L L.J. 173, $175-76$ (2005); John O. McGinnis, The Political Economy of International Antitrust Harmonization, 45 WM. \& MARY L. REV. 549, $551-52$ (2003). 
tions. These reservations do not, however, focus on antitrust public restraints that come in the form of direct or indirect antitrust immunities. ${ }^{192}$

The purpose of the WTO is to serve as a pre-commitment mechanism. This pre-commitment function allows domestic governments to be constrained by international commitments, the better to counter domestic rentseeking interest groups. ${ }^{193}$ This pre-commitment mechanism reduces the opportunism that results from a global prisoner's dilemma. ${ }^{194}$ The WTO enables each country to make commitments with the knowledge that all other countries will be bound by the same commitments. Countries can also retaliate against actions by trading partners that harm a previously negotiated deal. ${ }^{195}$

To overcome the time-inconsistency problem (where government fails in its ability. to commit to future policies), countries may wish to bind themselves to an international commitment to uphold regulatory commitments. ${ }^{196}$ A binding international commitment locks in a domestic policy that might otherwise not survive a current government. ${ }^{197}$ To create such binding commitments, hard law uses delegation of authority from a country to a third party. A second element to hard law is that it has less ambiguity than soft law for the conduct required to abide by commitments made. ${ }^{198}$ Hard law enforces domestic compliance for countries through binding international adjudication. As such, hard law requires a level of centralized decision-making. Benefits from this centralization of binding international law include the creation of "increased consistency between local rules, internalization of externalities, [and] the creation of positive network effects due

192 To be sure, earlier efforts to use the WTO for antitrust problems covered public restraints generally. See, e.g., Draft Intemational Antitrust Code as a GATT-MTO-Plurilateral Trade Agreement (Int'1 Antitrust Code Working Group Proposed Draft, 1993), 64 Antitrust \& Trade Reg. Rep. (BNA) No. 1628 (Aug. 19, 1993) (Special Supp.).

193 Ernst-Ulrich Petersmann, Trade Policy as a Constitutional Problem: On Domestic Policy Functions of International Rules, 41 AUSSENWIRTSCHAFT 405 passim (1996).

194 The prisoner's dilemma is a stock game theory problem. See MARTIN SHUBIK, GAME THEORY IN THE SOCIAL SCIENCES: CONCEPTS AND SOLUTIONS 254 (1982).

195 Kyle Bagwell \& Robert W. Staiger, The Economics of the World Trading System 54-55 (2002).

196 Joseph Stiglitz, The Private Uses of Public Interests: Incentives and Institutions, $12 \mathrm{~J}$. ECON. PERSP. 3, 8-11 (1998). Some take a public choice view of this type of failure by the government. See, e.g., JAMES M. BUCHANAN, CONSTITUTIONAL ECONOMICS 35 (1991); Daron Acemoglu \& James A. Robinson, Inefficient Redistribution, 95 AM. POL. SCI. REV. 649, 649 (2001).

197 Lock-in may force countries to develop higher standards. Merit E. Janow, supra note 183, at 59; Andrew Moravcsik, The Origins of Human Rights Regimes: Democratic Delegation in Postwar Europe, 54 INT'L ORG. 217, 217-18 (2000).

198 Kenneth W. Abbott \& Duncan Snidal, Hard and Soft Law in International Governance, 54 INT'L ORG. 421, 427-28 (2000). 
to the use of common standards of interactions." 199 The enforcement of hard law rules allows for easier consistency than the soft law alternative because of the binding nature of hard law.

The WTO agreements bind countries the way other commitments (or contracts) do. ${ }^{200}$ Members limit their sovereignty to take advantage of the benefits of trade liberalization. A reduction in some domestic discretion to pursue parochial interests is part of the bargain to gain access to these trade benefits. The loss of sovereignty becomes part of a country's cost-benefit analysis. A country will give up some sovereignty if the benefits (such as increased trade and economic development) outweigh the costs.

International coordination at the WTO level may reduce costs of international problems. Increased cooperation allows for countries to create remedies jointly that will minimize the risk of inconsistent obligations. The strength of the WTO is that it may solve system-wide problems, because its rules can take into account interdependencies and externality effects in designing a common set of rules. ${ }^{201}$ International cooperation is necessary because domestic interests often neglect foreign consumers and their interests. ${ }^{202}$ The WTO may be the best way to protect these foreign interests.

Self restraint via binding international mechanisms protects governments from themselves. ${ }^{203}$ As the previous section on domestic institutional alternatives revealed, because domestic legislatures, sector regulators, and courts embed public restraints, overcoming such immunities domestically is difficult. The price of overcoming binding international commitments comes at significant reputational cost, because non-compliance makes other countries less likely to sign future agreements with a non-compliant country. Lock-in through binding international commitments provides political cover for agencies to foster procompetitive change, as governments can blame international commitments for change that would be unpopular domestically. ${ }^{204}$

199 Eric Brousseau \& Emmanuel Raynaud, The Economics of Private Institutions: An Introduction to the Dynamics of Institutional Frameworks and to the Analysis of Multilevel Multi-Type Governance 29 (July 2006), available at http://papers.ssrn.com/sol3/papers.cfm?abstract_id=920225.

200 Appellate Body Report, Japan-Taxes on Alcoholic Beverages, WT/DS10/AB/R, WT/DS1 1/AB/R, WT/DS8/AB/R (Oct. 24, 1996) ("The WTO Agreement is a treaty-the international equivalent of a contract."); Robert E. Hudec, Private Anticompetitive Behavior in World Markets: A WTO Perspective, 48 ANTITRUST Bull. 1045, 1049 (2003). But see Andrew T. Guzman, The Design of International Agreements, 16 EURO. J. INT'L L. 579, 583-85 (2005) (arguing that binding WTO commitments are different from contractual commitments).

201 This observation comes from an application of firm level behavior. See Bengt Holmstrom, The Firm as Subeconomy, 15 J.L. ECON. \& ORG. 74, 75-76 (1999).

202 McGinnis, supra note 191 , at 569.

203 Richard H. Thaler \& Cass R. Sunstein, Nudge: Improving Decisions about Health, WEALTH, AND HAPPINESS passim (2008) (discussing pre-commitment generally).

204 It is easier to ensure compliance when violations require administrative rather than legislative change. Bruce Wilson, Compliance by WTO Members with Adverse WTO Dispute Settlement Rulings: The Record to Date, 10 J. INT'L ECON. L. 397, 399 (2007). 
The fundamental problem that the WTO solves, as theoretical models explain, is insufficient market access. ${ }^{205}$ The WTO combats market access public restraints through non-discrimination. Non-discrimination requires that foreign firms be treated the same as domestic firms, and without discrimination from other trading partners as well. ${ }^{206}$ WTO commitments solidify a domestic policy in favor of non-discrimination by increasing the costs of non-compliance. ${ }^{207}$ Non-discrimination reduces opportunities for the erection of market access barriers and for countries to undertake a nationalist-driven trade policy. ${ }^{208}$

The WTO by its nature does not address private restraints by business. Rather, there must be some degree of government involvement in the discriminatory restraint for WTO jurisdiction to attach. ${ }^{209}$ By definition, the WTO therefore addresses public restraints of trade. WTO provisions are vague, however, so adjudication plays a significant role in determining the meaning of the text. This makes WTO adjudicators the primary institutional movers in the WTO. 210

Non-discrimination helps check domestic public choice impulses. It allows for foreign exporters to have more effective participation in domestic regulation that affects their competitiveness. ${ }^{211}$ Foreign exporters tend to be under-represented in domestic legislation. ${ }^{212}$ Since exclusion of foreign interests has aggregate effects on market competition and dynamic growth, international hard law commitments assist foreign firms to achieve equal regulatory footing with domestic firms.

The WTO has limitations in its ability to address public restraints. It can discipline discriminatory measures. However, if a measure applies the same way to domestic and foreign actors, there is no discrimination. Thus,

205 Jose E. Alvarez et al., It's a Question of Market Access, 96 AM. J. INT'L L. 56, 60 (2002); BAGWELL \& STAIGER, supra note 195, at 125-27.

206 Without companies on an equal footing, it is difficult for markets to function to allow for the benefits of competition to pass on to consumers. See J. Gregory Sidak \& Daniel F. Spulber, Deregulation and Managed Competition in Network Industries, 15 YALE J. REG. 117, 127 (1998).

207 Edward T. Swaine, Against Principled Antitrust, 43 VA. J. INT'L L. 959, 968 (2003).

208 Mariana Bode \& Oliver Budzinski, An Antitrust Primer for Federal Law Enforcement Personnel; Competing Ways Towards International Antitrust: The WTO Versus the ICN, in ANTITRUST POLICY ISSUES 85 (Patrick Moriati ed., 2006).

209 Rex J. Zedalis, When do the Activities of Private Parties Trigger WTO Rules?, 10 J. INT'L ECON. L. 335, 335-37 (2007).

210 Gregory Shaffer, Recognizing Public Goods in WTO Dispute Settlement: Who Participates? Who Decides?, 7 J. INT'L ECON. L. 459, 470 (2004).

211 Miguel Poiares Maduro, Europe and the Constitution: What if This is as Good as it Gets?, in European Constitutionalism Beyond the State 74, 85 (J.H.H. Weiler \& Marlene Wind eds., 2003); McGinnis, supra note 191, at 552

212 Maduro, supra note 211, at 93 ("Most instances of discrimination against (or underrepresentation of foreign nationals in national political processes are, at the same time, instances of capture of the national political process by a national interest group against the interests of a dormant national majority."). 
this is not an area in which the policy of non-discrimination will have an effect. The WTO cannot ban inefficient government measures that apply equally to domestic and foreign firms. Diagram B explains these potential overlaps:

\section{DIAGRAM B. INTERSECTION OF ANTITRUST AND INTERNATIONAL TRADE}

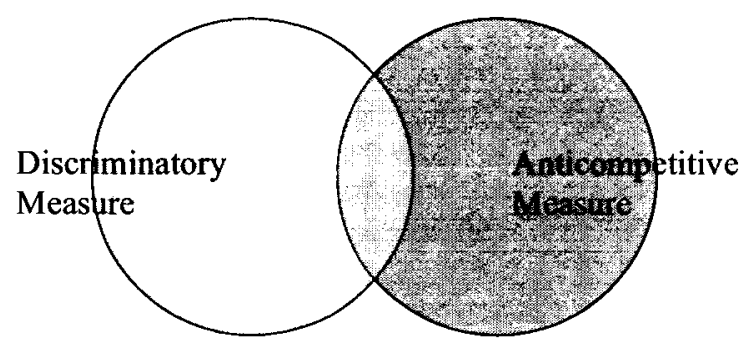

In Diagram B above, the WTO can address only the shaded behavior that is both anticompetitive and that discriminates between foreign and domestic actors. As this diagram illustrates, non-discrimination does not preclude anticompetitive behavior from antitrust. Rather, to avoid sanction, the regulation must apply equally to domestic and foreign actors. ${ }^{213}$ This allows countries to maintain policy choices (such as immunities) at the domestic level-so long as the immunities impact both domestic and foreign firms. Nevertheless, non-discrimination removes some anticompetitive antitrust immunities. And its more active use could reduce the ability of countries to discriminatorily apply their antitrust laws to create national champions. Non-discrimination could be fairly broad if de facto discrimination is included. A regulation that appears to treat foreign and domestic companies equally could have a disparate impact on foreigners.

213 WTO, Core Principles, Including Transparency, Non-Discrimination and Procedural Fairness: Background Note by the Secretariat 9 2-5, WT/WGTCP/W/209 (Working Group on the Interaction between Trade and Competition Policy, Sept. 19, 2002), available at http://docsonline.wto.org/imrd/ directdoc.Asp?DDFDocuments/t/WT/WGTCP/W209.doc. 
WTO jurisdiction attaches even when there may be domestic institutional responses to solve these problems. In some cases, the WTO response may be less effective than the domestic one and would allow global regulators to second guess domestic regulations. Additionally, there are limits to the WTO's adjudicatory capacity to address issues in which there may be an overlap between discriminatory and anticompetitive measures, as the subsequent case study on Canada-Measures Relating to Exports of Wheat and Treatment of Imported Grain ("Canada Wheat") 214 will illustrate.

The WTO has some capacity to address externality-creating public restraints. For example, under the WTO Subsidies and Countervailing Measures Agreement, WTO commitments limit export subsidies to those countries that specify on their list of commitments. ${ }^{215}$ WTO rulings against both the U.S. and the EU in subsidies cases demonstrate that these commitments apply even to the most powerful members of the WTO. ${ }^{216}$ Whereas domestic institutions lack the incentives to tackle externalities-causing problems, the WTO has the incentive to reduce trade-distorting externalities at the country level more effectively than soft law because government-togovernment level negotiations reduce trade-distorting effects. ${ }^{217}$

There are limitations to the WTO's ability to address public restraints. ${ }^{218}$ An implicit assumption against inclusion of a role in antitrust regulation for the WTO is that somehow antitrust is "pure," and based on

214 Appellate Body Report, Canada-Measures Relating to Exports of Wheat and Treatment of Imported Grain, WT/DS276/R (Apr. 6, 2004); WTO Appellate Body Report, Canada-Measures Relating to Exports of Wheat and Treatment of Imported Grain, AB-2004-3 (2004).

215 Agreement on Subsidies and Countervailing Measures, Apr. 15, 1994, Marrakesh Agreement Establishing the World Trade Organization, Annex 1(A), Legal Instruments-Results of the Uruguay Round, 33 I.L.M. 1125, 1154 (1994).

216 Appellate Body Report, United States -Subsidies on Upland Cotton, AB-2004-5 (2004); Appellate Body Report, European Communities-Export Subsidies on Sugar, AB-2005-2 (2005).

217 A WTO solution on spillovers is somewhat analogous to antitrust scholarship on the impact of the U.S. state action exemption. Inman and Rubinfeld suggest a two-part approach to address the spillover problem in state action jurisprudence that can be applied internationally as a way to determine the feasibility of international intervention for public restraints. First, a court would decide the economic impact of an anticompetitive spillover. Second, the court would examine if the interests of foreign consumers were included in the deliberation of the state act. If both inquiries are affirmed then the state regulation fails their monopoly spillover test. If so, a review of the regulation is appropriate. Robert $\mathbf{P}$. Inman \& Daniel L. Rubinfeld, Making Sense of the Antitrust State-Action Doctrine: Balancing Political Participation and Economic Efficiency in Regulatory Federalism, 75 TEX. L. REV. 1203, 1276 (1997). Those U.S. practitioners and policymakers that oppose a role for international binding commitments in antitrust may not import the thinking of their own experience of domestic public restraints that cause negative externalities.

218 This is not the first article to address the WTO's capacity to address public restraints. Much of the discussion on the WTO in an antitrust context addresses public restraints. However, little of this academic and policy discussion focuses on antitrust immunities and no previous work utilizes comparative institutional analysis to enrich this discussion. Indeed, as the capacities of the WTO have shifted vis-à-vis other institutional alternatives since WTO discussions began on competition policy in 1996, the desirability of the role of the WTO requires a comparative institutional analysis. 
efficiency concerns, and trade is "impure," as trade concessions are the result of trade-offs among producer interests. ${ }^{219}$ However, antitrust regulation domestically is also a result of trade-offs as to what sort of policies may be undertaken (and what may be immune) and the scope of prosecutorial discretion that an agency may have. ${ }^{220}$

\section{INSTITUTIONAL FAILINGS IN COMPETITION POLICY}

\section{A. WTO Adjudication: A Case Study}

Nearly sixty provisions within the WTO address various competition issues. ${ }^{221}$ Some of this regulation of competition is implicit in the text. ${ }^{22}$ Yet, explicit provisions for antitrust regulation may be unnecessary because of implicit existing coverage in WTO commitments on goods, services, and other provisions. ${ }^{223}$ A critical question is how effective has the WTO been in addressing an antitrust-style analysis and in melding trade rules with antitrust concepts based on industrial organization economics. In some situations, a WTO policy of non-discrimination may solve antitrust problems. ${ }^{224}$ However, as Diagram B above illustrates, there may be cases in which a market access issue is not a function of anticompetitive conduct (i.e., not an antitrust issue). The ability of the WTO to distinguish between such situations tests the feasibility of the WTO to remedy potential anticompetitive public restraints that implicate antitrust-specific issues.

Results of recent WTO case law are not promising. Thus far, there have been few WTO dispute settlement adjudications that address antitrust regulation directly or indirectly. ${ }^{225}$ The WTO dispute system, as currently

219 Daniel K. Tarullo, Norms and Institutions in Global Competition Policy, 94 AM. J. INT'L L. 478, 489-94 (2000).

220 Fred S. McChesney, Economics Versus Politics in Antitrust, 23 HARV. J.L. \& PUB. POL'Y 133 (1999).

221 Jose E. Alvarez \& John H. Jackson, Afterword: The Linkage Problem-Comments on Five Texts, 96 AM. J. INT'L L., 118, 124 (1996).

222 Emst-Ulrich Petersmann, WTO Core Principles and Trade/Competition Roundtable, in INTERNATIONAL ANTITRUST LAW \& POLICY 2003, supra note 63, at 669; Alvarez \& Jackson, supra note 221, at 124 ("In short, as to competition policy being dealt with by the WTO Agreements, there is already a substantial position for the WTO (those who resist are too late!).").

223 It is quite possible that similar types of arguments could be made about other specialized areas of law that the WTO implicates such as tax or investments. An analysis of the appropriate institution to address those and other specialized areas is beyond the scope of this article.

224 BAGWELL \& STAIGER, supra note 195, at 162.

225 See, e.g., Panel Report, Japan-Measures Affecting Consumer Photographic Film and Paper, WT/DSAA/R (Mar. 31, 1998); Panel Report, Mexico-Measures Affecting Telecommunications Services, WT/DS204/R (Apr. 2, 2004); Appellate Body Report, United States-Anti-Dumping Act of 1916, WT/DS136/AB/R \& WT/DS162/AB/R (Aug. 28, 2000); Appellate Body Report, Canada-Measures 
conceived, has serious shortcomings with regard to its ability to handle competition and competition-related cases. And preliminary results indicate that the WTO may lack the competency to handle economically sophisticated cases that are fact-intensive.

To illustrate the current capacity of WTO adjudication in this area, this Article examines one relatively recent case, Canada Wheat, as a case study with which to draw broader conclusions about the current form of WTO adjudication. It illustrates that WTO jurisprudence is formalistic and lacks the economic sophistication of antitrust decisions by generalized courts in more developed antitrust jurisdictions. ${ }^{226}$

Agriculture is a sector of the economy particularly prone to government distortions. How these distortions affect competition is a difficult question, given the various public restraints that combine with potential private restraints. In Canada Wheat, the U.S. alleged that the Canada Wheat Board ("CWB") used its legal and regulatory structure to engage in business conduct that distorted markets in Canada and abroad. ${ }^{227}$ Upon appeal, the more limited competition-related claim was that the CWB used its anticompetitive advantages in third country markets to engage in predatory pricing. ${ }^{228}$ The U.S. alleged that the CWB could undertake such action, which would be unprofitable for ordinary businesses, because it was a State Trading Enterprise ("STE").

As an STE, the CWB enjoyed certain government privileges that private firms lacked, which, in turn, affected the overall market and the international competitiveness of domestic firms. Though the United States couched many of its claims about the CWB within a competition framework, it did not undertake a detailed, fact-intensive inquiry of the effects of the CWB within an antitrust context. Put differently, the United States did not present evidence sufficient to satisfy an antitrust claim. An antitrust analysis in the case could have been used to prove or disprove larger questions of "competitive" distortions.

Under WTO jurisprudence, STEs have very few constraints on their behavior. An STE, under GATT Article XVII:1(a), must act in a nondiscriminatory manner and, under GATT Article XVII:1(b), must operate

Relating to Exports of Wheat and Treatment of Imported Grain, WT/DS276/R, AB-2004-3 (Aug. 30, 2004).

226 See J. Gregory Sidak \& Hal J. Singer, Uberregulation Without Economics: The World Trade Organization's Decision in the U.S.-Mexico Arbitration on Telecommunications Services, 57 FED. COMM. L.J. 1, 3-4 (2004); Damien J. Neven \& Petros C. Mavroidis, El Mess in TELMEX: A Comment on Mexico-Measures Affecting Telecommunications Services, 5 WORLD TRADE REV. 271, 272 (2006).

227 Panel Reports, Canada-Measures Relating to Exports of Wheat and Treatment of Imported Grain, IT 6.12-.28, WT/DS276/R (Apr. 6, 2004).

228 Appellate Body Report, Canada-Measures Relating to Exports of Wheat and Treatment of Imported Grain, I 39, WT/DS276/R, AB-2004-3 (Aug. 30, 2004) (The U.S. claimed "that the CWB's legal structure and mandate, together with the privileges enjoyed by the CWB, create[d] an incentive for the CWB to make sales which are not solely in accordance with commercial considerations."). 
using commercial considerations. ${ }^{229}$ Canada Wheat illustrates the limits of the current WTO treatment of competition issues. The case offers an example of the current gap in WTO thinking and supports a claim that current WTO rules do not pose a credible constraint on the operations of STEs. ${ }^{230}$

In Canada Wheat, the U.S. claimed that (1) the CWB export regime was inconsistent with obligations under GATT Article XVII:1; and (2) certain measures relating to Canada's bulk grain handling system and to the transportation of grain by rail in Canada were inconsistent with Canada's obligations under GATT Article III: $4^{231}$ and Article 2 of the Agreement on Trade-Related Investment Measures. ${ }^{232}$ On appeal, the case addressed only the Article XVII: 1 complaint.

In its Article XVII:1 complaint, the U.S. enumerated the advantages that the CWB enjoyed because of its state ownership. These preferences included

\begin{abstract}
the CWB's monopoly right to purchase Western Canadian grain for domestic human consumption and export, the approval and guarantees of initial payments to farmers by the Canadian government, and the reimbursement by the Canadian Parliament of losses sustained by the CWB ... [ [and] the Canadian government's guarantee of all CWB borrowings. This guarantee allows the CWB to borrow at more favourable rates and then loan funds at a higher rate, thereby generating interest income. This additional revenue . . . is a key element of the CWB's legal framework that gives the CWB increased pricing flexibility and, in turn, creates incentives to make sales in a non-commercial manner. ${ }^{233}$
\end{abstract}

These are all preferences that private companies competing against the CWB lack. The U.S. argued that the use of government-created privileges for the CWB itself meant that the CWB did not operate under commercial considerations. According to the U.S., these preferences suggested that there were no disciplines against government behavior. Competing against the government is not the same as competing against private firms because

229 General Agreement on Tariffs and Trade, art. XVII:1 (b), Oct. 30, 1947, 61 Stat. A-11, 55 U.N. T.S. 194 [hereinafter GATT].

230 MiChael J. TREBILCOCK \& Robert Howse, THE Regulation of InTERNATIONAL Trade $347-48$ (3d ed. 2005).

231 GATT art. III I 4 (requiring that imported products "shall be accorded treatment no less favourable than that accorded to like products of national origin in respect of all laws, regulations and requirements affecting their internal sale, offering for sale, purchase, transportation, distribution or use").

232 Agreement on Trade-Related Investment Measures, Apr. 15, 1994, Marrakesh Agreement Establishing the World Trade Organization, Annex 1A, 1868 U.N.T.S. 186 [hereinafter TRIMs]. Under Article II of TRIMs (national treatment), the United States relied upon language in Paragraph 1(a) of the Annex to the TRIMs Agreement. The national treatment obligations include domestic law or administrative rulings that provide advantages to domestic firms through "the purchase or use by an enterprise of products of domestic origin or from any domestic source, whether specified in terms of particular products, in terms of volume or value of products, or in terms of a proportion of volume or value of its local production." TRIMs, supra, at Annex I 1(a).

233 Appellate Body Report, Canada-Measures Relating to Exports of Wheat and Treatment of Imported Grain, \38, WT/DS276/R, AB-2004-3 (Aug. 30, 2004). 
of the special privileges provided that might allow a firm to artificially lower its cost of doing business or to focus on revenue maximization over profit maximization. ${ }^{234}$

The Appellate Body ruled in favor of the CWB. More importantly, and critical to understanding the limitations of the WTO in addressing competition issues, the Appellate Body explicitly rejected an antitrust law analysis as inappropriate to a discussion of STE behavior and what might be meant by STE "commercial considerations." tion under Article XVII:1 must be assessed by means of a market-based analysis based on "commercial considerations." The Appellate Body then suggested that if the CWB used the privileges and advantages that it enjoyed, this did not disadvantage private enterprises. ${ }^{236}$ If the privileges in question in fact provided the CWB with advantages that a private firm lacked based on various implicit subsidies and state aid, the Appellate Body analysis did not take into account that the STE privileges may have significantly distorted the market.

The Appellate Body reasoned that limitations inherent in Article XVII: 1 allowed for some distortions. Under the Appellate Body's reasoning, these distortions would seem to include the ability to price discriminate for anticompetitive purposes. ${ }^{237}$ It would also include price discrimination for the purpose of predatory pricing. ${ }^{238}$ The U.S. framed the case as one of raising rivals' costs or predation based on the effect of the various privileges that the CWB received. ${ }^{239}$ The U.S. claimed a firm that operates under commercial considerations must "sell at prices that, at a minimum, would equal the replacement value of a good." ${ }^{240}$ This is shorthand for the need of a commercial firm to cover its marginal costs. However, the panel did not

234 David E.M. Sappington \& J. Gregory Sidak, Incentives for Anticompetitive Behavior by Public Enterprises, 22 REV. INDUS. ORG. 183, 183-84 (2003).

235 Appellate Body Report, Canada-Measures Relating to Exports of Wheat and Treatment of Imported Grain, I 145, WT/DS276/R, AB-2004-3 (Aug. 30, 2004).

236 Id. ๆ甲 148-49.

237 Id. .ा $96-97$.

238 Id. ๆๆ 28-29.

239 However, the record did not contain data suggesting which firms had their costs raised on the global wheat export market nor which firms had suffered from claims of "predation." On predatory pricing, see Phillip Areeda \& Donald F. Turner, Predatory Pricing and Related Practices Under Section 2 of the Sherman Act, 88 HARv. L. REV. 697, 697 (1975); Einer Elhauge, Why Above-Cost Price Cuts To Drive Out Entrants Are Not Predatory-and the Implications for Defining Costs and Market Power 112 YAle L.J. 681, 711-14 (2003); Daniel A. Crane, The Paradox of Predatory Pricing, 91 CoRnell L. Rev. 1 , 1 (2005); Jonathan B. Baker, Predatory Pricing After Brooke Group: An Economic Perspective, 62 ANTITRUST L.J. 585, 585 (1994); Aaron S. Edlin, Stopping Above-Cost Predatory Pricing, 111 YALE L.J. 941,941 (2002). On raising rivals costs, see Thomas G. Krattenmaker \& Steven Salop, Anticompetitive Exclusion: Raising Rivals' Costs to Achieve Power Over Price, 96 YALE L.J. 209, 230 (1986); Steven C. Salop \& David T. Scheffman, Raising Rivals' Costs, 73 AM. ECON. REV. 267, 267 (1983).

240 Appellate Body Report, Canada-Measures Relating to Exports of Wheat and Treatment of Imported Grain, \29, WT/DS276/R , AB-2004-3 (Aug. 30, 2004). 
provide an economics-based approach to support such an analysis. This lack of analysis in the trade context contrasts with the antitrust analysis of such claims.

At no point in either the panel or Appellate Body decisions was there a discussion of the relevant market, a basic inquiry in antitrust law. Increasingly, scholars suggest that quantity and product homogeneity are not appropriate measures for certain commodity markets. ${ }^{241}$ This includes wheat markets, where there are three potentially distinct world markets for wheat: durum; high quality wheat; and low-grade, animal feed-quality wheat. ${ }^{242}$ In Canada Wheat, there was no discussion of an in-depth analysis of geographic markets and product markets for each type of grain. It may be that "global" markets are not so global because of transportation costs or tariff barriers. $^{243}$

Once the market has been defined, then a competition analysis would examine whether a business has market power and has abused such power. As one leading agricultural economist notes, "[t]ypically, where market power is believed to exist in commodity markets, state trading institutions or other trade interventions exist and are required for that power to be exercised." 244 It is helpful to distinguish between two meanings of market power-antitrust market power and non-antitrust market power (although economists tend to use the two meanings interchangeably, this leads to some confusion). ${ }^{245}$ In the first meaning, market power is antitrust market power. In antitrust market power, there is an ability to maintain price above the competitive level or to exclude competitors from the market. In nonantitrust market power, a firm can set prices above marginal cost. However, it cannot sustain this above the competitive price. For example, a store that has market power but lacks antitrust market power and charges too high a price for coffee will find that consumers will flock to other nearby coffee shops or substitute other products for coffee. Carlton and Perloff describe antitrust market power as "monopoly power" and draw the distinction as follows: "Prices may exceed marginal cost even though profits are not above competitive levels. For example, if there are large enough fixed

241 Colin A. Carter \& Donald MacLaren, Price or Quantity Competition? Oligopolistic Structures in International Commodity Markets, 5 REV. INT'L ECON. 373, 373-74 (1997); Troy G. Schmitz \& Richard Gray, State Trading Enterprises and Revenue Gains from Market Power: The Case of Barley Marketing and the Canadian Wheat Board, 25 J. AGRIC. RESOURCE ECON. 596, 610 (2000).

242 W.H. Furtan, D.F. Kraft \& EW. Tyrchniewicz, Can the Canadian Wheat Board Extract Monopoly Rents? The Case of the Spring Wheat Market, 6 INT'L J. ECON. BUS. 417, 417-18 (1999).

243 See Richard J. Sexton \& Mingxia Zhang, An Assessment of the Impact of Food Industry Market Power on U.S. Consumers, 17 AGRIBUSINESS 59, 59-60 (2001) (examining the impact on consumers in the U.S. caused by market power at the manufacturer or retailer stage of the food production chain).

244 Philip C. Abbott, Competition Policy and Agricultural Trade 6-7 (OECD Workshop on Emerging Trade Issues in Agriculture, COM/AGR/CA/TD/TC/WS(98)106, 1998).

245 Dennis W. Carlton \& JefFrey M. PERloff, Modern industrial Organization 92 (3d ed. 2000). 
costs, profits may be zero even if price exceeds marginal cost." ${ }^{246}$ One could usefully distinguish the two terms by using "monopoly power" to describe a market in which price exceeds marginal cost and profits are above competitive levels, and using "market power" for markets in which price exceeds marginal costs, but profits are not above competitive levels. Academics and policy makers who make claims against STEs generally, and the CWB specifically, often discuss "market power." ${ }^{247}$ Using the Carlton and Perloff terminology, these claims are of market power rather than monopoly power. It is possible that with global markets and differentiated products, the exclusion of STEs from antitrust may allow STEs to limit output and/or raise prices because of their monopoly power. If antitrust law could reach this behavior, however, it would limit the ability of STEs to exercise monopoly power.

The STE status of the CWB should have played into the competition analysis in Canada Wheat. There are two types of STEs-import and export STEs. The CWB is both an import and export STE. Export STEs only have an anticompetitive spillover effect when they are large enough to possess international monopoly power for a particular good. Thus, only large exporting countries potentially may have monopoly power. Small country export STEs lack such monopoly power. Wheat is one such product, over which large-country STEs may have monopoly power globally in the export market. ${ }^{248}$ The structure of STEs also impacts their ability to exercise market power internationally. International agriculture markets tend to be imperfect competition/oligopolistic markets because of high levels of concentration among sellers. ${ }^{249}$ Because many international food markets are oligopolistic in structure, opportunities exist for firms to capture rents from these markets. ${ }^{250}$

The problem with the CWB case is that the United States did not offer, nor did the case record show, any evidence of CWB export monopoly power supporting an exclusion claim. There was no indication that globally consumers were hurt from the CWB's pricing decisions. Indeed, quite the opposite: consumers benefited from lower prices for wheat. There was no support to the claim that the CWB somehow engaged in predation. Why would the CWB want to engage in such predation? If because of its STE status (and its immunity from antitrust) it sought revenue maximization

\footnotetext{
246 Id.

247 Appellate Body Report, Canada-Measures Relating to Exports of Wheat and Treatment of Imported Grain, 9171 , 147 WT/DS276/R, AB-2004-3 (Aug. 30, 2004).

248 Daniel H. Pick \& Timothy A. Park, The Competitive Structure of U.S. Agricultural Exports, 73 AM. J. AGRIC. ECON. 133, 133 (1991).

249 Jeffrey J. Reimer \& Kyle Stiegert, Imperfect Competition and Strategic Trade Theory: Evidence for International Food and Agricultural Markets, 4 J. AGRIC. \& FOOD INDUS. ORG. 1, 6-7 (2006) (providing a literature review of previous studies).

250 Stephen F. Hamilton \& Kyle W. Stiegert, An Empirical Test of the Rent-Shifting Hypothesis: The Case of State Trading Enterprises, 58 J. INT'L ECON. 135, 155 (2002).
} 
rather than profit maximization (which is why private firms are in business), the CWB could have driven competitors out of business with predatory prices without the need for recoupment. If, however, the STE benefited from not having to recoup profits because the Canadian government implicitly subsidized it, a traditional antitrust analysis of predation based on private business behavior might not catch such behavior, since it would assume that private actors would undertake behavior only if it was possible to recoup the below-cost pricing. ${ }^{251}$

An import STE can impact international trade through market access barriers, no matter what the size of the country, because it can limit access to that particular country's market. For an import STE to have an anticompetitive effect, it must have a number of attributes. The STE must be able to set up barriers to entry and exit. There must be no close product substitutes. The STE must be granted certain exclusive rights and be exempted from antitrust regulation. Because of the antitrust exemption, an import STE may be granted privileges that confer monopoly power to it. For example, an import STE may be the only seller of a product within a domestic market, giving it monopoly power with regard to price. If an STE is both a stateowned enterprise and a monopolist, it may be able to use a strategy of predation to keep out foreign entrants. ${ }^{252}$ The STE may also be able to boycott distributors who might otherwise deal with foreign producers who seek access to the market. In a global context, an STE may have enough buyer power to call the shots in the world market for certain goods. However, in Canada Wheat, such a claim seems farfetched. To successfully undertake predation, there first needs to be proof that an entity such as the CWB has monopoly power. The WTO Appellate Body decision did not address this issue.

The U.S. claim (never proved in the Canada Wheat case) was that the CWB could cross-subsidize from the import-to-export markets. ${ }^{253} \mathrm{~A}$ review of the academic literature on the CWB exports allows for a review of the validity of the predation claim. Any commercial actor may price discrimi-

251 Brooke Group Ltd. v. Brown \& Williamson Tobacco Corp., 509 U.S. 209, 224 (1993) ("[I]t is the means by which a predator profits from predation."); Sokol, Comparative Corporate Governance, supra note 17.

252 David E.M. Sappington \& J. Gregory Sidak, Are Public Enterprises the Only Credible Predators?, 67 U. CHI. L. REV. 271, 271 (2000); David E.M. Sappington \& J. Gregory Sidak, Competition Law for State-Owned Enterprises, 71 ANTITRUST L.J . 479, 479-80 (2003).

253 Colin A. Carter, R.M.A. Loyns \& Derek Berwald, Domestic Costs of Statutory Marketing Authorities: The Case of the Canadian Wheat Board, 80 AM. J. AGRIC. ECON. 313, 323 (1998) (arguing that the CWB regime may come with domestic costs, even to producers, as the CWB may be inefficient in its goal); Julian M. Alston et al., Third-Country Effects and Second-Best Grain Trade Policies: Export Subsidies and Bilateral Liberalization, 79 AM. J. AGRIC. ECON. 1300, 1300 (1997) (suggesting that both the U.S. and Canada would benefit from the elimination of trade distorting policies). 
nate across markets based on what those markets are willing to bear. ${ }^{254}$ The evidence before the WTO did not suggest otherwise. The CWB did price discriminate. ${ }^{255}$ The CWB achieved price discrimination through a policy of increasing sales to price-inelastic markets and decreasing sales to elastic markets. ${ }^{256}$ An ability to undertake price discrimination is not unique to STEs such as the CWB. Private firms can and do price discriminate. In many cases, price discrimination may have procompetitive effects, such as increased efficiency. ${ }^{257}$

A number of jurisdictions use price-cost tests to measure predation, such as average variable cost as a proxy for marginal cost, average avoidable cost, average total cost, or long run average incremental cost. Each test has its advantages and disadvantages. None of these tests adequately account for the unique situation of state owned enterprises, or "SOEs," of which STEs are a subset, because in practice these tests assume that costs are not distorted by government privileges or soft budget constraints.

A number of jurisdictions use a recoupment test to determine whether or not there was predation. There was no such discussion in the panel or Appellate Body decisions as to the appropriate test (or indeed any test) to determine how to measure if the CWB operated under commercial considerations. Had such an analysis been undertaken, the panel would have confronted unique issues presented by SOE anticompetitive conduct. That is, a firm that does not act commercially has the ability to undertake strategies like predatory pricing or raising rivals' costs, in which it can "use its special privileges to gain market share through long-run price under-cutting."258 Commercial actors are ones that are interested in financial return in which market forces and cost constraints limit their ability to act. ${ }^{259}$ When actors

254 PHILIP E. AREEDA \& HERBERT HOVENKAMP, ANTITRUST LAW: AN ANALYSIS OF ANTITRUST PRINCIPLES AND THEIR APPLICATION 1721 (e) (1995).

255 Appellate Body Report, Canada-Measures Relating to Exports of Wheat and Treatment of Imported Grain, I 121, WT/DS276/R, AB-2004-3 (Aug. 30, 2004).

256 Harvey Brooks \& Troy G. Schmitz, Price Discrimination in the International Grain Trade: The Case of Canadian Wheat Board Feed Barley Exports, 15 AGRIBUSINESS 313, 314 (1999). But see Colin A. Carter \& R.M.A. Lyons, The Canadian Wheat Board: Its Role in North American State Trading (Institute of Int'l Studies Working Paper, 1998), available at http://aic.ucdavis.edu/oa/stecwb.pdf (arguing that the CWB does not pursue a policy of strategic trade behavior via price discrimination).

257 Leegin Creative Leather Prods., Inc. v. PSKS, Inc., 551 U.S. 877, 887-89 (2007) (“"E]conomics literature is replete with procompetitive justifications for a manufacturer's use of resale price maintenance."). See, e.g., William J. BAUMOL, REgulation Misled By MisRead Theory: PERfect Competition and COMPETITION-IMPOSED Price Discrimination 2 (2006); ABA SECTION OF ANTITRUST LAW, ANTITRUST LAW AND ECONOMICS OF PRODUCT DISTRIBUTION 76 (2006) ("[T]he bulk of the economic literature on [resale price maintenance] . . . suggests that [it] is more likely to be used to enhance efficiency than for anticompetitive purposes."); HERBERT HOVENKAMP, THE ANTITRUST ENTERPRISE: PRINCIPLE AND EXECUTION 184-91 (2005).

258 Appellate Body Report, Canada-Measures Relating to Exports of Wheat and Treatment of Imported Grain, \29, WT/DS276/R, AB-2004-3 (Aug. 30, 2004).

259 Id. \ 138. 
do not face these constraints, they are not commercial in nature (such as many SOEs).

The CWB domestic policies involve rent transfers among farmers with a system that provides income stability. It is necessary to have continuity of participation in the CWB, or the system is ruined. Thus, there is a quid pro quo inherent in the price pooling system. Where consumers benefit from lower prices in export markets, there is no antitrust problem for consumers in the export markets. Instead, the only consumers that lose out are those in the Canadian domestic market, who are taxed to pay for the implicit export subsidies and who pay higher prices domestically for cartelized wheat.

Because the antitrust exemption permits the CWB to cartelize, the CWB can price pool. ${ }^{260}$ The practice of price pooling minimizes the price and income risk to producers. This allows the CWB to have greater flexibility than private exporters when pricing products in the world market. ${ }^{261} \mathrm{~A}$ private firm such as Cargill could buy and have deferred payments and price pool. The difference is that a private firm cannot pursue this strategy as effectively as the CWB because of the implicit preferences that the $\mathrm{Ca}$ nadian government gives to the CWB.

Even if the United States had been able to show proof of antitrust anticompetitive harm, however, the WTO adjudicators seemed unable to understand the economics concepts as to the potential differing incentives of SOEs relative to private firms. The panel had stated that "the CWB might, due to the privileges it enjoys, sell wheat at lower prices than 'commercial actors' could offer." 262 Nevertheless, in its review of the case the Appellate Body did not believe that such selling at distorted costs constituted noncommercial sales. ${ }^{263}$ This recognition suggests that even if the CWB was successful in raising rivals' costs, this would not qualify as "noncommercial sales" (i.e., sales that would violate the applicable GATT articles). But if the CWB were no different from a private firm like Cargill, it would not be able to sustain such pricing because it would need to recoup its below-marginal cost losses. Theoretically, this claim about predation

260 Jana Hranaiova, Harry de Gorter \& Merlinda Ingco, Perspectives on Agricultural Export State Trading Enterprises in the WTO Trade Negotiations (Agriculture and Rural Dev. Working Paper No. 31925, 2002), available at http://www.ppl.nl/bibliographies/wto/files/3104.pdf (analyzing the effects of an export subsidy due to price pooling); Steve McCorriston \& Donald MacLaren, State Trading, the WTO and GATT Article XVII, 25 WORLD ECON. 107, 124 (2002).

261 See Michael D. Wilcox, Jr. \& Philip C. Abbott, Market Power and Structural Adjustment: The Case of West African Cocoa Market Liberalization (Working Paper Presented at the Am. Agricultural Econ. Assoc. Annual Meeting, 2004) available at http://ageconsearch.umn.edu/bitstream/20084/1/ sp04wi05.pdf (finding that in African countries in which there are few competition agencies, liberalized agriculture markets have created opportunities for firms to exert market power via vertical integration against small farmers).

262 Appellate Body Report, Canada-Measures Relating to Exports of Wheat and Treatment of Imported Grain, f 170, WT/DS276/R, AB-2004-3 (Aug. 30, 2004).

263 Id. 
could be true. However, predation claims are difficult to prove in an antitrust context. ${ }^{264}$ Moreover, the United States did not make a showing of such claims in the record at the panel level. And, although the Appellate Body suggested that it was concerned with such an analysis, neither it nor the lower level panel did so in its decision. ${ }^{265}$

The Appellate Body found that the panel had taken into consideration that the CWB enjoyed privileges over that of private traders and that even with these privileges, the CWB could act with commercial considerations. ${ }^{266}$ This assumes that international private companies may exercise monopoly power and that STEs are no different. However, private companies do not operate with the same special privileges, even if they may undertake the same type of behavior. Additionally, anticompetitive conduct by private traders can be remedied by antitrust regulation. In contrast, the CWB is immune from Canadian antitrust regulation.

The Appellate Body did not accept that these privileges allowed the CWB to act outside commercial considerations. Canada argued that the GATT lacked provisions prohibiting anticompetitive conduct, so that the privileges could be used so long as an STE behaved as "a rational market actor." ${ }^{267}$ If one assumes that a rational market actor would use anticompetitive behavior to raise rivals' costs or undertake a predation strategy because of its privileges, then any STE could behave as a rational market actor. Such reasoning provides carte blanche justification for nearly any type of anticompetitive behavior. In the case of the CWB, neither the evidence in the case nor the underlying secondary evidence suggested that the CWB has monopoly power. Without such power, the distortions in question, based on the private actor versus STE distinction, are irrelevant because the CWB lacks the monopoly power with which to abuse its position. Moreover, even if the CWB had such power, any potential entrant may only be one growing season away from entering the market for international grain to eliminate this monopoly power. Thus, the WTO Appellate Body probably reached the correct result. However, the reasoning by which the panel and Appellate Body reached this result is highly problematic. But, given a better set of facts, the lack of a distinction that the WTO draws between commercial and non-commercial actors could lead to perverse results that would allow STEs

264 See, e.g., Matsushita Elec. Indus. Co. v. Zenith Radio Corp., 475 U.S. 574, 585-86 (1986); Brooke Group Ltd. v. Brown \& Williamson Tobacco Corp., 509 U.S. 209, 210 (1993); United States v. AMR Corp., 335 F.3d 1109, 1115 (10th Cir. 2003).

265 Appellate Body Report, Canada-Measures Relating to Exports of Wheat and Treatment of Imported Grain, 1 144, WT/DS276/R, AB-2004-3 (Aug. 30, 2004) ("[O]nly such an analysis will reveal the type and range of considerations properly considered 'commercial' as regards purchases and sales made in those markets, as well as how those considerations influence the actions of participants in the market[s].").

266 Id. $\$ 170$.

267 Id. $\ 47$. 
to exploit a monopoly position due to antitrust public restraints without effective WTO redress.

\section{B. A Proposal for Reform}

The current state of underdeveloped mechanisms to remedy antitrust public restraints through domestic or soft law institutions may require an institutional choice of centralization and hard law. A hard law solution could raise the bar globally and prevent certain forms of anticompetitive public restraints. ${ }^{268}$ The WTO is the preferred institution, but its current powers are not well-adapted to address public restraints. Consequently, an effective WTO solution entails a broadening of the WTO's powers to more adequately address antitrust-related public restraints, while remedying the existing WTO adjudicatory malfunctions on competition issues.

Public restraints may be the rare situation in which a gap in enforcement may justify a hard law solution and increased centralization vis-à-vis other institutional alternatives. This would require an understanding of when it is appropriate and relevant for international institutions to secondguess domestic ones. Coverage of public restraints at the WTO level allows for a new way to reach at anticompetitive conduct. That is, what may be immune to remedy through domestic antitrust coverage may be addressed internationally. Because immunities as a form of public restraints are not an issue of overlapping enforcement between domestic and international antitrust institutions, the international setting may be the most effective way to combat immunities.

A WTO solution can only be effective if there is a transformation of the WTO dispute settlement process toward a more economics-based approach incorporating antitrust thinking. This requires the creation of an antitrust tribunal as a first level of WTO adjudication. Appeals should be handled per the traditional route to the WTO Appellate Body. Recall Diagram B, which illustrated the overlap of antitrust and international trade. An effective WTO solution would require a two-level screen of both trade and antitrust inquiries. Successful cases would need to pass both the antitrust screen and the trade screen. That is, for a WTO remedy to apply, the conduct in question would be required to violate both trade-based nondiscrimination and antitrust-based anticompetitive harm. Moreover, a WTO solution ought to address issues of potential overlapping jurisdiction between domestic and international adjudication.

268 See THE WTO, INTEllectual PROPERTY RightS AND THE KNOWLEDGE ECONOMY pt. 1 (Keith E. Maskus ed., 2004) (discussing the example of IP in the WTO context that set a high floor for IP rights); Andrew T. Guzman, International Antitrust and the WTO: The Lesson from Intellectual Property, 43 VA. J. INT'L L. 933, 934 (2003). 
The proposed WTO solution is not an exclusive solution. In conjunction with soft law institutions, it should build domestic capacity to limit or remove public restraints. Hard law solutions are infrequent whereas soft law fosters day-to-day interaction between agencies. Thus, soft law institutions play a critical role in shaping antitrust norms. They can help to identify public restraints, develop better practices to reduce them, and serve to educate regulators and the public at large as to the anticompetitive aspects of public restraints. A soft law solution on its own would be very gradual, and in the near-to-medium term allow a significant amount of anticompetitive conduct to go unchallenged, because of the reluctance to take on significant public restraints due to public choice concerns. The increased use of the WTO would help solve what soft law harmonization and domestic approaches cannot do as effectively in the near-to-medium term-overcome the domestic political process. It is the domestic political process which has created antitrust immunities and anticompetitive public restraints. Thus, revitalizing antitrust regulation and taking action against such restraints may require an international solution.

\section{Modification of the WTO Dispute Settlement System}

As the Canada Wheat case study illustrates, the danger in misapplication of law and economics to an antitrust inquiry at the WTO level is significant. Therefore, an effective WTO solution requires a reformation of how the WTO examines cases that have a public restraints antitrust component. Once created, legal institutions are difficult to reform. ${ }^{269}$ WTO adjudication is fact-intensive and requires the understanding of complex information in a number of potential markets. ${ }^{270}$ The WTO dispute system, as currently conceived, has serious shortcomings with regard to its ability to handle competition-related cases that are fact-intensive and require significant economic analysis. The small number of such cases on the WTO's docket limit opportunities to improve the WTO's adjudicatory ability through experience. These factors lead to low levels of expertise in this area of law and therefore create demand for institutional reform.

A permanent competition policy panel should be set up to adjudicate WTO cases that have a competition claim. Though this would require some expansive changes to WTO decision-making, in other ways this solution would better rein in overly expansive and analytically problematic WTO competition rulings. The WTO Dispute Settlement Understanding ("DSU")

269 Paul B. Stephan, Global Governance, Antitrust, and the Limits of International Cooperation, 38 CORNELL INT'L L.J. 173, 203 (2005).

270 Peter J. Lloyd, Multilateral Rules for International Competition Law?, 21 WORLD ECON. 1029, 1043-44 (1998). 
has made the WTO less diplomatic and more legalistic. ${ }^{271}$ However, the WTO lacks a standard of review. This presents potential pitfalls for WTO dispute settlement adjudication, particularly in competition public restraint settings, where domestic agency decisions that have a rational basis might be overturned.

WTO dispute settlement adjudication involves not merely different interpretations of legal policy and rules, but a number of institutional alternatives. ${ }^{272}$ For example, a WTO panel can be deferential to national regulation and thereby allocate the decision of policy to the national level. Or it could strictly apply WTO provisions as a floor for appropriate conduct, thereby showing no deference to national regulation. Alternatively, it could take a case-by-case approach as to the appropriate level of liberalized trade and competition policy. All of these approaches present potential pitfalls.

Some scholars argue that panelists should not fill in the gaps in WTO agreements because it threatens the political order on which the WTO agreements have been based. ${ }^{273}$ There is the additional danger that activist judges may expand the meaning of particular agreements or draw alternative meanings. WTO case law suggests that gap-filling may already be occurring. Gap-filling in competition public restraints cases may yield welfare-reducing outcomes because it occurs through adjudicators who lack an economics-based approach. ${ }^{274}$ This makes decision-making less predictable and is more likely to lead to errors in reasoning that will lead to badly decided cases.

An institutional choice of WTO-level adjudication must, for competition issues, address institutional weaknesses of WTO adjudication more generally. A supranational entity may increase the costs of decisionmaking. This would serve to diminish the quality of participation and representation by parties. ${ }^{275}$ Global antitrust regulation is another step removed from citizen preferences. As such, a sovereignty transfer to the international

271 Marc L. Busch \& Eric Reinhardt, Transatlantic Trade Conflicts and GATT/WTO Dispute Settlement 2, 17 (Conference on Dispute Prevention and Dispute Settlement, 2002), available at $\mathrm{http}: / / \mathrm{www}$. law.berkeley.edu/files/Busch_and_Reinhardt--Petersmann_Project.pdf.

272 Gregory Shaffer, Recognizing Public Goods in WTO Dispute Settlement: Who Participates? Who Decides? The Case of TRIPS and Pharmaceutical Patent Protection, 7 J. INT'L ECON. L. 459, 459 (2004) (providing how this formulation plays out in the Agreement on Trade-Related Aspects of Intellectual Property Rights Agreement ("TRIPS agreement")).

273 John H. Jackson, The Role and Effectiveness of the WTO Dispute Settlement Mechanism, in BROOKINGS TRADE Forum 2000 179, 204 (Susan Margaret Collins \& Dani Rodrik eds., 2000) ("The dispute settlement system cannot and should not bear the weight of formulating new rules either by filling gaps in the existing agreements or by setting forth norms that carry the organization into totally new territory such as competition policy or labor standards.”). See also John O. McGinnis, The Political Economy of Global Multilateralism, 1 CHI. J. INT'L L. 381, 381 (2000) (developing a model for analyzing and assessing the practices of global multilateralism).

274 Henry N. Butler, The Manne Programs in Economics for Federal Judges, 50 CASE W. RES. L. REV. 351, 352 (1999) (discussing the importance of training the judiciary in economics).

275 Maduro, supra note 211 , at 15. 
level creates democratic legitimacy concerns. ${ }^{276}$ Compounding this increased cost, WTO panelists might be slower to keep up with the latest developments in antitrust law and economics thinking (if they think about these issues at all).

\section{To a New Solution: A WTO Competition Panel}

The fundamental problem that the WTO faces in antitrust public restraints cases is that its generalist adjudicators are ill-equipped (lacking knowledge, experience, and institutional capital) for dealing with complex international antitrust issues. To date, WTO adjudication has led to misguided and inconsistent rulings. ${ }^{277}$ This Article proposes to create a standalone competition panel to address all disputes that raise public restraint issues that directly or indirectly implicate competition policy at the WTO. This panel would also have ancillary and pendent jurisdiction of claims in which one element of the claim addresses competition issues. A premise of effective antitrust is that adjudicators have some level of comfort with economics. ${ }^{278}$ A competition panel would put the term "economic" back into the practice of international economic law.

Specialized panels are not unheard of in the trade context. In some trade agreements, panelists may be chosen for their expertise in a particular area of substantive law. For example, under the NAFTA financial services provisions, parties choose panelists from a special roster of financial services experts rather than a roster of trade law experts. ${ }^{279}$ The presumption behind such treatment is that trade experts may not have a sufficient understanding of a highly technical area of law and regulation.

Because of the weakness of existing WTO dispute resolution, to be effective the WTO requires a permanent panel dedicated to competition policy. To build the case for a permanent competition panel, one must first make the case for permanent panels at the WTO more generally. ${ }^{280}$ There are four basic reasons for WTO permanent panels: to reduce the role of the

276 Robert Howse \& Kalypso Nicolaidis, Enhancing WTO Legitimacy: Constitutionalization or Global Subsidiarity?, 16 GOVERNANCE 73, 74 (2003).

277 Einer R. Elhauge, Does Interest Group Theory Justify More Intrusive Judicial Review?, 101 YALE L.J. 31, 78 (1991) (noting the limitations of generalist courts in regulatory areas).

278 Carlton \& Picker, supra note 121, at 10 ("[W] hile both antitrust and regulation are a mix of economics and politics, antitrust is now organized around an economic core.").

279 David A. Gantz, Government-to-Government Dispute Resolution Under NAFTA's Chapter 20: A Commentary on the Process, 11 AM. REV. INT'L ARB. 481, 485 (2000) (citing NAFTA, Art. 1414(3)).

280 See, e.g., Communication from the European Communities, Contribution of the European Communities and its Member States to the Improvement of the WTO Dispute Settlement Understanding TN/DS/W1 (Mar. 13, 2002) (suggesting that a permanent panel be created to adjudicate all WTO disputes); William J. Davey, The Case for a WTO Permanent Panel Body, 6 J. INT'L ECON. L. 177, 177-78 (2003). 
WTO Secretariat in panel decision-making, to overcome conflicts of current panelists, to prevent exclusion of EU and U.S. panelists, and to increase the quality of decision-making.

Currently, most panelists are full-time trade negotiators. This means that they do not have as much time to spend on their WTO cases as they would if it were their only job. This has become an increasingly significant problem as cases have become either more fact-intensive or have involved questions of first impression (or both). The EC-Biotech Products ${ }^{281}$ panel report, for example, reached 1,050 pages. Complex and document-intensive cases often lead to panelists requesting help from the WTO secretariat staff in summarizing documents. ${ }^{282}$ In pushing the work to the secretariat staff, panelists have ceded some of their authority to a WTO secretariat which may have its own agenda. ${ }^{283}$

The current system allows panelists who may have potential conflicts to adjudicate in such cases. There is not a good system for WTO panelists to disclose any conflicts (actual or potential) when they are chosen for a particular case ${ }^{284}$ Panelists may have to work with disputants the next day on a different matter. Additionally, panelists may, in their full time jobs as trade officials, have conflicts because their home countries may be subject to the same types of claims going forward. ${ }^{285}$

Presently, parties can reject panelists who are citizens of countries in a dispute. This means that often panels exclude potential panelists from the United States, the EU, and Japan. As of 2009, U.S. nationals have been panelists only twelve times out of 444 panelist positions. ${ }^{286}$ In contrast, nearly a third of the 444 panelists used have been nationals of just four countries that are often not parties to disputes: Australia, Canada, New Zealand, and Switzerland. ${ }^{287}$ Problems over selection of panelists have increased in frequency. ${ }^{288}$ This problem also reduces the expediency of WTO adjudication. Because of disagreement over panelists, the WTO staff picks the panelists in over 80 percent of all disputes. ${ }^{289}$ Permanent panelists would prevent some of the most qualified panelists from exclusion from panels.

281 Panel Report, European Communities-Measures Affecting the Approval and Marketing of Biotech Products, WT/DS291, 292, 293/R (Oct. 10, 2006).

282 Scott Miller, Global Dogfight: Airplane Battle Spotlights Power of a Quirky Court-FreeLance Judges at WTO to get Boeing-Airbus Case, WALL ST. J., Jun. 1, 2005, at A1.

283 Alan Wm. Wolff, Problems with WTO Dispute Settlement, 2 CHI. J. INT'L L. 417, 420 (2001).

284 See WTO, Rules of Conduct for the Understanding on Rules and Procedures Governing the Settlement of Disputes ("DSU Rules of Conduct"), art. VI:4 \& Annex 3, WT/DSB/RC/1 (Dec. 11, 1996), available at http://www.worldtradelaw.net/misc/rulesconduct.pdf.

285 Wolff, supra note 283 , at 422.

286 WorldTradeLaw.net Dispute Settlement Commentary, http://www.worldtradelaw.net/dsc/ database/panelistcountrycount.asp (last visited Sept. 26, 2009) (subscription required).

287 Id.

288 Davey, supra note 280, at 178.

289 Miller, supra note 282 , at Al. 
The advantages of a permanent panel would include time saving in organizing a panel.

Under the current DSU, a lack of knowledge of competition policy issues may be overcome as panelists can call on special experts in a field to address particular areas of law. The Understanding on Rules and Procedures allows for the use of experts to assist panels. ${ }^{290}$ Some of the WTO agreements allow for an expert technical group to be assembled, though this has been followed infrequently. ${ }^{291}$

The lack of the use of experts extends to competition cases. In Kodak$F u j i^{292}$ (market access vertical restraints at wholesaler, manufacturer and retail level against foreign photographic film producer), $1916 \mathrm{Act}^{293}$ (antidumping law against importers of products sold below market value), Telmex ${ }^{294}$ (competition barriers to the provision of telecommunications services), and Canada Wheat, the panels did not call upon antitrust experts. Given that these cases are the most competition-like, as some directly implicate competition laws, the inability of panels to appoint competition experts illustrates that in practice such a solution is unviable. Based on the existing cases adjudicated before the WTO, for an institution whose purpose is to reduce barriers to competition, WTO panelists have demonstrated poor reasoning in their competition analysis. Should current WTO panels adjudicate on competition policy issues, outcomes could threaten competition law at a global level through decisions that lack an economic understanding of competition policy. Because of the lack of use of experts, and perhaps the lack of incentives to use experts, a new solution must be fashioned to address how to better define and understand competition issues in WTO decisions.

The idea of a permanent competition panel builds upon earlier scholarship that advocates increased WTO specialization. Andrew Guzman recommends a departmentalized WTO. According to Guzman, such a framework would allow the WTO to better address "trade plus" issues. ${ }^{295}$ Guzman suggests that these departments be modeled after existing WTO Councils,

290 Understanding on Rules and Procedures Governing Settlement of Disputes, art. 13.2, Apr. 15, 1994, Marrakesh Agreement Establishing the World Trade Organization, Annex 2, 33 1.L.M. 1226, 1234 (1994).

291 The expert advice that the WTO panel used in the beef hormone case was done on an ad hoc basis rather than through an expert technical group. David A. Wirth, International Trade Agreements: Vehicles for Regulatory Reform?, 1997 U. CHI. LEGAL. F. 331, 342 n.30.

292 Panel Report, Japan-Measures Affecting Consumer Photographic Film and Paper, ff 5.15.22, WT/DS44/R (Mar. 31, 1998).

293 Appellate Body Report, United States-Anti-Dumping Act of 1916, WT/DS136/AB/R \& WT/DS162/AB/R (Aug. 28, 2000).

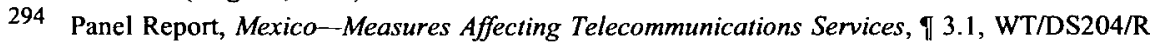
(Apr. 2, 2004).

295 Andrew T. Guzman, Global Governance and the WTO, 45 HARV. INT'L. L.J. 303, 307-08 (2004). 
such as the Council for Trade or the Working Group on Investment. ${ }^{296}$ The present Article extends Guzman's suggestion to advocate for a specialized panel to address competition issues as part of WTO dispute settlement. ${ }^{297}$ The effectiveness of specialized courts over generalized courts in the United States in complex regulatory areas also suggests that such an approach may be valid. ${ }^{298}$ Dispute settlement may be the only way to address issues in which there is a regulatory gap because countries do not have the capacity to effectively challenge public restraints domestically. A competition policy panel for WTO dispute settlement also may limit WTO forumshopping because it would not be possible to recast competition claims as other types of WTO claims.

A competition law standard or approach can only succeed if there is a shared standard among adjudicators. ${ }^{299}$ On substantive issues, previous discussions at the WTO could not come to a substantive agreement on how to address market access issues in which antitrust law interfaced with international trade. ${ }^{300}$ Indeed, the demise of the WTO Trade and Competition Working Group and the OECD Joint Group on Trade and Competition suggests that consensus has yet not been reached on many competition issues as they relate to international trade.

In its design, a competition policy panel mitigates problems of substantive disagreement in antitrust law across jurisdictions. A WTO competition court would adjudicate in two types of situations. In the first situation, competition jurisprudence would review cases in which a national government has adjudicated potential anticompetitive conduct, but where the resulting decision is beyond any justifiable antitrust norm. The second type of case that would fall under the competition court would be when there is immunity from antitrust law at the domestic level. The competition panel would undertake a competition analysis when this behavior otherwise would not be addressed by domestic antitrust institutions. In this second situation, the competition panel would embed a competition-based understanding of economics into a discussion of trade-based non-discrimination. This approach would have competition adjudicators apply economic thinking about industrial organization to the problems of the definition of rele-

\footnotetext{
296 Id. at 307 n.28.
}

297 Guzman, in theory, does not dismiss this possibility. Id. at 321 ("Given the substantial advantage of the WTO over other dispute resolution bodies and the importance of mandatory dispute resolution to the credibility of commitments, there is a strong case for making a dispute resolution body with similar characteristics available to negotiators in a range of regulatory areas." (footnote omitted)).

298 ISAAC UNAH, THE COURTS OF INTERNATIONAL TRADE: JUDICIAL SPECIALIZATION, EXPERTISE, AND BUREAUCRATIC POliCy-MakING passim (1998); Robert M. Howard, Comparing the Decision Making of Specialized Courts and General Courts: An Exploration of Tax Decisions, 26 JUST. SYS. J. $135,221(2005)$.

299 Spencer Weber Waller, Neo-Realism and the Intemational Harmonization of Law: Lessons from Antitrist, 42 U. KAN. L. REV. 557, 573-74 (1994).

300 PHILIP MARSDEN, A COMPETITION POLICY FOR THE WTO passim (2003). 
vant markets and the determination of the exercise of market power as they apply to issues of non-discrimination. ${ }^{301}$

A permanent competition panel would increase expertise on the part of panels in WTO law. This would help to create more nuanced adjudication and increased predictability. The panel would lead to greater certainty as to adjudicatory outcomes. Procedural innovations could also result, as permanent panelists would become repeat players. Ideally, potential competition panelists would already have an antitrust background. Additional expertise would be acquired over time through repeat iterations of cases. Studies examining specialized judges in other areas of law show cause for optimism. For example, a study by Wagner and Petherbridge regarding the success of the U.S. Federal Circuit suggests progress toward bringing consistency and predictability to patent law..$^{302}$

Case understanding is dynamic and can reflect the changing currents in economic thought. The U.S. legal experience in competition jurisprudence is a case study of dynamism that can respond to different situations. William Baxter suggests that provisions for the Sherman Act were broadly drafted by legislative design:

\begin{abstract}
In failing to provide more guidance, the framers of our antitrust laws did not abdicate their responsibility any more than did the Framers of the Constitution. The antitrust laws were written with awareness of the diversity of business conduct and with the knowledge that the detailed statutes which would prohibit socially undesirable conduct would lack the flexibility needed to encourage (and at times even permit) desirable conduct. To provide this flexibility, Congress adopted what is in essence enabling legislation that has permitted a common-law refinement of antitrust law through an evolution guided by only the most general statutory directions. ${ }^{303}$
\end{abstract}

If countries trust their domestic courts to develop an evolutionary understanding of law through precedent, it is possible that a similar precedential understanding may be reached by adjudicators at the international level, especially adjudicators that have specialized knowledge in the field. ${ }^{304}$ This

301 Jonathan B. Baker \& Timothy F. Bresnahan, Economic Evidence in Antitrust: Defining Markets and Measuring Market Power, in HANDBOoK of ANTITRuST ECONOMICS 1, 2-3, 29-32 (Paolo Buccirossi ed., 2008) (providing a formulation of how industrial organization economics may become increasingly judicialized in the United States).

302 See R. Polk Wagner \& Lee Petherbridge, Is the Federal Circuit Succeeding? An Empirical Assessment of Judicial Performance, 152 U. PA. L. REV. 1105, 1156 (2004); Rochelle Cooper Dreyfuss, The Federal Circuit: A Continuing Experiment in Specialization, 54 CASE W. RES. L. REV. 769, 800 (2004).

303 William F. Baxter, Separation of Powers, Prosecutorial Discretion, and the "Common Law" Nature of Antitrust Law, 60 TEX. L. REV. 661, 663 (1982); see also William E. Kovacic, The Modern Evolution of U.S. Competition Policy Enforcement Norms, 71 ANTITRUST L.J. 377, 381 (2003).

304 In the United States, the Supreme Court shows more deference to the decision-making of administrative agencies in case outcomes. Reginald S. Sheehan, Federal Agencies and the Supreme Court: An Analysis of Litigation Outcomes 1953-1988, 20 AM. POL. Q. 478, 486-87 (1992); Harold J. Spaeth \& Stuart H. Teger, Activism and Restraint: A Cloak for the Justices' Policy Preference, in SUPREME 
proposal would help to transform the WTO into a legalized system that has a pro-competition jurisprudence based on sound analysis and economic thinking, rather than one that promotes competitors at the expense of competition. It would help to bridge the gap between trade remedies and antitrust remedies by focusing on direct and indirect immunities from competition which create anticompetitive harm.

A standard objection to this proposal is that we should not expect the WTO to be better suited to understand complex economic analysis than we would national courts. Since national courts do not understand the complexities of public restraints in antitrust, how can we expect the WTO Appellate Body to do better? The response is institutional expertise: a competition policy court would be able to create a better factual record in its decision than would a generalized court. A competition court could go through the nuances of economic thinking better than a court that does not understand competition issues. This also means that a competition court would be better able to weed out bad cases from reaching the Appellate Body. Because of its expertise, the court would establish increased credibility in reaching better reasoned outcomes. ${ }^{305}$ Theoretically, the effectiveness of the competition court might impact the Appellate Body more generally in its thinking or perhaps make the Appellate Body more deferential to the expertise of the competition court.

A competition panel solves a number of concerns regarding WTO accountability, consistency, and predictability. ${ }^{306}$ First, a competition policy panel addresses the consistency and predictability problems by institutionalizing knowledge specific to antitrust questions. Such a panel improves accountability because expert opinion can be overseen by a general appellate body. ${ }^{307}$ Constraints exist on the Appellate Body not to rule in ways that create too much change politically (especially as to powerful countries). Even when the WTO panel and appellate body find that a measure is in violation of WTO rules, countries retain some sovereign control, as they can choose whether or not to remove the barriers that they have erected. Should a country choose to enact changes to a domestic policy, this change

COURT ACTIVISM AND ReSTRAINT 277, 279 (Stephen C. Halpem \& Charles M. Lamb eds., 1982). But see Robert M. Howard, The Supreme Court Says Rules are Rules: Ballard v. Commissioner of Internal Revenue Service, 26 JUST. SYS. J. 219, 221 (2005) (explaining that the Supreme Court showed no deference at all to Tax Court rules and by extension, no deference to Tax Court expertise).

305 Potentially, it may be less likely to accord the same level of authority for the Appellate Body than WTO panels. Lawrence Baum, Specialization and Authority Acceptance: The Supreme Court and Lower Federal Courts, 47 POL. RES. Q. 693, 700 (1994) (finding that the former Court of Customs and Patent Appeals cited the Supreme Court less than generalist federal courts of appeal)

306 On these concerns, see Paul B. Stephan, Courts, Tribunals, and Legal Unification-The Agency Problem, 3 CHI. J. INT'L L. 333, 351 (2002).

307 This type of accountability issue also plays out in the U.S. context, where Article III courts hear appeals from FTC administrative law judge decisions. 
must go through traditional domestic legislative or administrative processes. This allows for input at the domestic level.

And, a ruling against a country does not necessarily mean compliance. Rather, a country could choose to keep its protectionist measure and merely take economic penalties instead. ${ }^{308}$ Countries thus weigh the costs and benefits of protection and determine at the state level whether or not to continue such protectionist policies. Most WTO rulings have created compliance, even by the United States and EU. ${ }^{309}$

Powerful states exert influence in picking Appellate Body members. The United States and EU have an effective veto over any potential Appellate Body member. ${ }^{310}$ This power by carries over into Appellate Body decisions. If too many decisions were to go against the EU or the United States, Appellate Body members understand that the WTO's two major players would call for structural changes to weaken the WTO dispute settlement system. ${ }^{311}$ This same reasoning would hold true for the competition panel. The United States and EU would have effective veto power over members of the panel. As such, panelists would have to meet a baseline on competition policy analysis acceptable to both the EU and the United States. Similarly, competition panelists would understand that any gap-filling on their part would elicit a negative political reaction by the United States and/or EU.

An additional question that a solution must address is how to reduce judicial reach that goes too far into challenging domestic regulation. Because of the adjudicatory nature of WTO dispute resolution, judicial decision-making plays a critical institutional role. Transaction cost economics posits that contracts are incomplete because contracts do not (and cannot) contain all possible contingencies. ${ }^{312}$ Even if contracts could do so, a third party adjudicator must rule on contracts and will lack the same knowledge as the parties. ${ }^{313}$ Much like contracts, WTO agreements are incomplete.

\footnotetext{
308 Jayashree WATAL, INTELlectual PROPERTy RIGHTS IN THE WTO AND DEVELOPING COUNTRIES 49 (2001).

309 Bruce Wilson, Compliance by WTO Members with Adverse WTO Dispute Settlement Rulings: The Record to Date, 10 J. INT'L ECON. L. 397, 397 (2007).

310 Richard H. Steinberg, Judicial Lawmaking at the WTO: Discursive, Constitutional, and Political Constraints, 98 AM. J. INT'L. L. 247, 264 (2004).

311 Id.

312 Oliver Hart, Firms, CONTRACTS, AND FINANCIAL STRUCTURE 4-5, $21-23$ (1995).

313 Id. at 29-55. See also Barak D. Richman \& Jeffrey Macher, Transaction Cost Economics: An Assessment of Empirical Research in the Social Sciences (Duke Law Sch. Faculty Scholarship Series, 2006), available at http://sr.nellco.org/duke_fs/62 (providing a literature review of transaction costs economics).
} 
WTO panelists must fill in the gaps. ${ }^{314}$ As with any adjudicatory body, there is concern that WTO dispute settlement will overreach in its rulings.

To address this concern, it is possible to create a standard of review for competition-related cases that can limit the scope of judicial intervention for cases in which there is a domestic alternative. The only agreement in WTO jurisprudence that includes a specific standard of review is Article 17.6 of the Anti-dumping Agreement ("AD Agreement"). However, under the other trade remedy agreements, and the WTO Agreement on the Application of Sanitary and Phytosanitary Measures ("SPS Agreement") as well, panels and the Appellate Body have developed a standard that, in essence, requires panels to examine the quality of the reasoning of the domestic agency.

The language of Article $\mathbf{1 7 . 6}$ is purposely similar to that of the U.S. Chevron doctrine. ${ }^{315}$ This language was inserted at the end of the Uruguay Round by U.S. negotiators who were concerned that a lack of deference in the WTO Antidumping Agreement would lead to findings against the U.S. antidumping regime. The Chevron doctrine establishes deference on the part of courts to an agency's reasonable interpretation of a statute that may have ambiguity. Statutory ambiguity in this context is seen as a delegation of authority by Congress to an administrative agency to resolve the ambiguity. ${ }^{316}$ In Chevron, the Supreme Court articulated that courts should show deference to agency decision-making because of agency expertise. ${ }^{317} \mathrm{~A}$ Chevron analysis reduces the opportunity for judicial intervention over agency decision-making. ${ }^{318}$

314 Enst-Ulrich Petersmann, Challenges to the Legitimacy and Efficiency of the World Trading System: Democratic Governance and Competition Culture in the WTO, 7 J. INT'L ECON. L. 585, 593 (2004).

315 Chevron, U.S.A., Inc. v. Natural Res. Def. Council, 467 U.S. 837, 844-45 (1984). Chevronstyle deference is less likely to be triggered if someone undertakes a textual approach. In contrast, there will be more cases in which deference is granted if someone looks to legislative history because the types of ambiguity that an agency has will be greater. Antonin Scalia, Judicial Deference to Administrative Interpretations of Law, 1989 DUKE L.J. 511, 521. Political accountability justifies deference to agencies and regulation. By being less deferential, courts face the problem of becoming increasingly political in their decision-making as they rule on administrative issues. Jonathan T. Molot, The Judicial Perspective in the Administrative State: Reconciling Modern Doctrines of Deference with the Judiciary's Structural Role, 53 STAN. L. REV. 1, 5-6 (2000).

316 Under United States v. Mead, 533 U.S. 218 (2001), Chevron has been limited to situations in which an agency's promulgation has the force of law-situations in which an agency interpretation has been promulgated after a public notice and comment period.

317 Chevron, 467 U.S. at 845 ("If this choice represents a reasonable accommodation of conflicting policies that were committed to the agency's care by the statute, we should not disturb it unless it appears from the statute or its legislative history that the accommodation is not one that Congress would have sanctioned." (quoting United States v. Shimer, 367 U.S. 374, 383 (1961))).

318 Some argue Chevron-style deference may be misplaced in the WTO because the context for Chevron deference is different. Steven P. Croley \& John H. Jackson, WTO Dispute Procedures, Standard of Review, and Deference to National Governments, 90 AM. J. INT'L L. 193, 211 (1996). Member 
The Appellate Body examined the deference requirements under Article 17.6 in United States-Hot-Rolled Steel. ${ }^{319}$ In its summary of the requirements of Article 17.6(i), the Appellate Body held that the purpose of panels is the "establishment" and "evaluation" of the "facts" of the investigative body. ${ }^{320}$ The factual determination is not a de novo review; rather, panels must consider "whether, inter alia, the 'establishment' of the facts by the investigating authorities was "proper." "321 In Mexico-HFCS, ${ }^{322}$ the Appellate Body held that two elements must be met with an establishment of the facts. First, there is the fact finding during the investigation. Second, there are the assumptions that national authorities made in connection with their determinations. ${ }^{323}$ This system could be applied to an antitrust context. ${ }^{324}$

The availability of a competition remedy through a specialized competition panel would not overwhelm the WTO dispute resolution system. Very few of the cases that involve Article 17.6 have been brought, though technically there are not really any 17.6 cases. Rather, party brings a claim under a substantive provision of the AD Agreement, and then the 17.6 standard applies. This paucity of cases involving Article 17.6 in itself itself may be testament to the restraint that the WTO has shown in its decision-making. ${ }^{325}$ Countries will only bring Article 17.6 claims that they believe they have a good chance of winning. Of these claims, many will never get beyond the consultation stage. Of those that do make it to the panel stage, nearly half of

countries are not accountable to other countries for their interpretation of a regulation. In contrast, an administrative agency is accountable to its domestic legislature. Id. at 208-10. However, Chevron-style deference serves as a way to formalize WTO commitments by reducing the scope of how a panel can decide and to overrule domestic competition decision-making. The formalization of a standard of deference makes the WTO more rather than less accountable to its members.

319 Appellate Body Report, United States-Anti-Dumping Measures on Certain Hot-Rolled Steel Products from Japan, If 50-62, WT/DS1 84/AB/R (July 24, 2001).

320 Id. 155.

321 Appellate Body Report, Mexico-Anti-Dumping Investigation of High Fructose Corn Syrup (HFCS) from the United States-Recourse to Article 21.5 of the DSU by the United States, If 84, WT/DS132/AB/RW (Oct. 22, 2001). The United States Continued Dumping and Subsidy Offset Act of 2000 limits the introduction of new evidence for the evaluation and establishment of the facts, even when such evidence was available in the public record. United States-Continued Dumping and Subsidy Offset Act of 2000, ๆ 222, WT/DS217, WT/DS234/AB/R (Jan. 16, 2003).

322 Appellate Body Report, Mexico-Anti-Dumping Investigation of High Fructose Corn Syrup (HFCS) from the United States-Recourse to Article 21.5 of the DSU by the United States, I 129, WT/DS132/AB/RW (Oct. 22, 2001).

323 Id. भा 84-85.

324 But see Juscelino F. Colares, Alternative Methods of Appellate Review in Trade Remedy Cases: Examining Results of U.S. Judicial and NAFTA Binational Review of U.S. Agency Decisions from 1989 to 2005, 5 J. EMPIRICAL LEGAL STUD. 171, 192-93 (2008) (arguing that NAFTA Chapter 19 panels have applied a different standard of review than U.S. courts).

325 James P. Durling, Deference, But Only When Due: WTO Review of Anti-Dumping Measures, 6 J. INT'L ECON. L. 125, 127 (2003). 
the dumping decisions come out in favor of the country that imposed the duty. ${ }^{326}$ Only half of the panel decisions are appealed. ${ }^{327}$ Overall, the WTO system under Article 17.6 seems to work and shows adjudicatory restraint. ${ }^{328}$ In the competition panel context, a similar result is possible. Countries would bring a claim based on anticompetitive regulation only if they thought that they had a good chance of winning the case, and only in situations in which there is a clear violation.

The competition panel also would address a second set of cases. In these cases, the panel would decide cases when sector regulation/implied immunities or direct immunities deny a domestic antitrust solution. It would apply an antitrust analysis to cases in which there was no domestic antitrust remedy possible. However, it would only do so in situations in which there was also a violation of non-discrimination. This would solve the problem of poorly-reasoned WTO decision-making, such as Canada Wheat, which rejected an antitrust approach outright and lacked the in-depth analysis of market definition and an abuse of market power that a stand-alone antitrust inquiry would have applied. ${ }^{329}$ The ability to undertake such an analysis assumes the existence of panelists who have the competency of both competition law and international trade law, and who can fashion effective understandings that include both types of analyses. These types of cases do not affect domestic antitrust prosecutorial discretion, because no such domestic discretion exists in cases of immunities. Rather, adjudication at the WTO level for anticompetitive conduct where there is also discrimination merely reformats WTO decision-making to better understand that competition issues are complex and specialized in nature. Thus, the competition panel would address both the non-discrimination issues and the competition issues that overlap with non-discrimination issues.

A key concern that this proposed solution must overcome is the potential that the WTO will impose limitations on domestic antitrust dynamism. Binding international rules may limit the ability of the U.S. to lead by example. ${ }^{330}$ Because WTO commitments are decided by consensus, the large number of countries involved in the WTO increases the costs of the bargaining process. Trade-off is a hallmark of the WTO. In the antitrust setting, WTO membership leads to potentially difficult issues. A number of WTO members lack antitrust laws at all. A WTO solution may lead to a watering down of antitrust law to the lowest common denominator. ${ }^{331}$ If

326 This supports the Priest-Klein theory on litigation outcomes. George L. Priest \& Benjamin Klein, The Selection of Disputes for Litigation, 13 J. LEGAL STUD. 1, 4-5 (1984).

327 Durling, supra note 325 , at 126.

328 Id. at 147.

329 Appellate Body Report, Canada-Measures Relating to Exports of Wheat and Treatment of Imported Grain, I 145, WT/DS276/AB/R (Aug. 30, 2004).

330 McGinnis, supra note 191, at 566.

331 Joel I. Klein, Acting Assistant Att'y Gen., U.S. Dept. of Justice, A Note of Caution with Respect to a WTO Agenda on Competition Policy, Address to The Royal Institute of International Affairs, 
global competition rules are weak, then special interest groups may extract rents on a worldwide scale rather than on a national scale. ${ }^{332}$ Retrenchment of commitments is also possible, as the example of WTO intellectual property commitments under the TRIPS agreement illustrates. The TRIPS experience shows that even with a high level global floor on intellectual property rights, a sufficiently high level of opposition going forward can lead to a retrenchment of commitments. ${ }^{333}$

Such fears may be overblown. With a deferential standard for dispute settlement, U.S. (or any other country's) antitrust dynamism should not be restrained, except in those cases, such as immunities, in which the U.S. antitrust experience should not be emulated. If a U.S. domestic antitrust decision is well-reasoned, there would be no viable WTO case because it would meet the standard of Article 17.6. In cases in which there is no U.S. domestic response because of an inability to reach such conduct, a WTO solution would be the only venue to undertake an analysis and determine appropriate. remedies for the anticompetitive effects of public restraints. Moreover, the goals of antitrust law may change over time based on the level of political and economic development and the openness to the global economy. ${ }^{334}$ The best way to ensure that international antitrust remedies remain dynamic is to create WTO competition policy panelists who can respond to changes in economic thinking and apply such thinking.

The WTO system itself also serves as a check on activist judges. If WTO adjudicators rule in ways that fundamentally alter the political deals forged that underlie the WTO agreements, WTO members would respond by diminishing the power of the WTO dispute settlement process in a future round of agreements. Particularly if rulings decide too often against the interests of both the EU and U.S., these powerful entities will push to rewrite the rules. The U.S. and EU can signal displeasure with WTO rulings through diplomatic statements or through non-compliance. Because of the

(Nov. 18, 1996), available at http://www.usdoj.gov/atr/public/speeches/0998.htm. Even if there were some level of global consensus on substantive issues of antitrust enforcement to promote a common definition of efficiency, other government ministries or the legislatures of certain countries may react against such concems because of other perceived national interests that trump antitrust. See Allan Fels, Competition Policy: Governance Issues-What Are the Alternative Structures? Australia's Experience 3 (2001), available at http:/www.Accc.gov.Au/content/item.phtml?itemId=255475\&nodeld=808alc09 39d5520567dd09697e0f6c0d\&fn=Fels_Canada_20_6_01\%5B1\%5D.pdf (“A competition regime needs to operate in conjunction with other govemment policies. Inevitably, conflict between policies will arise and it will therefore be necessary to determine priorities based on an assessment of national interests.").

332 John O. McGinnis, The Appropriate Hierarchy of Global Multilateralism and Customary International Law: The Example of the WTO, 44 VA. J. INT'L L. 229, 237-38 (2003).

333 See, for example, the decisions by the governments of Thailand and Brazil to break patent protection for essential medicines. Roger Bate, Thailand and the Drug Patent Wars, AEI HEALTH POL'Y OUTLOOK, Apr. 2007, available at http://www.aei.org/docLib/20070404_HPO.pdf.

334 Eleanor M. Fox, Antitrust Law on a Global Scale: Races Up, Down, and Sideways, in REgUlatory COMPETITION AND ECONOMIC INTEGRATION: COMPARATIVE PERSPECTIVES 348, 348-49 (Daniel C. Esty \& Damien Géradin eds., 2001). 
potential costs of judicial overreach, a more formalized adjudicative standard may be devised. With a limited judicial reach and a system that favors big country litigants, even should a competition panel rule against the United States or the EU on claims involving direct or indirect antitrust immunities, these WTO members likely will abide by a WTO decision, as they have more to gain than lose from the WTO system. Such a ruling may serve as the impetus necessary to create legitimacy for change domestically and reduce the scope of public restraints.

A WTO competition panel will be influenced by the U.S. and EU. This will occur directly through likely WTO choices for competition panelists. Indirectly, the United States, EU and other developed countries will play a role in who adjudicates on the panel because most potential panelists will have been trained in the developed world in antitrust law and may accept developed-world approaches on how antitrust regulation may be linked to international trade. This could increase the potential pushback from developing-world countries against the WTO and a competition policy tribunal. It may create a domestic backlash to weaken domestic agencies that already have difficulty in establishing their power and legitimacy. However, these types of concerns are not unique to a competition panel. Rather, these concerns are inherent to the WTO system. Well-reasoned decisions will limit such concerns even in the case of antitrust immunities which may be the most "political" and hence the hardest subject upon which to hope for multilateral consensus.

\section{CONCLUSION}

Anticompetitive public restraints play a distortive role in the global economy. Antitrust immunities are one such case in which public restraints hurt consumers. Though anticompetitive public restraints plague each country, domestic institutions seem ill-equipped to adequately limit these restraints. International institutions can assist domestic antitrust institutions to create better outcomes to address anticompetitive public restraints.

Benchmarking through soft law and bottom-up harmonization based upon domestic approaches on competition advocacy can help domestic institutions to limit some of the effects of public restraints. However, there are limitations to the soft law approach in improving domestic antitrust capacities. Where substantive coordination is difficult, such as with public restraints, binding rules may be the most effective way to address the global nature of the problem. This implicates the WTO as the most appropriate institutional choice to combat public restraints. Because the WTO considers global welfare, the WTO disciplines countries that fail to reduce interna- 
tional spillover and market access policies. ${ }^{335}$ However, the WTO contains significant limitations in its adjudicatory ability to adequately identify and remedy antitrust public restraints.

All institutions have weaknesses, but in the case of public restraints, international hard law through the WTO (properly reformed) can help address these problems in ways that create few domestic overlaps and new distortions of their own. Creating an antitrust panel for WTO antitrust public restraints that would be deferential to domestic antitrust solutions is a first step to improving the adjudicatory capacity of the WTO. Hard law will work with soft law to improve the domestic institutions so that over time, domestic institutions need much less of the international institutions to do this work, because many of the cases will be decided in the shadow of the law. In a world of imperfect alternatives, this proposal has fewer costs and greater benefits than domestic or international soft law solutions.

335 Damien Neven \& Paul Seabright, Trade Liberalization and the Coordination of Competition Policy, in COMPETITION POLICY IN THE GlobAl ECONOMY 381, 399 (Leonard Waverman, William Comanor \& Akira Goto eds., 1997); F.M. SCHERER, COMPETITION POLICIES FOR AN INTEGRATED WORLD ECONOMY 107-08 (1994). 
HeinOnline -- 17 Geo. Mason L. Rev. 190 2009-2010 